ADRIANA FERNANDES PAISANO

\title{
ESTUDO IN VITRO DA AÇÃO ANTIMICROBIANA DE BACTERIÓFAGOS EM CANAIS RADICULARES INFECTADOS POR ISOLADOS CLÍNICOS DE Enterococcus faecalis
}


Adriana Fernandes Paisano

Estudo in vitro da ação antimicrobiana

de bacteriófagos em canais radiculares infectados por isolados clínicos de Enterococcus faecalis

Tese apresentada à Faculdade de Odontologia da Universidade de São Paulo, para obter o título de Doutor, pelo Programa de PósGraduação em Ciências Odontológicas.

Área de Concentração: Endodontia

Orientador: Prof. Dr. Antonio Carlos Bombana

São Paulo 
Catalogação-na-Publicação

Serviço de Documentação Odontológica

Faculdade de Odontologia da Universidade de São Paulo

Paisano, Adriana Fernandes

Estudo in vitro da ação antimicrobiana de bacteriófagos em canais radiculares infectados por isolados clínicos de Enterococcus faecalis / Adriana Fernandes Paisano; orientador Antonio Carlos Bombana. -- São Paulo, 2008. 205p. : fig., tab.; $30 \mathrm{~cm}$.

Tese (Doutorado - Programa de Pós-Graduação em Odontologia. Área de Concentração: Endodontia) -- Faculdade de Odontologia da Universidade de São Paulo.

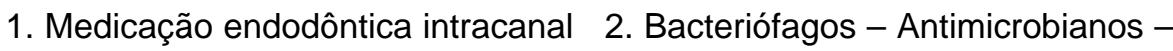
Efeitos 3. Enterococcus faecalis - Canais radiculares

CDD 617.6342

BLACK D24

AUTORIZO A REPRODUÇÃO E DIVULGAÇÃO TOTAL OU PARCIAL DESTE TRABALHO, POR QUALQUER MEIO CONVENCIONAL OU ELETRÔNICO, PARA FINS DE ESTUDO E PESQUISA, DESDE QUE CITADA A FONTE E COMUNICADA AO AUTOR A REFERÊNCIA DA CITAÇÃO.

São Paulo,

Assinatura:

E-mail: 


\section{FOLHA DE APROVAÇÃO}

Paisano AP. Estudo in vitro da ação antimicrobiana de bacteriófagos em canais radiculares infectados por isolados clínicos de Enterococcus faecalis [Tese de Doutorado]. São Paulo: Faculdade de Odontologia da USP; 2008.

São Paulo:

\section{Banca Examinadora}

1) $\operatorname{Prof}(a) . \operatorname{Dr}(a)$.

Titulação:

Julgamento:

Assinatura:

2) $\operatorname{Prof}(a) \cdot \operatorname{Dr}(a)$.

Titulação:

Julgamento: Assinatura:

3) $\operatorname{Prof}(a) . \operatorname{Dr}(a)$.

Titulação:

Julgamento:

Assinatura:

4) $\operatorname{Prof}(a) \cdot \operatorname{Dr}(a)$.

Titulação:

Julgamento: Assinatura:

5) $\operatorname{Prof}(a) . \operatorname{Dr}(a)$.

Titulação:

Julgamento: Assinatura: 
"Não é a carne ou o sangue, é o coração que nos faz pais e fillhos"

Friedrich Schiller

Aos meus pais, Vicente e Yvonne, que sempre estiveram ao meu lado e serviram de forte ponto de apoio para a minha jornada. A minha eterna gratidão. 
"A gratidão é a memória do coração."

Antístenes

\section{AGRADECIMENTOS}

Ao Prof. Dr. Antonio Carlos Bombana, por me permitir compartilhar de seu ilimitado conhecimento científico, orientando de forma segura e objetiva este trabalho, e cujo constante incentivo e apoio foram fundamentais para a sua conclusão, Ihe dedico toda a minha admiração e meu mais profundo agradecimento.

À Profa ${ }^{\mathrm{a}}$ Dr ${ }^{\mathrm{a}}$. Silvana Cai, pela clareza com que transmite seus ensinamentos, amizade e importante colaboração na realização deste trabalho, além de confiar a mim a utilização do Laboratório de Microbiologia Oral, sem o qual este trabalho seria inviável, meus sinceros agradecimentos.

Ao Prof. Dr. Beny Spira, por sua disponibilidade de me conduzir pelo caminho da pesquisa, enriquecendo minha formação com o compromisso pela verdade e precisão científica. Seu trabalho no meio científico é exemplo de dedicação e perseverança. 
À Prof ${ }^{a}$. Dra ${ }^{\mathrm{a}}$. Patrícia Helena Pereira Ferrari, pelas sugestões, orientações e auxílio em todos os momentos da pesquisa, além do prazer de contar com sua experiência e convívio. A sua capacidade como docente vai muito além de qualquer elogio e sua dedicação me surpreende a cada dia.

Ao Prof. Dr. Márcio Braga Lauretti, pelo estímulo e confiança depositada, tornando possível a minha carreira docente. Tê-lo como modelo é natural decorrente da sua conduta pessoal e profissional.

Ao Prof. Dr. Sérgio Toshinori Maeda, pelo incentivo durante a minha jornada discente e docente. Agradeço seus preciosos ensinamentos e os bons momentos de convívio.

Ao Prof. Dr. José Lauriére Horta Guimarães, pelo constante apoio psicológico e científico, que não permitiram que eu desanimasse diante das dificuldades. Como diria Elbert Hubbard, amigo é a pessoa que sabe tudo sobre você, e ainda assim gosta de você. Eu acrescentaria que é também aquele que permanece ao seu lado durante a longa jornada do doutorado. Agradeço pela amizade e paciência.

À Sueli P. Harumi Miyagi, amiga e colega de pós-graduação, que colaborou com seu talento científico e companherismo durante todas as etapas do curso, minha infinita amizade. Uma das alegrias da amizade é saber em quem confiar, e isso eu aprendi com você nesses anos de convívio.

À Prof ${ }^{a}$. Dr ${ }^{a}$. Márcia Martins Marques, pela inestimável ajuda. 
À Mariela E. Burbano Rosero, agradeço pela amizade e ajuda incondicional nunca negada durante as fases experimentais desta pesquisa.

Aos colegas de pequisa Meire Aguena e Gerson Moura Ferreira, pela execução dos experimentos envolvendo a biologia molecular dos fagos e por tantos esclarecimentos feitos durante todo o processo.

À Prof ${ }^{a}$. Dr ${ }^{a}$. Marli Ueda e ao Prof. Jonas José Kisielius, pelos ensinamentos sobre virologia e microscopia eletrônica de transmissão, sempre com cordialidade e atenção.

À Profa ${ }^{a}$. Dra ${ }^{a}$ Marta Maria Antoniazzi e ao técnico Alexsander Seixas de Souza, pela realização das microscopias eletrônicas de transmissão no Instituto Butantan.

Ao técnico Haroldo de Lima Bueno do LELO, pela realização das microscopias eletrônicas de varredura.

À Flávia Belmonte, pela paciência e disposição em me ajudar durante o processo de confecção deste trabalho.

Ao Prof. Dr. Celso Caldeira e colegas do CADE, Carmem, Alexandre, Edson e Wagner, que além de me acolherem como docente, foram sempre compreensivos quanto às minhas ausências. 
Aos colegas do pós-graduação Alexandre, Carmo, Denise e Isabel, agradeço a troca de experiências e o convívio prazeroso.

Aos colegas da Disciplina de Endodontia da Universidade Metodista de São Paulo, que me incentivaram na realização deste trabalho.

Às bibliotecárias Vânia e Glauci, pelo importante auxílio na revisão das normas de redação e apresentação desta tese e aos funcionários do Departamento de Dentística, Ana Maria, David e Sr. Aldo, pelo trabalho sério e profissional.

À Cátia, que sempre colaborou com a organização do pós-graduação.

A todos que participaram direta ou indiretamente desta fase da minha vida.

"A gratidão não nos tira nada, ela é dom em troca, mas sem perda, e quase sem objeto. A gratidão nada tem a dar, além do prazer de ter recebido. Ela é um mistério, não pelo prazer que temos com ela, mas pelo obstáculo que com ela vencemos. É a mais agradável das virtudes, e o mais virtuoso dos prazeres."

A. Comte-Sponville 
Paisano AP. Estudo in vitro da ação antimicrobiana de bacteriófagos em canais radiculares infectados por isolados clínicos de Enterococcus faecalis [Tese de Doutorado]. São Paulo: Faculdade de Odontologia da USP; 2008.

\section{RESUMO}

O uso de diferentes tipos de medicação intracanal para o controle do processo infeccioso, principalmente nos casos em que há presença de microrganismos resistentes às manobras de desinfecção, tem sido alvo de muitas pesquisas. A proposta deste estudo foi avaliar, in vitro, o efeito antimicrobiano de bacteriófagos específicos diante de cinco cepas de Enterococcus faecalis e a ação de um lisado híbrido polivalente na eliminação da infecção causada por essas cinco cepas da mesma espécie. Foram utilizados 37 dentes unirradiculares humanos, recentemente extraídos e de proporções aproximadas. As coroas foram removidas e os canais instrumentados até a lima tipo $\mathrm{K}$ de número 45. Os espécimes foram, então, esterilizados e utilizados em dois experimentos distintos. O primeiro experimento utilizou 25 raízes divididas em cinco grupos de cinco espécimes. Três espécimes de cada grupo foram inoculados com uma das culturas bacterianas e seus fagos correspondentes na proporção 1:1, por um período de três horas a $37^{\circ} \mathrm{C}$, enquanto os outros dois, receberam a cultura de microrganismos ou somente meio de cultura (controle positivo e negativo, respectivamente). No segundo experimento, 11 espécimes receberam um inóculo formado pelas cinco cepas por um período de 10 dias de incubação a $37^{\circ} \mathrm{C}$, com o propósito de manter condições apropriadas para a penetração das bactérias no interior dos túbulos dentinários, e um outro espécime recebeu apenas meio de cultura (controle negativo). Essa penetração foi confirmada 
empregando-se microscopia ótica e eletrônica realizada em dois espécimes. Após o período de incubação, o lisado polivalente, preparado com os cinco fagos, foi aplicado por 24 horas a $37^{\circ} \mathrm{C}$ em 8 espécimes, e os demais preenchidos com meio de cultura (controle positivo e negativo). Alíquotas do interior de todos os canais foram colhidas antes e depois do contato com os fagos e no segundo experimento, também 24 e 48 horas depois, para semeadura e contagem de unidades formadoras de colônia. Os resultados do primeiro experimento mostraram 100\% de redução do crescimento bacteriano nos espécimes que receberam a suspensão de fagos específicos, em comparação a seus respectivos controles positivos, em todos os grupos. No segundo experimento, foi comparado o crescimento obtido após os 10 dias de infecção com aquele posterior a aplicação dos fagos, redução que variou entre $50 \%$ e $100 \%$. Diante desses resultados, conclui-se que os bacteriófagos foram eficazes na diminuição dos microrganismos presentes no interior de canais radiculares e nos túbulos dentinários de dentes humanos.

Palavras-Chave: ação antimicrobiana, medicação intracanal, infecção persistente, fagoterapia, bacteriófago 
Paisano AP. In vitro antimicrobial activity of bacteriophages in root canals infected with clinical isolates of Enterococcus faecalis [Tese de Doutorado]. São Paulo: Faculdade de Odontologia da USP; 2007.

\section{ABSTRACT}

Many studies have investigated different intracanal medications to control infection processes, especially in cases of microbial resistance to disinfection procedures. The purpose of this study was to evaluate the in vitro antimicrobial effect of specific bacteriophages on five isolates of Enterococcus faecalis, as well as the activity of a lysate cocktail in eliminating the infection caused by these bacteria. Thirty-seven recently extracted human teeth of approximately equal size and with single roots were used. The crowns were removed and each canal was prepared using $\mathrm{K}$ files,up to \# 45, and sterile physiological saline. Specimens were then sterilized and used in two separate studies. The first study utilized 25 individual roots divided into five groups of five specimens each. Three specimens of each group were inoculated with one of the bacterial cultures and the corresponding bacteriophage in a proportion of $1: 1$, and incubated for three hours at $37^{\circ} \mathrm{C}$; the other two specimens were inoculated with only the bacterial culture or only the culture medium (positive and negative controls, respectively). In the second study, 11 specimens were inoculated with all five strains and incubated for ten days at $37^{\circ} \mathrm{C}$ in order to allow bacteria to penetrate the interior of the dental tubules, and another one, received just the culture medium (negative control). Penetration into the tubules was confirmed by optical and electron microscopy of two specimens. Following incubation, the lysate cocktail prepared using all five bacteriophages was applied to the other 8 specimens for 24 hours at 
$37^{\circ} \mathrm{C}$, and 2 specimens were filled with the culture medium (positive and negative controls). In the first study, samples were taken from the lumen of all canals before and after contact with bacteriophages; in the second, aliquots were also taken 24 and 48 hours after the bacteria were exposed to the phages. All samples were diluted and plated and the number of colony forming units was counted. In the first study, there was a 100\% reduction in bacterial growth in specimens that received the specific bacteriophage suspension compared to the positive controls within each group. In the second study, after ten days the number of bacteria was reduced by $50 \%$ to $100 \%$ following the bacteriophage application. These results suggest that bacteriophages are effective in reducing the number of bacteria inside the root canal and in the dental tubules of human teeth.

Keywords: antimicrobial activity, intracanal medication, persistent infection, phage therapy, bacteriophage 


\section{LISTA DE FIGURAS}

Figura 4.1 - Câmara de fluxo de ar laminar utilizada na realização dos ensaios.....109

Figura 4.2 - Fotomicrografia de um fago denominado T4, infectando uma célula hospedeira de Escherichia coli, a título de ilustração.

Figura 4.3 - Tubos de ensaio contendo as suspensões de fagos específicos, cuja titulação era de $2 \times 10^{8} \mathrm{ufp} / \mathrm{mL}$, em banho de gelo

Figura 4.4 - Placas de lise obtidas de um dos lisados

Figura 4.5 - Grade de cobre de 300 mesh para microscopia de transmissão 115

Figura 4.6 - Microscópio eletrônico de transmissão Leo-906E 115

Figura 4.7 - Fotomicrografia do fago ATCC, infectando uma célula bacteriana de Enterococcus faecalis (aumento de 18.000x).

Figura 4.8 - Fotomicrografia do fago ATCC. Comprimento do capsídeo 65,44 nm, largura do capsídeo 60,23 nm, comprimento da cauda 179,31 nm, largura da cauda 11,8 nm (aumento de 20.000x) 
Figura 4.9 - Fotomicrografia do fago AD. Capsídeo com ausência do ácido nucléico, sugerindo que houve infecção de uma célula bacteriana hospedeira, ao lado de um fago completo (aumento de 30.000x).

Figura 4.10 - Fotomicrografia do fago AD. Comprimento do capsídeo 131,6 nm, largura do capsídeo 62,26 nm, comprimento da cauda 159,9 nm, largura da cauda $16 \mathrm{~nm}$ (aumento de 18.000x).

Figura 4.11 - Fotomicrografia do fago AND. Comprimento do capsídeo 108 nm, largura do capsídeo 46 nm, comprimento da cauda 154 nm, largura da cauda 7,6 nm (aumento de 30.000x). .118

Figura 4.12 - Fotomicrografia do fago AND. Comprimento do capsídeo 106,19 nm, largura do capsídeo 45 nm, comprimento da cauda 138 nm, largura da cauda 10,4 nm (aumento de 35.000x). 118

Figura 4.13 - Fotomicrografia do fago H. Comprimento do capsídeo 95,12 nm, largura do capsídeo 49,8 nm, comprimento da cauda 101,9 nm, largura da cauda 15,6 nm (aumento de 30.000x). .119

Figura 4.14 - Fotomicrografia do fago H. Capsídeo com ausência do ácido nucléico, sugerindo que houve infecção de uma célula bacteriana hospedeira (aumento de 30.000x) 
Figura 4.15 - Fotomicrografia do fago R. Comprimento do capsídeo 98,37 nm, largura do capsídeo 53,84 nm, comprimento da cauda 128,9 nm, largura da cauda $11,38 \mathrm{~nm}$ (aumento de 30.000x).

Figura 4.16 - Fotomicrografia do fago R. Comprimento do capsídeo 98,37 nm, largura do capsídeo 53,84 nm, comprimento da cauda 128,9nm, largura da cauda 11,38 nm (aumento de 30.000x)

Figura 4.17 - Fotomicrografia do fago R. Observação da cauda longa e flexível de dois fagos $\mathrm{R}$ (aumento de $30.000 \mathrm{x}$ ). 121

Figura 4.18 - Digestão do genoma do fago com enzima DNAse. 124

Figura 4.19 - Digestão do genoma do fago com enzima RNAse 124

Figura 4.20 - Curva de crescimento do Enterococcus faecalis em meio EVA .125

Figura 4.21 - Detalhe do desenvolvimento dos microrganismos, observado pela turbidez do meio EVA, após incubação a $37^{\circ} \mathrm{C}$ por 24 horas 126

Figura 4.22 - Espectrofotômetro utilizado para mensuração de absorvância na padronização e obtenção dos inóculos 
Figura 4.23 - Espécime preparado e impermeabilizado em sua superfície externa com adesivo Araldite corado e, o mesmo, acondicionado em tubo de polipropileno. 130

Figura 4.24 - Esquema ilustrativo do Experimento 1 132

Figura 4.25 - Esquema ilustrativo do Experimento 2 134

Figura 4.26 - Esquema ilustrativo das diluições seriadas e semeadura. .135

Figura 4.27 - Confirmação da infecção dos espécimes do Experimento 2, com inóculo de Enterococcus faecalis. 136

Figura 4.28 - Cortes histológicos da dentina radicular apresentando túbulos dentinários corados, indicando a presença de microrganismos 137

Figura 4.29 - Fotomicrografia mostrando os túbulos dentinários livres de magma (aumento de 2000x) 138

Figura 4.30 - Fotomicrografia apresentando dentina radicular humana infectada por Enterococcus faecalis (aumento de 10.000x). 138

Figura 4.31 - Fotomicrografia apresentando infecção de túbulo dentinário humano infectado por Enterococcus faecalis (aumento de 20.000x)..... 139 
Figura 4.32 - Fotomicrografia apresentando túbulos dentinários de dentina humana infectada por Enterococcus faecalis (aumento de 20.000x) 139

Figura 4.33 - Exemplo de esfregaço de Enterococcus faecalis corado pelo método de coloração de Gram, para confirmação da pureza das culturas $(1000 x)$ 140

Figura 4.34 - Desenvolvimento do Enterococcus faecalis, em placa de Petri contendo ágar TSA, a partir da semeadura de um controle positivo, para contagem das ufc 141

Gráfico 5.1 - Crescimento bacteriano obtido dos controles positivos nos grupos do Experimento 1, após 3 horas da inoculação 144

Gráfico 5.2 - Resultados da Tabela 5.2 (Experimento 2), comparando o crescimento bacteriano detectado nas semeaduras, obtidas dos canais radiculares humanos inoculados com 5 cepas de Enterococcus faecalis (10 dias), após aplicação do lisado híbrido de fagos por um período de 24 horas (ufc/mL). 145 


\section{LISTA DE TABELAS}

Tabela 4.1 - Volumes dos inóculos usados nos espécimes do Experimento 1.......131

Tabela 4.2 - Volumes dos inóculos usados nos espécimes do Experimento 2.......133

Tabela 4.3 - Volumes do preparado de fagos usados nos espécimes do Experimento 2

Tabela 5.1 - Crescimento bacteriano detectado nas semeaduras, obtidas dos canais radiculares de dentes humanos inoculados com Enterococcus faecalis, após aplicação da suspensão de fagos (MOI=1), por um período de três horas

Tabela 5.2 - Crescimento bacteriano detectado nas semeaduras, obtidas dos canais radiculares de dentes humanos inoculados com 5 cepas de Enterococcus faecalis (10 dias), após aplicação da suspensão de fagos por um período de $24 \mathrm{~h}$ (ufc/mL) 


\section{LISTA DE ABREVIATURAS, SIGLAS E SÍMBOLOS}

A. gênero Actinomyces

ATCC American Type Culture Collection

C. gênero Candida

${ }^{\circ} \mathrm{C} \quad$ graus Celsius ou centígrado

CFC cloridrato de ciprofloxacina (30 g) + metronidazol (30 g) + hidróxido de cálcio p.a. (60 mg)

DNA ácido desoxirribonucléico

E. gênero Enterococcus ou Escherichia

EDTA ácido etileno-diamino-tetracético

EDTA - T sal dissódico de EDTA (17 g) + tergensol (qsp 100ml)

F. gênero Fusobacterium

g grama

HMDS hexametildisilazano

IKI iodo iodeto de potássio veiculados em glicerina

K. gênero Klebsiella

L litro

LB meio de cultura Luria-Bertani

M molar

MET microscopia / microscópio eletrônico de transmissão

MEV microscopia / microscópio eletrônico de varredura

MTAD mistura de isômero de tetraciclina (doxiciclina), ácido cítrico e detergente (Tween 80)

mg miligrama 


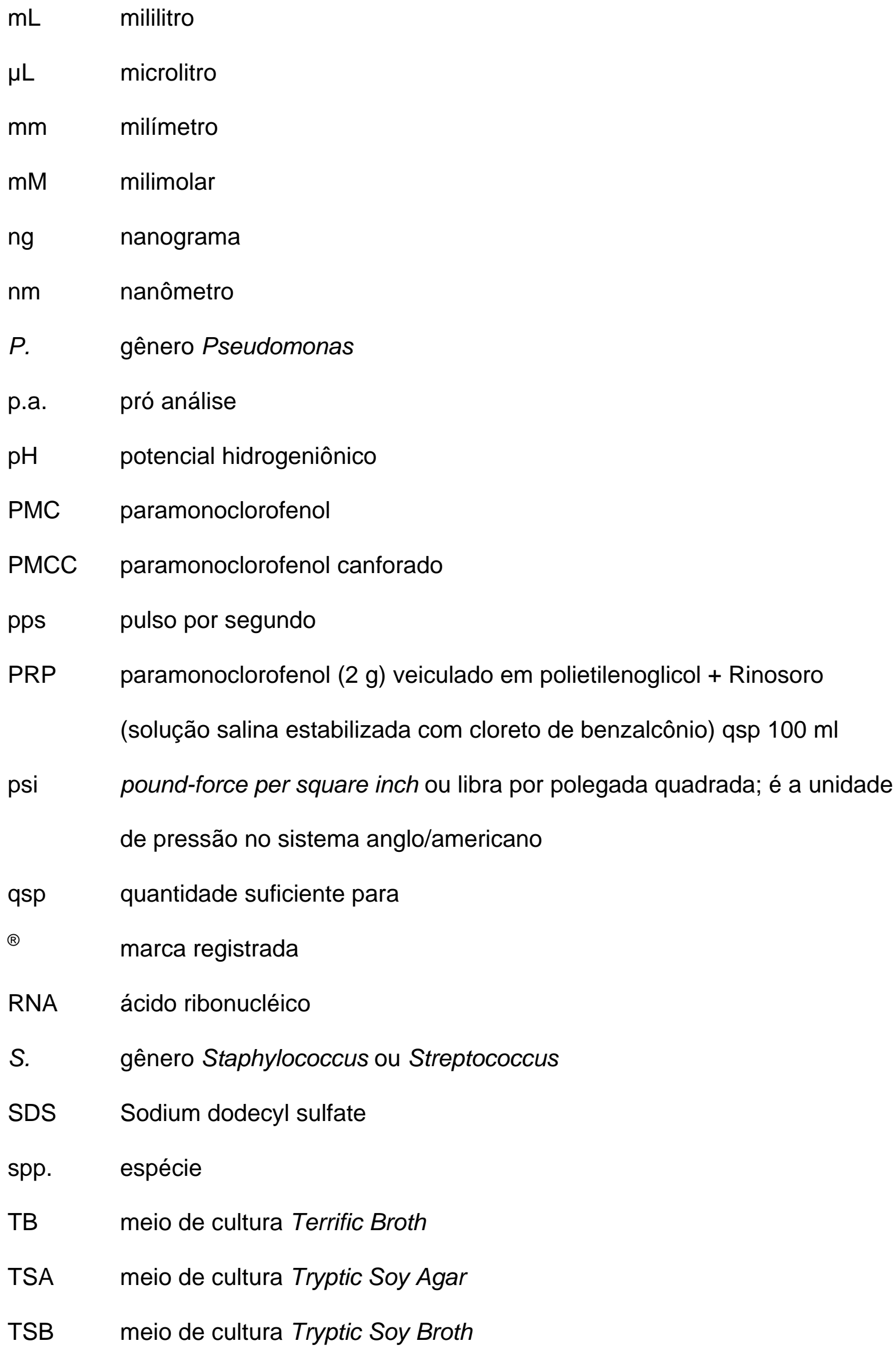


unidades

ufc

unidade formadora de colônia

ufp unidade formadora de placa

UV ultravioleta

$\mathrm{w} / \mathrm{v} \quad$ peso/volume 


\section{SUMÁRIO}

1 INTRODUÇÃO.

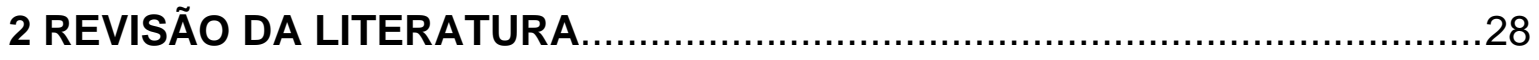

2.1 Microbiologia endodôntica

2.2 Penetração de microrganismos na dentina radicular.............................. 38

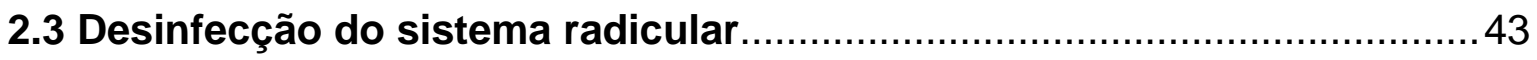

2.3.1 Substâncias químicas auxiliares ao preparo do canal................................. 44

2.3.2 Medicação intracanal de efeito antimicrobiano............................................59

2.4 Microbiota das infecções endodônticas persistentes.............................. 65

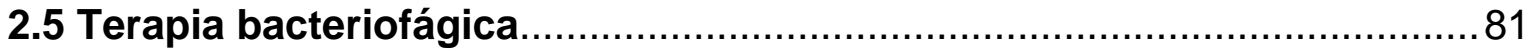

3 PROPOSIÇÃO

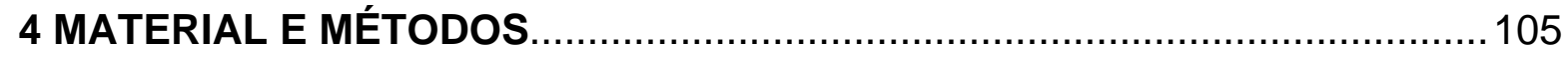

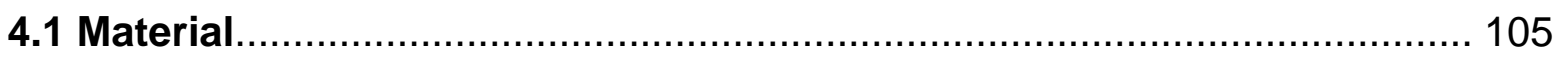

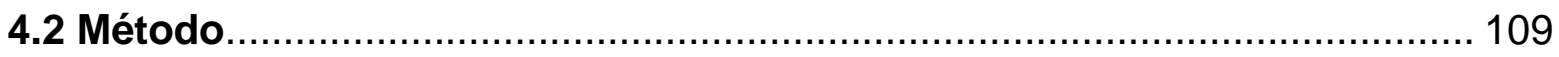

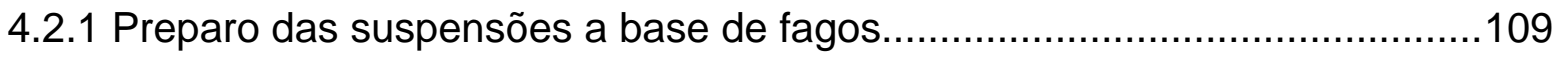

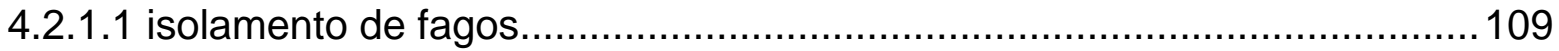

4.2.1.2 titulação da suspensão de fagos....................................................... 112

4.2.1.3 caracterização dos fagos isolados...................................................... 112

4.2.1.3.1 caracterização morfológica macroscópica........................................... 113

4.2.1.3.2 caracterização morfológica microscópica............................................. 113

4.2.1.3.3 caracterização genômica dos fagos..................................................... 121

a - extração do material genético viral................................................121

b - caracterização do material genético do fago......................................122

4.2.2 Curva de crescimento do Enterococcus faecalis em meio EVA................... 125

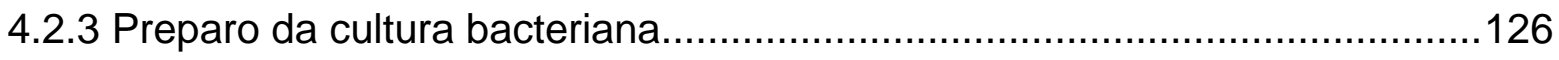

4.2.4 Multiplicidade de infecção e cinética de tratamento com fagos.....................127

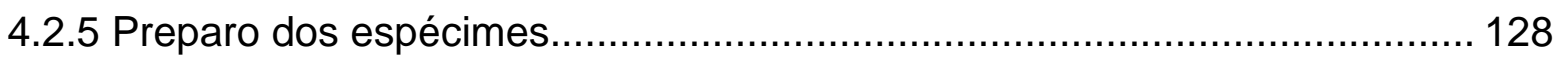

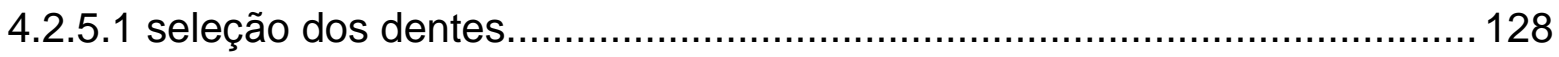

4.2.5.2 seqüência de preparo dos espécimes................................................. 129 


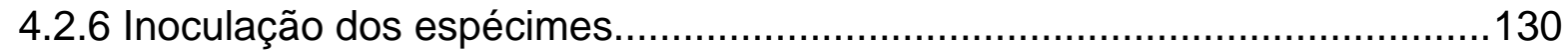

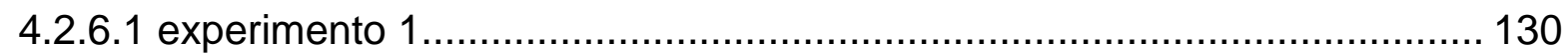

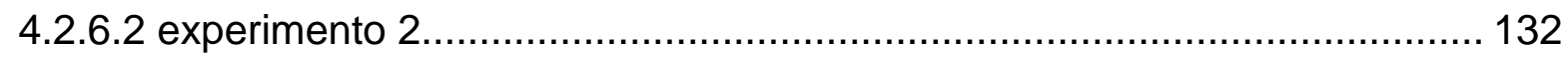

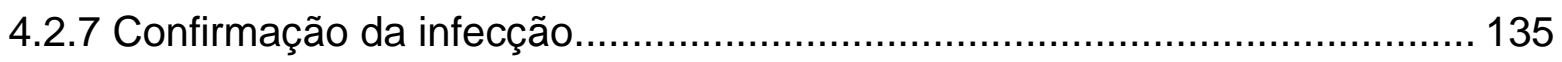

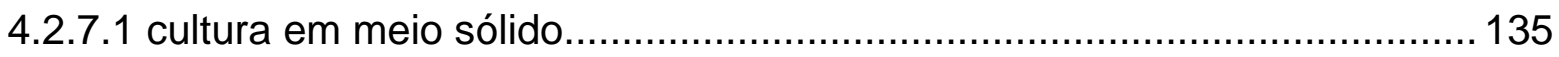

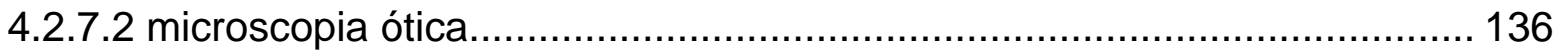

4.2.7.3 microscopia eletrônica de varredura.................................................... 137

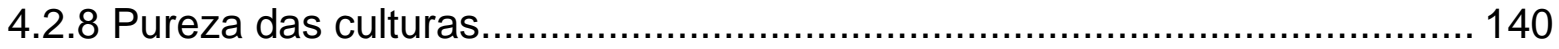

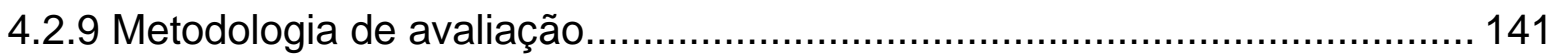

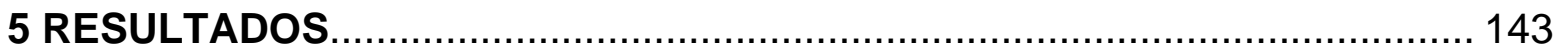

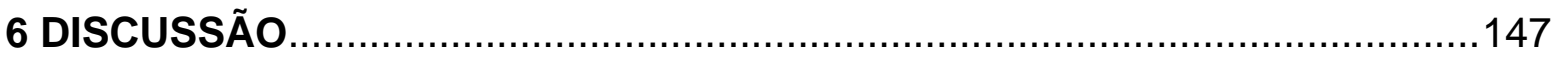

7 CONCLUSÕES

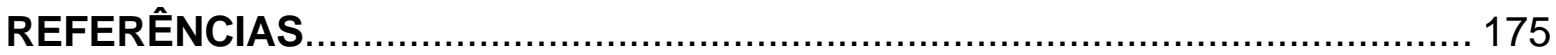

APÊNDICES

ANEXOS 


\section{INTRODUÇÃO}

Um dos objetivos da terapia endodôntica constitui na desinfecção do sistema de canais radiculares. A permanência de grande número de microrganismos viáveis em associação a condições favoráveis a seu crescimento, impede a reparação e, por tal, habitualmente determinam o fracasso do tratamento.

Em estudo desenvolvido por Kakehashi, Stanley e Fitzgerald (1965) observou-se serem microrganismos e seus subprodutos os agentes etiológicos primários da necrose pulpar e da lesão periapical, verificando-se ademais ser característica desses processos infecciosos o perfil polimicrobiano.

Microrganismos que sobrevivem ao preparo químico-cirúrgico, podem rapidamente aumentar em número entre as sessões de tratamento, sinalizando para a utilização de medicações antimicrobianas, principalmente em situações clínicas refratárias aos procederes habituais ou nas reintervenções endodônticas (MOLANDER et al., 1998).

A resistência de microrganismos a ações quimioterápicas compõe problema que vem crescendo dia após dia. Os microrganismos resistentes foram sendo selecionados na proporção em que a prescrição de antibióticos tornou-se indiscriminada, em muito contribuindo para isso os próprios profissionais de áreas de saúde. O uso de antibióticos está indicado para o controle de quadros infecciosos, porém, quando o número de microrganismos resistentes for suficiente para manter a infecção, essa continuará presente (TORTORA; FUNKE; CASE, 2000).

Considerando o atual estágio da questão da resistência de microrganismos aos antibióticos; os - eventualmente elevados — custos de uma terapia com esses 
fármacos; os sempre inconvenientes efeitos paralelos derivados do uso de antibióticos; e, por diversas outras razões, configuraram-se novos interesses pela terapia bacteriofágica.

Os bacteriófagos constituem formas virais que foram descobertas durante 0 período da Primeira Guerra Mundial e, à época, considerados uma esperança para prevenção ou cura de doenças infecciosas. Seu número é estimado em $1 \times 10^{30}$ fagos, sendo, provavelmente, os organismos vivos mais numerosos em nosso planeta. Eles podem ser encontrados nos solos, nas plantas, na água doce ou salgada e nos animais, incluindo o homem (SULAKVELIDZE; MORRIS JR, 2001).

A história da fagoterapia inclui três momentos distintos: o tempo conhecido como era pré-antimicrobianos, a era dos antimicrobianos e a era pósantimicrobianos ou da multirresistência. Na era pré-antimicrobianos, os fagos foram utilizados no tratamento de infecções quase imediatamente após a sua descoberta, compartilhada por dois pesquisadores: Frederick William Twort, em 1915 na Inglaterra, e Felix Hubert d'Hérelle, em 1917 na França. Felix d'Hérelle percebeu que fagos poderiam ser utilizados na clínica médica, criando uma atmosfera de entusiasmo e esperança para o uso no tratamento e profilaxia das doenças bacterianas. Em 1919, ele foi o autor do primeiro relato sobre o uso de fagos no tratamento da disenteria bacilar no homem (GOYAL; GERBA; BITTON, 1987).

A descoberta dos antibióticos a partir da década de 1940 (era dos antimicrobianos) e seu desenvolvimento a partir de então, forçou certo nível de interrupção na pesquisa com fagos. Contudo, estudos das propriedades genéticas básicas desses vírus inauguraram novos segmentos científicos na Microbiologia e noutros setores das ciências médicas como, por exemplo, a Biologia Molecular (GOYAL; GERBA; BITTON, 1987). 
Outras razões foram responsáveis pelo abandono da fagoterapia no Ocidente, incluindo a falta de conhecimento da especificidade entre fago-bactéria, presença de contaminação, resposta imune do hospedeiro com produção de antifagos e falhas nas técnicas laboratoriais empregadas (SULAKVELIDZE; ALAVIDZE; MORRIS JR, 2001).

A terapia bacteriofágica foi tema de publicação científica pela primeira vez em 1933, constando o uso, já a essa época, de produtos a base de bacteriófagos para tratamento de infecções (GOYAL; GERBA; BITTON, 1987).

O uso de fagos no controle da infecção apresenta algumas vantagens. São administráveis em dose única, já que se reproduzem dentro da bactéria alvo e permanecem na região enquanto houver infecção. Os antibióticos, por outro lado, requerem múltiplas doses, dias ou semanas de tratamento (CARLTON, 1999).

Outra grande vantagem reside na ausência de efeitos paralelos e indesejáveis, como a destruição de bactérias úteis ao organismo, ou que competem com bactérias nocivas, o que ocorre muitas vezes com o uso de antibióticos (CARLTON, 1999).

A revitalização da fagoterapia como alternativa terapêutica às infecções bacterianas teve seu início nos anos 80, com experimentos em animais, especialmente desenvolvidos no Reino Unido e pesquisas com fagos aplicados na clínica médica humana, especialmente no Leste europeu.

Por outro lado, embora sendo os fagos altamente específicos para cada espécie de microrganismo, não é totalmente conhecido o quão efetivo seu uso pode ser em cada uma das situações em que poderiam ser empregados como recurso terapêutico. 


\section{REVISÃO DA LITERATURA}

\subsection{Microbiologia endodôntica}

As primeiras observações diretas da presença de microrganismos vivos foram feitas por Antony van Leeuwenhoek, utilizando um microscópio rudimentar, cujas lentes, aperfeiçoadas por ele, eram capazes de observar objetos de mínimo tamanho. As cartas de Leeuwenhoek à Sociedade Real de Londres, em 1683 e em 1695, forneceram descrição clara dos microrganismos encontrados na cavidade oral e eram ilustradas com desenhos precisos dos três padrões morfológicos utilizados ainda hoje na sua identificação: bastonetes, $\operatorname{cocos}$ e formas espiraladas (NISENGARD; NEWMAN, 1997).

Até o final do século XIX, a Endodontia era praticada de forma empírica, uma vez que não se sabia ainda da importância dos microrganismos nas doenças da polpa e do periápice. No entanto, em 1890, Miller introduzia um novo conceito na Endodontia, afirmando que a presença de microrganismos no canal radicular desempenhava importante papel na etiologia das doenças pulpares e periapicais. A partir desse momento, a aspiração dos cirurgiões-dentistas passou a ser o desenvolvimento de um medicamento capaz de destruir todos os microrganismos e resolver o problema dos dentes infectados, inaugurando verdadeira era germicida na Endodontia (LEONARDO; LEAL, 1991).

Em 1894, Miller publicou trabalho sobre patologia de origem bacteriológica, considerado, ainda atualmente, modelo clássico para estudos da microbiota relativa às infecções endodônticas. Na introdução do artigo, o autor afirmou que os aspectos 
bacteriológicos das doenças da polpa e do pericemento certamente não eram compreendidos e que microrganismos deveriam estar, de alguma forma, relacionados a esses processos. Estudou cinqüenta polpas dentais, divididas em quatro diferentes grupos: polpas inflamadas, dentes com câmaras pulpares abertas, polpas necróticas e polpas com conteúdo purulento. Os resultados obtidos a partir da investigação microscópica, nas diferentes condições citadas, mostraram que a grande massa de bactérias viáveis estava presente nas polpas necrosadas e com conteúdo purulento (infecção mista). O autor concluiu o trabalho reiterando a importância do desenvolvimento dessa linha de pesquisa, afirmando que seus experimentos não eram suficientemente avançados para justificar seus resultados. Sendo um dos estudos pioneiros, muitas questões permaneceram sem resposta. Dentre os questionamentos mencionados por ele, um se destaca, podendo e devendo, efetivamente constituir dúvida, mesmo em trabalhos atuais: Temos remédios à nossa disposição capazes de tornar polpas pútridas inócuas ao organismo animal?

Em 1964, o objetivo da investigação feita por Engström foi o de estudar o tipo e a freqüência de enterococos em amostras obtidas de dentes não vitais ou tratados endodonticamente. $\mathrm{O}$ autor utilizou um total de 223 dentes, que foram submetidos à terapia endodôntica convencional. Pesquisou ainda a incidência desse tipo de microrganismo na periferia dos dentes estudados em cada paciente. Foram colhidas amostras bacteriológicas da cavidade pulpar antes e depois de tratamento antiséptico. Amostras dos espaços interproximais e das tonsilas foram obtidas, tanto de pacientes que demonstraram crescimento de enterococos nas amostras iniciais, como de outros, nos quais não houve crescimento. Os resultados mostraram que em $14,9 \%$ das amostras iniciais houve crescimento de enterococos e $65 \%$ desses casos 
não responderam ao primeiro tratamento anti-séptico. A presença de enterococos nos espaços interproximais e tonsilas foi mais freqüente nos pacientes que apresentaram crescimento de enterococos nas amostras iniciais, obtidas dos canais infectados. As cepas de enterococos foram resistentes para: sulfonamida, polimixina e kanamicina. Todas foram sensíveis para: eritromicina e cloranfenicol. Os melhores resultados foram obtidos com a tetraciclina. A pesquisa mostrou que a presença de enterococos não se limita ao interior do canal, mas também ao redor dos dentes, e que há uma correlação direta entre a ocorrência de enterococos na cavidade oral e na cavidade pulpar. $\mathrm{O}$ autor concluiu também que a presença de enterococos nas infecções endodônticas determinava o prolongamento do período de tratamento, devido à dificuldade de eliminação desse tipo de microrganismo.

Wittgow Jr e Sabiston Jr (1975) estudaram dentes hígidos, portadores de polpa necrosada como resultado de trauma. Foram utilizados quarenta dentes, manipulados de forma que não houvesse a possibilidade de contaminação das amostras pela microbiota bacteriana oral. A identificação dos microrganismos, bem como, a sensibilidade a nove tipos de antibióticos foi determinada. Dos quarenta dentes, 32 apresentaram culturas positivas, sendo que em 31 desses havia presença de anaeróbios estritos. Foram isoladas 82 espécies. Nesse estudo, bacilos anaeróbios Gram-negativos estavam presentes em $67 \%$ das amostras totais. A resistência aos antibióticos apareceu em pequena porcentagem, indicando que não houve substancial problema quanto à seleção da profilaxia antibiótica no controle da infecção nesses casos. A presença de patógenos oportunistas em larga proporção, nos casos estudados, mostrou claramente que cuidados devem ser tomados durante a terapia endodôntica para que microrganismos não atinjam a região periapical, originando quadros agudos. 
Em 1982, Fabricius et al. estudaram 24 canais radiculares em macacos. Após os canais serem mecanicamente desvitalizados e expostos à microbiota oral, por uma semana, foram então selados. Os dentes foram observados e amostras colhidas nos seguintes períodos: 90, 180 e 1060 dias. A amostragem final incluía a análise do canal principal, dentina e região apical. O predomínio de bactérias anaeróbias estritas foi de $85 \%$ a $90 \%$, principalmente bacilos Gram-negativos. Foi encontrada uma porcentagem muito baixa de bactérias anaeróbias facultativas, indicando que Enterococcus spp. não participava, significativamente, na indução do processo de infecção periapical primária. Os resultados mostraram que bactérias anaeróbias estritas, como Bacteróides e bacilos anaeróbios Gram-positivos, foram as mais freqüentes e, portanto, envolvidas no desenvolvimento e manutenção das periodontites apicais. Os autores concluíram ainda que a colonização bacteriana difere nas várias regiões dos canais radiculares e, com o passar do tempo, há predominância de bactérias anaeróbias estritas.

Com o objetivo de identificar a ecologia da microbiota do canal radicular infectado e seus determinantes, Sundqvist (1992a) estudou 65 dentes humanos com polpa necrosada e lesão periapical. Os resultados mostraram a presença de bactérias em todos os canais, sendo $90 \%$ composta por anaeróbios. Fusobacterium nucleatum foi a espécie mais prevalente, a qual se apresentava em associação positiva com pelo menos mais quatro espécies bacterianas diferentes: Peptostreptococcus micros, Wolinella recta, Porphyromonas endodontalis e Selenomonas sputigena. O autor observou que a baixa tensão de oxigênio, o suplemento nutricional e a interação bacteriana compõem os principais fatores determinantes dessa ecologia. Ele destacou também o tratamento endodôntico como desestabilizador da microbiota e a medicação intracanal como sendo essencial 
no que diz respeito à eliminação dos anaeróbios, que sobreviveram ao preparo do canal radicular. O estudo mostrou que canais radiculares associados a extensas lesões periapicais apresentaram maior densidade de espécies bacterianas quando comparados a canais portadores de lesões pequenas.

Estudar a relação entre os procedimentos clínicos adotados no tratamento endodôntico e a ocorrência de bactérias entéricas facultativas em canais radiculares infectados foi o objetivo da pesquisa de Sirén et al. (1997). Os tratamentos foram realizados por dentistas clínicos gerais da Finlândia, sendo divididos em dois grupos, segundo o tipo de infecção presente: grupo de bactérias entéricas e grupo de bactérias não-entéricas. Enterococos faecalis foi a bactéria mais isolada no grupo das entéricas, sendo $33 \%$ das amostras em forma de monoinfecção. Os autores também relacionaram o número de visitas e presença de selamento coronário com a detecção dessas bactérias. Bactérias entéricas estiveram presentes em $55 \%$ dos casos nos quais houve a necessidade de remoção do selamento durante a terapia endodôntica, ao passo que, sob essa mesma condição, bactérias não-entéricas estiveram presentes em $30 \%$ dos casos. As bactérias estudadas também foram isoladas em $35 \%$ dos casos de tratamentos que se estenderam por dez sessões ou mais, e também foram detectadas com maior freqüência nos casos de reintervenção endodôntica. Os autores concluíram, com base em seus achados, que o tratamento endodôntico realizado em múltiplas sessões, o selamento inadequado e reintervenções endodônticas aumentam a freqüência de microrganismos resistentes no sistema de canais radiculares.

Sjögren et al. (1997) investigaram o papel da infecção no prognóstico da terapia endodôntica em dentes portadores de lesão periapical e câmara pulpar fechada, tratados em sessão única. Um total de 55 dentes unirradiculares com lesão 
periapical foi instrumentado, irrigado com hipoclorito de sódio a 0,5\% e obturado na mesma sessão. Foram realizadas coletas antes e depois do preparo dos canais e os pacientes foram chamados anualmente, durante cinco anos, para controle. A coleta inicial mostrou que bactérias estavam presentes em $100 \%$ dos canais. Após o preparo do canal, esse número caiu para $40 \%$, sendo $93 \%$ constituído por bactérias anaeróbias. Nos dentes que apresentaram culturas negativas, num total de $94 \%$ houve sucesso da terapia endodôntica. Contudo, a porcentagem de sucesso nos dentes que indicaram culturas positivas foi de $68 \%$. Os resultados mostraram que as dificuldades na avaliação da presença ou ausência de infecção no ato da obturação indicam a importância da eliminação de microrganismos do sistema de canais radiculares, bem como o uso de uma medicação intracanal entre sessões, aumentando as chances de sucesso do tratamento endodôntico.

Le Goff et al. (1997) avaliaram a microbiota de dentes com polpa mortificada, sem lesão cariosa, nos quais tanto a coroa como as raízes estavam intactas. Foi estudada também a suscetibilidade antibiótica da população bacteriana encontrada. Para o estudo, foram utilizados 26 dentes unirradiculares, com alteração cromática e lesão periapical observada radiograficamente. Amostras foram coletadas, isoladas e identificadas. A sensibilidade perante antibióticos foi avaliada por Etest $®$ (análise de halos de inibição). O número de espécies isoladas por dente variou de dois a oito, sendo $81 \%$ de espécies anaeróbias e $19 \%$ facultativas. As mais encontradas foram: Bacteroides gracilis, Propionibacterium acnes, Fusobacterium nucleatum, Prevotella buccae e Eubacterium lentum. Foi testada a sensibilidade de 38 espécies isoladas diante da tetraciclina e amoxicilina combinada com ácido clavulânico. Os resultados mostraram que todas as bactérias testadas foram altamente sensíveis aos 
antibióticos, com concentrações inibitórias mínimas, substancialmente abaixo das concentrações críticas. As espécies isoladas foram mais sensíveis à amoxicilina.

Ferrari, Cai e Bombana (2000) pesquisaram a presença de enterococos, leveduras e enterobactérias em canais radiculares de 11 pacientes adultos portadores de polpa necrótica com câmara pulpar fechada. As amostras foram colhidas com cones de papel absorvente esterilizados, em cinco diferentes tempos: primeira coleta - superfície dental; segunda - imediatamente antes do preparo químico-cirúrgico; terceira - imediatamente após o preparo químico-cirúrgico; quarta - após sete dias sem medicação intracanal e a quinta coleta foi realizada sete dias após a aplicação da medicação intracanal (no caso empregaram o PRP paramonoclorofenol a $2 \%$ associado a Rinossoro e polietilenoglicol 400). Os microrganismos foram isolados em meios de cultura específicos e posteriormente identificados. Enterococos foram isolados em $18 \%$ dos pacientes na segunda coleta e em $36 \%$ após sete dias sem medicação intracanal, reduzindo para $27 \%$ após o uso de medicação. Em apenas um caso houve crescimento de leveduras e enterobactérias. Imediatamente após o preparo químico-cirúrgico, não houve crescimento dos microrganismos pesquisados. Leveduras e enterobactérias foram pouco freqüentes nos casos de infecção endodôntica primária e enterococos mostraram-se resistentes mesmo após o preparo seguido do uso de medicação intracanal.

Dando continuidade à pesquisa de 2000, os mesmos autores, em 2001, investigaram a presença de espécies de enterococos, leveduras e enterobactérias em 25 pacientes portadores de polpa necrótica e lesão periapical com câmara pulpar fechada. As amostras foram colhidas nos seguintes tempos: primeiro - superfície dental; segundo - imediatamente após acessar o canal radicular; terceiro - após 
preparo químico-cirúrgico; quarto - após sete dias sem medicação intracanal e o quinto - sete dias após a inserção da medicação (PRP). As amostras colhidas foram semeadas em meios seletivos e não-seletivos, para então serem identificadas. Em $92 \%$ dos casos, microrganismos puderam ser isolados do interior dos canais na segunda coleta, sendo $16 \%$ enterococos, $4 \%$ enterobactérias e $4 \%$ leveduras. Após o preparo químico-cirúrgico, os oportunistas pesquisados não foram isolados. Após sete dias sem medicação intracanal, $100 \%$ dos canais continham microrganismos, sendo $48 \%$ enterococos, $12 \%$ enterobactérias e $12 \%$ leveduras. Quando foi empregado o PRP por sete dias, enterobactérias e leveduras não foram mais isoladas, enquanto os enterococos foram identificados em três casos. Os autores concluíram que os microrganismos superinfectantes pesquisados foram pouco freqüentes nos casos de infecção endodôntica primária e que os enterococos, especialmente Enterococcus faecalis e Enterococcus faecium, mostraram-se resistentes mesmo após o uso da medicação PRP.

Considerando a importância da presença de microrganismos nos processos patológicos que envolvem o sistema de canais radiculares, Lana et al. (2001) propuseram um estudo para identificar as espécies envolvidas nas infecções endodônticas e também avaliar tanto a efetividade da terapia instituída para combater a infecção, como a suscetibilidade dos microrganismos aos antibióticos testados. Foram analisados microbiologicamente 31 dentes hígidos com polpa necrosada, antes e depois do preparo do canal radicular. Bactérias anaeróbias estritas, anaeróbias facultativas, microaerófilas e leveduras foram isoladas de 24, 14, 5 e 2 espécimes, respectivamente. Os gêneros mais prevalentes foram: Prevotella, Fusobacterium, Lactobacillus, Streptococcus, Clostridium e Peptostreptococcus. No caso das leveduras, as mais freqüentes foram: Candida e Saccharomyces. Os 
resultados mostraram que mesmo após a intervenção endodôntica e aplicação de medicação a base de hidróxido de cálcio, bactérias anaeróbias facultativas puderam ser detectadas em cinco amostras. Apesar desse resultado, os autores observaram que a significante redução da população de microrganismos comprova a efetividade dos procedimentos endodônticos adotados em casos de canais infectados. A maioria das bactérias anaeróbias facultativas foi suscetível à ação dos antibióticos testados. Eritromicina se mostrou ineficaz diante da maior parte das bactérias dos gêneros Veillonella, Peptostreptococcus e Fusobacterium. Os autores observaram ainda que o intensivo uso da tetraciclina, tanto na Medicina como na Odontologia, provocou aumento da resistência das bactérias participantes ou não de processos infecciosos.

A proposta do estudo de Peciuliene et al. (2001) foi determinar a prevalência bacteriana e o papel desempenhado por espécies de Enterococcus spp., bacilos entéricos Gram-negativos e leveduras em canais obturados e portadores de lesão crônica periapical. Foi feita também a avaliação do efeito antimicrobiano do iodo iodeto de potássio usado como solução irrigadora. Foram selecionados para o estudo quarenta dentes com canais obturados e portadores de lesão periapical crônica assintomática. Metade dos espécimes recebeu medicação intracanal a base de hidróxido de cálcio após o preparo do canal radicular, enquanto a outra metade recebeu irrigação final com solução de iodo iodeto de potássio e, em seguida, obturada. Amostras microbiológicas foram colhidas antes e depois do preparo dos canais em ambos os grupos, e uma terceira amostra foi obtida no segundo grupo, após o uso da solução testada. Apresentaram culturas positivas na amostra inicial 33 canais $(82,5 \%)$. Leveduras foram isoladas em seis espécimes, e em três deles havia uma associação com Enterococcus faecalis. Bacilos entéricos (Escherichia coli, 
Klebsiella pneumoniae e Proteus mirabilis) estavam presentes em três dentes, enquanto $E$. faecalis foi isolado em 21 amostras $(63,6 \%)$ das 33 culturas positivas, sendo 11 em forma de monoinfecção. Após o preparo do canal radicular houve crescimento bacteriano em dez dentes, detectado a partir da segunda amostra. $E$. faecalis foi isolado em seis desses casos, sendo que cinco deles em forma de monoinfecção. Apenas uma cultura positiva foi obtida a partir da terceira amostra, colhida depois do uso do iodo iodeto de potássio. Os resultados mostraram que há alta prevalência de bactérias entéricas e leveduras no interior de canais tratados, portadores de periodontite secundária. A espécie mais freqüente foi E. faecalis, observado mesmo após o preparo químico mecânico. O uso do iodo iodeto de potássio mostrou ser efetivo na eliminação de Enterococcus faecalis e Enterococcus faecium, indicando seu uso nas reintervenções endodônticas.

A pesquisa realizada por Sakamoto et al. (2007) mostrou que 50\% das bactérias encontradas nas infecções endodônticas não são cultiváveis, esclarecendo a necessidade do uso de técnicas como a reação em cadeia da polimerase (PCR) e o seqüenciamento de RNA ribossomal (rRNA) na identificação desses microrganismos. Para isso, amostras de 15 dentes, nos quais os canais se apresentavam infectados, foram colhidas em três diferentes momentos: antes de qualquer intervenção (S1), após a instrumentação com hipoclorito de sódio a 2,5\% (S2) e após a instrumentação seguida da aplicação de medicação a base de hidróxido de cálcio e paramonoclorofenol, por um período de sete dias (S3). Todas as amostras foram submetidas às duas técnicas moleculares. Os resultados mostraram que nas coletas $\mathrm{S} 2$ e $\mathrm{S3}$, das 15 amostras estudadas, cinco apresentaram-se livres de microrganismos, enquanto uma significante redução $(99,67 \%$ a $99,85 \%)$ ocorreu nas outras 10 , quando comparadas à S1. Nesse estudo, 
43 diferentes espécies bacterianas foram identificadas, dentre as quais $24(56 \%)$ não cultiváveis. Dezenove dessas 43 espécies foram detectadas mesmo após a terapia endodôntica seguida da aplicação do hidróxido de cálcio com paramonoclorofenol, especialmente as do gênero estreptococos.

\subsection{Penetração de microrganismos na dentina radicular}

Os túbulos dentinários constituem um importante reservatório de microrganismos por meio dos quais a reinfecção pode ocorrer. Nos túbulos dentinários esses microrganismos estão abrigados da ação das soluções irrigadoras e da ação dos instrumentos endodônticos (ØRSTAVIK; HAAPASALO, 1990). Portanto, em casos de canais infectados é indicado o uso de terapias medicamentosas complementares ao preparo químico-cirúrgico, eliminando bactérias que sobreviveram e impedindo sua proliferação.

O objetivo do estudo feito por Shovelton (1964) foi determinar a forma de distribuição bacteriana no interior de dentes sem vitalidade. Foram usados 97 dentes recém-extraídos, sem vitalidade pulpar devido a diferentes etiologias. Dentes com polpas vitais e sem presença de cáries foram usados como controle. Três tipos de secção foram feitos: (a) transversal, desde cervical até terço apical; (b) transversal, somente dentro do terço apical; (c) longitudinal. Cada um dos cortes foi submetido ao teste de coloração de Gram. Os resultados mostraram que dos 79 dentes infectados, 18 não apresentavam contaminação da dentina, 33 apresentavam contaminação leve (um a vinte túbulos invadidos), vinte apresentavam contaminação 
moderada (21 a cinqüenta túbulos invadidos) e oito apresentavam contaminação severa (mais de cinqüenta túbulos invadidos). Quanto à história clínica, os casos agudos somaram 17 dentes contaminados, sendo dez deles com invasão bacteriana da dentina; ao passo que casos crônicos somaram 35 dentes, sendo 26 com invasão bacteriana dos túbulos. Os achados mostraram que a invasão bacteriana da dentina ao redor do canal não ocorreu imediatamente em função da presença de microrganismos. Além disso, nos processos agudos, a invasão bacteriana da dentina não existiu ou foi de caráter leve, controlada mais facilmente quando comparada aos processos crônicos, sob o ponto de vista microbiológico. Diante de processos crônicos, a descontaminação em profundidade mostrou-se necessária, tendo em vista que na maioria dos casos ocorreu a invasão bacteriana dos túbulos dentinários.

Em 1982, Akpata e Blechman estudaram a invasão bacteriana no plano dos túbulos dentinários a partir de um modelo experimental. Os canais radiculares de 14 dentes recém-extraídos foram instrumentados com solução salina e inoculados com bactérias anaeróbias estritas (Bacteroides melaninogeniccus e Peptococcus assacharolyticus) e facultativas (Streptococcus faecalis e Streptococcus sanguis). Após diferentes períodos de incubação a $37^{\circ} \mathrm{C}$, foi feita uma análise relacionando o período de incubação com a invasão bacteriana dos túbulos dentinários. Os resultados mostraram que $S$. faecalis foi o microrganismo que mais penetrou nos túbulos dentinários no período de três semanas, ao passo que, nesse mesmo período, tanto $B$. melaninogeniccus como $P$. assacharolyticus não foram capazes de qualquer invasão. Até a primeira semana, não houve nenhuma invasão por parte de S. faecalis. Esses resultados mostraram que quanto maior o período de tempo de exposição dentinária às bactérias, maior o número de túbulos dentinários infectados e maior a profundidade atingida por esses microrganismos. 
Para que se pudesse investigar in vitro a infecção de túbulos dentinários, Haapasalo e Ørstavik (1987) desenvolveram um modelo de estudo usando cilindros de dentina radicular de incisivos bovinos, obedecendo a padrões morfológicos e dimensionais. Nessa pesquisa, os espécimes foram infectados com Enterococcus faecalis e expostos à ação da pasta de hidróxido de cálcio com paramonoclorofenol canforado. As amostras obtidas da luz do canal foram negativas, enquanto amostras da intimidade da dentina dos mesmos espécimes revelaram infecção por E. faecalis. Os autores concluíram que pesquisas mostrando culturas negativas obtidas apenas da luz do canal principal não definem ausência de infecção, pois microrganismos podem ainda estar presentes e viáveis no interior da massa dentinária.

A proposta de Safavi, Spångberg e Langeland, em estudo realizado em 1990, foi avaliar comparativamente os efeitos antimicrobianos do hidróxido de cálcio e do iodo iodeto de potássio, em dentina radicular humana infectada in vitro por Streptococcus faecium. Os canais foram expostos aos dois agentes antimicrobianos por diferentes períodos de tempo e a viabilidade dos microrganismos foi determinada pela imersão total das raízes em meio de cultura, seguindo-se incubação. lodo iodeto de potássio foi efetivo na descontaminação da dentina em curto espaço de tempo, enquanto o hidróxido de cálcio manteve bactérias viáveis no interior dos túbulos, mesmo quando aplicado por longos períodos. Os autores justificaram o uso do S. faecium, no estudo proposto, por ser esse microrganismo um dos mais resistentes da flora bacteriana do canal radicular (BYSTRÖM; CLAESSON; SUNDQVIST, 1985). Com base nos resultados, os autores sugeriram o uso do iodo iodeto de potássio na irrigação final de canais, onde há suspeita da presença de enterococos. 
Perez et al. (1993) analisaram a migração de três diferentes espécies bacterianas pertencentes à microbiota do canal radicular para o interior dos túbulos dentinários. Para esse experimento foram usados 36 blocos de dentina obtidos a partir de incisivos bovinos, inoculados com Streptococcus sanguis, Actinomyces naes/undii e Prevotella intermedia. O período de coleta das amostras variou entre dez, vinte e 28 dias, sendo metade das amostras observadas com microscopia eletrônica de varredura e a outra metade com microscopia óptica, após os procedimentos histológicos. A análise da penetração mostrou migração do $S$. sanguis em uma profundidade de $792 \mu \mathrm{m}$, enquanto nenhum tipo de migração foi observado em relação às outras duas espécies. Os resultados sugeriram que as diferenças na migração ocorreram devido a fatores morfológicos e tipo de arranjo celular característicos de cada bactéria estudada.

Uma revisão da literatura em relação à microflora presente nos túbulos dentinários foi o alvo do estudo feito por Oguntebi, em 1994. O autor analisou a eficácia do preparo químico-cirúrgico e da medicação intracanal na eliminação de microrganismos, principais causadores do surgimento e perpetuação das lesões periapicais. Na conclusão do trabalho, o autor destacou a importância da desinfecção do canal radicular por meios mecânicos. Afirmou que bactérias não acessíveis pela defesa do hospedeiro ou por agentes antimicrobianos administrados de forma sistêmica devem ser eliminadas por métodos tópicos efetivos, para que ocorra a sanificação do sistema de canais radiculares, nos casos de dentes portadores de necrose pulpar.

O estudo in vitro da invasão de túbulos dentinários por bactérias anaeróbias, normalmente encontradas nas infecções endodônticas, foi o objetivo da pesquisa feita por Siqueira Jr, Uzeda e Fonseca (1996). Os autores inocularam 
Porphyromonas endodontalis, Fusobacterium nucleatum, Actinomyces israelli, Porphyromonas gingivalis, Propionobacterium acnes e Enterococcus faecalis em dentina de incisivos bovinos. Os espécimes foram preparados e observados em microscópio eletrônico de varredura após 21 dias de incubação. A análise dos resultados mostrou que todas as espécies de bactérias foram capazes de infectar a estrutura dentinária. E. faecalis, P. acnes e A. israelli infectaram densamente os túbulos em grande parte de sua extensão, enquanto $P$. gingivalis não demonstrou capacidade de invasão ou colonização dos túbulos (não-dentinofílico). F. nucleatum conseguiu contaminar a parede dentinária, mas não foi capaz de migrar para o interior dos túbulos, formando assim uma espécie de tampão em sua entrada. Os autores atribuíram a diferença de resultados entre as espécies testadas ao tipo morfológico e arranjo celular, confirmando o estudo feito por Perez et al., em 1993.

Waltimo et al. (2000) desenvolveram um modelo experimental para analisar a penetrabilidade da Candida albicans e do Enterococcus faecalis no interior da dentina humana. A penetração foi observada de modo macroscópico, pela turvação do meio de cultura e pelo exame histológico dos túbulos dentinários. E. faecalis penetrou mais rapidamente ( 1 a 5 dias) e em maior profundidade quando comparado à C. albicans, que precisou de até 30 dias para ser visualizada no interior de alguns túbulos dentinários. Os autores atribuíram essas diferenças de penetração ao tamanho das células envolvidas.

O estudo de George, Kishen e Song (2005) avaliou as características do biofilme formado por Enterococcus faecalis e sua penetração nos túbulos dentinários radiculares experimentalmente infectados, sob diferentes condições de crescimento.

Quarenta e cinco molares foram inoculados com E. faecalis ATCC $29212\left(10^{8}\right.$ células), durante 21 dias, e divididos em quatro grupos: 
Grupo 1: espécimes inoculados com a bactéria em meio rico em nutrientes, incubados a $37^{\circ} \mathrm{C}$ em condições de aerobiose.

Grupo 2: espécimes inoculados com a bactéria em meio rico em nutrientes, incubados a $37^{\circ} \mathrm{C}$ em condições de anaerobiose.

Grupo 3: espécimes inoculados com a bactéria em meio sem nutrientes, incubados a $37^{\circ} \mathrm{C}$ em condições de aerobiose.

Grupo 4: espécimes inoculados com a bactéria em meio sem nutrientes, incubados a $37^{\circ} \mathrm{C}$ em condições de anaerobiose.

A análise das imagens obtidas através de microscopia eletrônica de varredura mostrou que o E. faecalis invadiu os túbulos dentinários nas diferentes condições experimentais impostas. A diferença ocorreu em relação à profundidade de penetração das bactérias. E. faecalis penetrou cerca de $1.483,33 \mu \mathrm{m}$ no grupo 1 , 1.166,66 $\mu \mathrm{m}$ no grupo 2, $620 \mu \mathrm{m}$ e $650 \mu \mathrm{m}$ nos grupos 3 e 4, respectivamente.

O estudo deixou expresso que a profundidade alcançada por essa bactéria na massa dentinária é significativamente maior na presença de nutrientes, enquanto que as condições de aerobiose e anaerobiose não mostraram diferenças no seu comportamento invasivo.

\subsection{Desinfecção do sistema radicular}

Atualmente, em função do desenvolvimento de novas técnicas de isolamento, transporte, cultivo e identificação de microrganismos, sabe-se que na grande maioria dos problemas de origem endodôntica existe a participação de agente etiológico 
microbiano (LOPES; SIQUEIRA JR, 1999). Portanto, o maior objetivo no tratamento de canais infectados constitui na eliminação total ou, ao menos, substancial redução no número de microrganismos, prevenindo posterior reinfecção.

O preparo químico-cirúrgico desempenha importante papel na desinfecção, mas não põe o canal radicular infectado em condições ideais para ser obturado. Essa fase do tratamento reduz o número de microrganismos, devendo ser realizada diante da presença de soluções químicas dotadas de propriedades de limpeza e de ação antimicrobiana, com o propósito de atuar sobre a matéria orgânica e sobre microrganismos sabidamente presentes em regiões inacessíveis à ação dos instrumentos endodônticos (LEONARDO; LEAL, 1991).

\subsubsection{Substâncias químicas auxiliares ao preparo do canal}

Microrganismos que penetram na massa dentinária, podem também colonizar a superfície externa do cemento através de túbulos ou canais secundários, sendo capazes de se estabelecerem até mesmo na intimidade de lesões periapicais. Portanto, existe uma necessidade crucial no uso de agentes antimicrobianos que possuam a habilidade de alcançar e eliminar microrganismos tanto do tecido dentinário como do periodontal.

Tradicionalmente, a substância química ideal deve apresentar inúmeras propriedades como lubrificação, degradação de matéria orgânica, biocompatibilidade, baixa tensão superficial, baixa toxicidade, fácil aplicação, entre 
outras. Em relação às infecções endodônticas, todas essas propriedades estão subordinadas a uma de maior importância: a eliminação de microrganismos.

Ørstavik e Haapasalo (1990) investigaram o efeito antimicrobiano de substâncias irrigadoras e de diferentes tipos de medicação intracanal comuns na terapia endodôntica, usando para isso o modelo experimental desenvolvido pelos próprios autores em 1987. Cilindros de dentina radicular bovina foram inoculados com Enterococcus faecalis, Streptococcus sanguis, Escherichia coli ou Pseudomonas aeruginosa. Além do desempenho de cada substância na descontaminação dos túbulos dentinários, foi observada também a velocidade de infecção desses túbulos para cada bactéria. E. faecalis invadiu em dois dias toda a extensão dos túbulos dentinários, enquanto $S$. sanguis necessitou de um período de duas semanas para infecção aceitável como completa. E. coli apresentou baixa capacidade de penetração nos túbulos $(600 \mu \mathrm{m})$, mesmo após longos períodos de incubação. $P$. aeruginosa foi capaz de infectar rapidamente a dentina, mas com baixo número de bactérias. E. faecalis sobreviveu nos túbulos dentinários, na ausência de nutrientes, durante um período superior a sete dias e mostrou-se resistente ao hidróxido de cálcio. E. coli e S. sanguis também resistiram ao hidróxido de cálcio, enquanto $P$. aeruginosa foi rapidamente eliminada (vinte minutos), quando em contato com esse medicamento. O paramonoclorofenol canforado, atuando por volatilização, foi efetivo na eliminação dos quatro diferentes microrganismos, requerendo um tempo de cinco minutos para $S$. sanguis, sessenta minutos para $E$. faecalis, vinte minutos para E.coli e quatro horas para $P$. aeruginosa. Não houve qualquer diferença entre a ação antimicrobiana da solução de hipoclorito de sódio e a solução de clorexidina a $0,2 \%$. O EDTA não mostrou nenhuma ação sobre as bactérias estudadas. 
Comparar a capacidade antimicrobiana e a citotoxicidade de diferentes substâncias irrigadoras foi a proposta da pesquisa de Yesilsoy et al. (1995). Foram testadas as seguintes soluções: hipoclorito de sódio a 5,25\% (controle negativo), a $2,5 \%$ e a $0,5 \%$; Peridex®; gluconato de clorexidina a $0,12 \%$; álcool a $11,6 \%$; Therasol; e soro fisiológico (controle positivo). A parte in vitro do trabalho analisou a ação antimicrobiana de cada irrigante contra Streptococcus mutans, Peptostreptococcus micros, Prevotella intermedia e Porphyromonas gingivalis. Álcool foi ineficaz na eliminação da maioria das bactérias, exceto para o S. mutans. As concentrações decrescentes das soluções de hipoclorito de sódio mostraram efeito antibacteriano também decrescente. Peridex®, gluconato de clorexidina a $0,12 \%$ e Therasol (colutórios) produziram halos de inibição semelhantes ao controle negativo, indicando seu uso alternativo na terapia endodôntica. Os testes in vivo empregaram cobaias, nas quais foi injetada cada uma das soluções. Esses tecidos foram posteriormente removidos e processados para análise histopatológica, decorrido um período de duas horas, dois dias e duas semanas. A maioria das soluções testadas exibiu inflamação suave após duas horas, e um aumento de intensidade após dois dias. Em duas semanas, pôde ser observada inflamação nos tecidos expostos ao hipoclorito de sódio a $5,25 \%$ e a $2,5 \%$, como também ao gluconato de clorexidina a $0,12 \%$. Os autores concluíram que as substâncias testadas apresentaram boa capacidade antimicrobiana e não mostraram toxicidade excessiva, merecendo estudos mais aprofundados para sua aplicação clínica.

A efetividade antibacteriana das substâncias químicas auxiliares é diretamente proporcional à sua capacidade de penetração nos túbulos dentinários infectados (HAAPASALO; ØRSTAVIK, 1987). Por essa razão, em 1997, Berutti, Marini e Angeretti propuseram estudo in vitro do efeito antimicrobiano do hipoclorito 
de sódio usado isoladamente ou combinado com o EDTA acrescido de agente tensoativo (TRITON), durante a instrumentação de canais radiculares. Para o experimento, foram usados 24 incisivos centrais superiores humanos, inoculados com Streptococcus faecalis. Em um dos grupos foi usado hipoclorito de sódio a 5\% seguido de irrigação com EDTA, e neutralização final com soro fisiológico. No outro grupo estudado, a instrumentação foi feita com EDTA seguida de irrigação com agente tensoativo, e imediatamente depois foi feita uma irrigação com hipoclorito de sódio a $5 \%$. Nesse último grupo, a neutralização também foi feita com soro fisiológico. O exame histológico mostrou que no primeiro grupo havia presença de infecção em uma profundidade de $300 \mu \mathrm{m}$ no interior dos túbulos. No segundo grupo, não havia presença de bactérias até $130 \mu \mathrm{m}$ de profundidade, e em alguns cortes não foi encontrado nenhum tipo de infecção. Os autores concluíram que a remoção prévia, pelo EDTA, da camada de magma dentinário e o melhor condicionamento da superfície dentinária pelo agente tensoativo aumentaram significativamente a ação antimicrobiana do hipoclorito de sódio usado durante a instrumentação de canais infectados.

Ayhan et al. (1999) investigaram o efeito antimicrobiano de algumas soluções irrigadoras usadas na terapia endodôntica. Staphylococcus aureus, Enterococcus faecalis, Streptococcus salivarius, Streptococcus pyogenes, Escherichia coli e Candida albicans foram submetidos ao teste de sensibilidade com discos de papel impregnados com solução de hipoclorito de sódio a 5,25\%; hipoclorito de sódio a 0,5\%; gluconato de clorexidina a $2 \%$; álcool a $21 \%$; cresofeno e solução salina. A avaliação da formação de halos de inibição nas placas inoculadas com as espécies testadas fez os autores concluírem que o hipoclorito de sódio a $5,25 \%$ foi a solução mais efetiva na eliminação dos microrganismos, enquanto a solução salina não 
mostrou qualquer efeito. Eles observaram ainda que a diminuição da concentração de hipoclorito de sódio causou significante diminuição da sua capacidade antimicrobiana. Os resultados desse estudo indicaram que a solução de clorexidina foi um irrigante efetivo na eliminação das bactérias testadas, bem como o álcool em concentrações elevadas (21\%). O cresofeno, apesar de suas qualidades antibacterianas e antifúngicas, é citotóxico e um possível agente carcinogênico.

Em 1999, D’Arcangelo, Varvara e Fazio avaliaram a ação de diferentes substâncias irrigadoras usadas no tratamento endodôntico, na eliminação de bactérias facultativas (Candida albicans, Enterococcus faecalis, Escherichia coli, Pseudomonas aeruginosa, Streptococcus mitis, Streptococcus mutans, Streptococcus salivarius e Streptococcus sanguis), estritas (Actinomyces odontolyticus, Fusobacterium nucleatum, Porphyromonas gingivalis e Prevotella melaninogenica) e microaerófilas (Actinobacillus actinomycetemcomitans). As substâncias químicas estudadas foram o hipoclorito de sódio, clorexidina e cetrimida, em diversas concentrações. Cada irrigante foi mantido em contato direto com as espécies bacterianas durante dez, vinte e trinta minutos. Os resultados mostraram que todas as substâncias apresentaram poder bactericida, em todas as concentrações, diante dos microrganismos alvo dos testes.

Devido à presença de bactérias no desenvolvimento de patologias pulpares e periapicais, Siqueira Jr et al. (2000) estudaram in vitro a redução do número de Enterococcus faecalis produzida a partir da instrumentação e irrigação do canal radicular, com hipoclorito de sódio a $1 \% ; 2,5 \% ; 5,25 \%$ e solução salina. Foram feitas culturas de amostras obtidas antes e depois dos preparos. Todas as soluções testadas reduziram o número de bactérias significativamente $(p<0,05)$. Não houve diferença nos resultados no que diz respeito às concentrações de hipoclorito de 
sódio utilizadas. Contudo, essas soluções foram mais efetivas em comparação à solução salina. O estudo mostrou que, apesar de não haver diferença na efetividade do hipoclorito de sódio nas diversas concentrações, valores mais baixos diminuem o tempo de atuação das soluções. Conseqüentemente, se o número de trocas e o volume utilizado for aumentado, no caso de soluções fracas, pode-se conseguir a efetividade antimicrobiana desejada, compensando a baixa concentração. Baseados nos achados, os autores puderam concluir que a necessidade do uso da solução de hipoclorito de sódio em altas concentrações é questionável, pois a mesma efetividade foi obtida através de irrigação copiosa e múltiplas trocas.

Buck et al. (2001) desenvolveram um estudo in vitro comparando a efetividade antibacteriana de três substâncias irrigadoras, no interior de túbulos dentinários humanos. Canais preparados em dentes extraídos e esterilizados, receberam inoculação por Enterococcus faecalis e foram incubados por 12 horas a $37^{\circ} \mathrm{C}$. Cada canal infectado foi exposto a um tipo de substância avaliada por um minuto. Os irrigantes usados foram: hipoclorito de sódio a 5,25\%; EDTA a 0,2\% (Tubulicid) e clorexidina a $0,12 \%$ (Peridex). Água esterilizada foi usada como controle. A presença de bactérias viáveis foi analisada com auxílio de cortes incrementais a partir da luz do canal em direção ao cemento, nos três terços do canal radicular, sendo as raspas então cultivadas. Os resultados mostraram que o hipoclorito de sódio a $0,525 \%$ foi significativamente mais efetivo do que as outras substâncias testadas, enquanto todas mostraram melhor desempenho quando comparadas à água usada como controle. EDTA a 0,2\% mostrou capacidade de amolecer a dentina e remover o magma dentinário, mas foi pouco efetivo quanto à eliminação de bactérias. Clorexidina a 0,12\% mostrou capacidade antimicrobiana semelhante à do EDTA a 0,2\% devido, provavelmente, à baixa concentração em que 
foi utilizada. Os autores concluíram que o efeito bactericida diminuiu e não foi suficiente na desinfecção dos túbulos dentinários quando foram utilizadas soluções em baixas concentrações, ou quando o tempo de exposição aos irrigantes foi demasiadamente curto. Observaram ainda que a profundidade de penetração da bactéria no interior do túbulo dentinário parece ocorrer em todos os terços do canal, e sua desinfecção não é rotineiramente conseguida.

A pesquisa de Ferraz et al. (2001) avaliou tanto a ação antimicrobiana do hipoclorito de sódio a $5,25 \%$, gel de digluconato de clorexidina a $2 \%$ e solução de digluconato de clorexidina a $2 \%$, bem como, a capacidade desses irrigantes na remoção do magma dentinário, in vitro. Foram preparados e inoculados com Enterococcus faecalis, pelo método proposto por Siqueira Jr et al. (1997), setenta dentes recém-extraídos, unirradiculares e com ápice completamente formado. Os achados mostraram que o digluconato de clorexidina a $2 \%$, em forma de gel, produziu a melhor limpeza da superfície dentinária e sua capacidade antimicrobiana foi comparável àquela obtida a partir das outras soluções testadas, indicando o seu uso na terapia endodôntica.

Gomes et al. (2001) estudaram, in vitro, o efeito antimicrobiano de diversas concentrações de hipoclorito de sódio $(0,5 \% ; 1 \% ; 2,5 \% ; 4 \%$ e $5,25 \%)$ e duas formas de gluconato de clorexidina (gel e solução), em três concentrações (0,2\%; $1 \%$ e $2 \%$ ), na eliminação de Enterococcus faecalis. Todos os produtos testados foram efetivos, mas em diferentes períodos de tempo. A solução de clorexidina em todas as concentrações e o hipoclorito de sódio a 5,25\% foram mais rápidos na eliminação do E. faecalis (trinta segundos). Clorexidina gel a $2 \%$ foi efetiva após um minuto de exposição, enquanto essa mesma substância a $0,2 \%$ produziu culturas negativas depois de um período de duas horas. Os resultados mostraram que, apesar de todos 
esses agentes químicos apresentarem atividade antimicrobiana, o período de eliminação da bactéria dependeu tanto da concentração, quanto da forma como as substâncias foram usadas. Os autores enfatizaram ainda que esses dados obtidos in vitro devem ser confirmados com estudos clínicos.

Shabahang e Torabinejad (2003) estudaram o efeito antimicrobiano do MTAD, uma mistura de isômero de tetraciclina (doxiciclina), ácido cítrico e detergente (Tween 80), na desinfecção de 80 canais de dentes humanos previamente infectados com inóculo de Enterococcus faecalis ATCC 4082 (1 x 10 ${ }^{8}$ ufc/mL), por um período de quatro semanas. Após o preparo químico-cirúrgico com hipoclorito de sódio a $1,3 \%$ ou $5,25 \%$, os espécimes foram então divididos em cinco grupos descritos a seguir.

Grupo A: instrumentação com hipoclorito de sódio a 1,3\% e exposição ao MTAD por cinco minutos.

Grupo B: instrumentação com hipoclorito de sódio a 1,3\% e exposição ao hipoclorito de sódio a 1,3\% por cinco minutos.

Grupo C: instrumentação com hipoclorito de sódio 5,25\% e exposição ao hipoclorito de sódio a 5,25\% por cinco minutos.

Grupo D: instrumentação com hipoclorito de sódio a 1,3\% e exposição ao EDTA por um minuto, seguida de hipoclorito de sódio a 1,3\% por cinco minutos.

Grupo E: instrumentação com hipoclorito de sódio a 5,25\% e exposição ao EDTA por um minuto, seguida de hipoclorito de sódio a 5,25\% por cinco minutos.

Tanto a superfície interna como a externa foram expostas aos agentes químicos estudados. No controle positivo foi usada água destilada durante a instrumentação e os espécimes do controle negativo foram autoclavados após a limpeza e modelagem do canal, também realizada na presença de água destilada. 
Raspas de dentina foram obtidas de todos os espécimes para determinar a presença ou ausência de bactérias. O melhor resultado quanto à capacidade antimicrobiana ocorreu no grupo A, no qual a instrumentação foi feita na presença de hipoclorito de sódio a 1,3\%, seguida da aplicação de MTAD por cinco minutos.

Os autores concluíram que apesar do E. faecalis ser resistente à ação sistêmica de antibióticos a base de tetraciclina, o seu uso tópico, sobretudo em altas concentrações como no caso do MTAD, oferece resultados promissores quanto à eliminação de microrganismos resistentes, indicando seu uso na irrigação final dos canais radiculares.

O objetivo da investigação feita por Menezes et al. (2004) foi avaliar in vitro o efeito antimicrobiano dos seguintes agentes no interior de canais radiculares infectados: grupo I, pasta de hidróxido de cálcio em solução fisiológica estéril (SFE); grupo II, PMCC em SFE; grupo III, tricresol formalina em SFE; grupo IV, pasta de hidróxido de cálcio em SFE com PMCC; grupo V, PMCC furacinado em SFE; grupo VI, hipoclorito de sódio a $2,5 \%$ como solução irrigadora; grupo VII, solução de clorexidina a $2 \%$ como solução irrigadora; e grupo VIII, SFE como solução irrigadora (grupo controle).

Canais de dentes extraídos foram infectados com suspensão de Enterococcus faecalis ATCC 29212 e Candida albicans F-72, ajustadas em 1,5 x $10^{8}$ ufc/mL, por um período de 7 dias de incubação a $37{ }^{\circ} \mathrm{C}$. A confirmação do crescimento microbiano foi realizada a partir da coleta de amostras feitas com pontas de papel absorvente do interior dos canais de todos os espécimes. Novas amostras foram obtidas depois da instrumentação e, no caso das diversas variações de medicação intracanal (grupos de I a V), 15 e 22 dias após suas aplicações. $\mathrm{O}$ crescimento foi avaliado também, logo após a instrumentação na presença das 
soluções irrigadoras testadas (grupos de VI a VIII), e 7 dias após seu uso. Os resultados mostraram que a pasta de hidróxido de cálcio com PMCC foi a medicação mais efetiva na eliminação das duas cepas estudadas e a solução de clorexidina a $2 \%$, usada como solução irrigadora, eliminou mais E. faecalis em comparação ao hipoclorito de sódio a 2,5\%. Por outro lado o tricresol formalina mostrou-se significativamente menos efetivo que os outros agentes antimicrobianos, principalmente em relação a C. albicans.

Duas diferentes cepas de Enterococcus faecalis, isoladas de canais obturados apresentando lesões refratárias, foram usadas no estudo realizado por Portenier et al. (2005). A proposta desta investigação foi comparar a suscetibilidade do E. faecalis nas diferentes fases de crescimento bacteriano frente a três substâncias químicas de uso endodôntico. Em curva de crescimento bacteriano, obtida a partir da contagem da população em intervalos de tempo predeterminados, podemos identificar a fase de crescimento exponencial ou log, fase estacionária e fase de morte celular ou declínio. O comportamento antimicrobiano da solução saturada de hidróxido de cálcio em água, digluconato de clorexidina a $0,05 \%$ e hipoclorito de sódio a $0,0001 \%$, foi avaliado em relação a cada uma dessas fases. Um caldo bacteriano de ambas as cepas, ajustado em $5 \times 10^{8} \mathrm{ufc} / \mathrm{mL}$, foi inoculado em tubos contendo as soluções testadas, e alíquotas subtraídas dessa mistura para análise microbiológica após 30 e 60 segundos, 3, 6 e 10 minutos. Os resultados mostraram que as duas cepas isoladas de canais infectados, foram 1000 a 10.000 vezes mais resistentes aos agentes antimicrobianos testados na fase de declínio, em comparação às fases de crescimento e estacionária, sendo eliminadas somente após 10 minutos de exposição. As células bacterianas em fase log foram as mais sensíveis, algumas eliminadas quase imediatamente após a exposição. Portanto, 
além das diferenças anatômicas dos canais, tipo de microrganismos envolvidos na infecção, condições de defesa do hospedeiro e composição das soluções químicas, os diferentes estados fisiológicos do crescimento bacteriano parecem influenciar o efeito antimicrobiano das substâncias químicas usadas durante a terapia endodôntica.

Em 2006, Sena et al. realizaram um estudo comparativo do efeito antimicrobiano de soluções de hipoclorito de sódio a 2,5\% e 5,25\%, e duas formas de gluconato de clorexidina a $2 \%$ (gel e líquida), usadas como substâncias irrigadoras. Para isso, foram usadas cepas de Enterococcus faecalis (facultativo), Staphylococcus aureus, Candida albicans (aeróbios), Porphyromonas intermedia, Porphyromonas endodontalis e Fusobacterium nucleatum (anaeróbios). Os biofilmes de cada cepa foram desenvolvidos separadamente sobre membranas de nitrato de celulose a partir dos inócuos ajustados em $1,5 \times 10^{8} \mathrm{ufc} / \mathrm{mL}$ para os aeróbios e os facultativos, e $3,0 \times 10^{8} \mathrm{ufc} / \mathrm{mL}$ para os anaeróbios (SPRATT et al., 2001). A formação de biofilme foi verificada através de microscopia eletrônica de varredura após 10 dias de incubação a $37^{\circ} \mathrm{C}$. As membranas foram então expostas aos diferentes agentes antimicrobianos por diferentes períodos, que variaram entre 30 segundos, 5, 10, 15, 30 e 60 minutos, com ou sem a agitação mecânica. Em cada um dos grupos, uma membrana foi exposta à solução salina, sendo esse o controle positivo do experimento. Em relação à agitação mecânica, observou-se que a mesma promoveu um aumento da efetividade para todos os agentes antimicrobianos testados, resultando na eliminação mais rápida dos microrganismos. O melhor desempenho foi apresentado pelo hipoclorito de sódio a $5,25 \%$ e solução de gluconato de clorexidina a $2 \%$, que eliminaram todas as cepas em apenas 30 segundos, sob agitação mecânica. No entanto, os microrganismos facultativos e 
aeróbios foram eliminados em tempos significativamente maiores com ou sem a agitação. A agitação mecânica, portanto, aumentou as propriedades antimicrobianas das substâncias químicas testadas, principalmente aquelas em forma líquida e concentrações maiores (hipoclorito de sódio 5,25\% e solução de gluconato de clorexidina a $2 \%)$.

Muitas substâncias químicas usadas na terapia endodôntica apresentam excelentes propriedades antimicrobianas in vitro, diferente de seu desempenho in vivo (PORTENIER et al., 2001). Essa observação levou Portenier et al. (2006) ao estudo da eficácia de soluções químicas na eliminação de duas cepas de E. faecalis (A197A e VP3-80), na presença ou ausência de pó de dentina ou BSA (Bovine Serum Albumin). Foram testadas duas substâncias, o MTAD e o digluconato de clorexidina, em diferentes concentrações. A clorexidina associada ao cetrimide, um surfactante usado para reduzir a tensão superficial na interface dentina-solução, também foi testada. Ambos, MTAD a $100 \%$ e clorexidina a $0,2 \%$, conseguiram eliminar a bactéria alvo em um período de até cinco minutos. O MTAD a 10\% eliminou as bactérias em um período mais longo, que variou entre 20 e 60 minutos, enquanto concentrações mais baixas (1\%) falharam nesse processo mesmo após 1 hora de exposição. A clorexidina se comportou similarmente quando utilizada nas concentrações mais baixas $(0,02 \%$ e $0,01 \%)$. Por outro lado, a combinação de clorexidina e cetrimide conferiu os melhores resultados, eliminando quase instantaneamente as bactérias viáveis. Todas as substâncias químicas testadas apresentaram a capacidade antimicrobiana reduzida na presença de pó de dentina e BSA, retardando o processo de desinfecção, mesmo após 24 horas. A ação antimicrobiana do MTAD em concentrações abaixo de 3,3\% foi completamente inibida na presença do pó de dentina e BSA. Os resultados mostraram ainda, que 
houve uma mínima diferença na suscetibilidade das duas cepas às substâncias químicas testadas.

Baumgartner e Marshall (2007) compararam a capacidade antimicrobiana das combinações de hipoclorito de sódio a 1,3\% e MTAD, com hipoclorito de sódio a $5,25 \%$ e EDTA a 15\%, usadas na irrigação de canais radiculares de dentes humanos infectados com Enterococcus faecalis por 4 semanas. Alíquotas do interior dos canais foram colhidas após a instrumentação e irrigação, realizadas com as associações propostas. Em seguida, após um novo alargamento feito na presença de cada uma das associações, outras amostras foram colhidas para o estudo microbiológico. Os resultados obtidos mostraram diferenças significantes entre os dois grupos. Na primeira coleta houve crescimento em 8 amostras $(40 \%)$ de um total de 20 espécimes, do grupo irrigado com hipoclorito de sódio a 1,3\% combinado ao MTAD, enquanto que no grupo do hipoclorito de sódio a $5,25 \%$ com o EDTA a $15 \%$, nenhum crescimento foi detectado. Na segunda coleta essa diferença se confirmou, observando-se crescimento em dez amostras pertencentes ao grupo do hipoclorito de sódio a $1,3 \%$ e MTAD. Essa investigação mostrou que a associação do hipoclorito ao EDTA promoveu uma desinfecção de alto padrão, ou pelo menos superior ao hipoclorito de sódio associado ao MTAD, que permitiu o crescimento bacteriano em $50 \%$ das amostras estudadas. O MTAD, portanto, não melhorou a capacidade antimicrobiana do hipoclorito de sódio, confirmando que essa propriedade é notadamente melhorada quando se utiliza essa solução em altas concentrações.

O objetivo da investigação feita por Oliveira et al. (2007) foi comparar a atividade antimicrobiana do gel de clorexidina a $2 \%$ com hipoclorito de sódio a 1,5\% e $5,25 \%$. Oitenta pré-molares inferiores humanos foram preparados, autoclavados e 
infectados com monocultura de Enterococcus faecalis, ajustada em 3,0 × $10^{8} \mathrm{ufc} / \mathrm{mL}$, durante um período de 7 dias. Em seguida, todos os canais foram instrumentados na presença de uma das substâncias selecionadas para o estudo. Os espécimes foram divididos em cinco grupos, conforme o tipo de agente antimicrobiano usado durante a instrumentação: gel de clorexidina a $2 \%$ (grupo 1), solução de hipoclorito de sódio a $1,5 \%$ (grupo 2) e solução de hipoclorito de sódio a $5,25 \%$ (grupo 3). Dois outros grupos foram instrumentados com água destilada e gel de natrozol, configurando os grupos controle. Amostras foram coletadas e processadas em três momentos, para contagem de ufc: inicial (antes da instrumentação), após o preparo químico-cirúrgico e final (sete dias depois). A contagem de ufc da segunda coleta (imediatamente após a instrumentação) foi significantemente menor em todos os grupos experimentais, mesmo nos dois controles. Na cultura final observou-se crescimento de E. faecalis nos três grupos experimentais, sobretudo naquele tratado com hipoclorito de sódio a 1,5\%, que não mostrou diferença estatisticamente significante quando comparado aos controles. O estudo confirmou a efetividade antimicrobiana das duas substâncias químicas testadas, principalmente quando usadas em altas concentrações.

O hidróxido de cálcio e a clorexidina têm sido alvo de muitos estudos, principalmente por suas propriedades antimicrobianas, quando utilizados durante a terapia endodôntica. A idéia da associação dessas substâncias e obtenção de um efeito sinérgico, resultando na destruição em largo espectro dos microrganismos, vem crescendo desde 2004 (SIRÉN et al., 2004).

Em recente estudo, realizado por Ercan et al. (2007), os autores testaram a associação da pasta de hidróxido de cálcio $\left(\right.$ Calen $\left.^{\circledR}\right)$ com a solução de clorexidina a $1 \%$ como medicação intracanal, avaliando seu efeito antimicrobiano in vivo. Setenta 
casos de infecção endodôntica refratária aos procedimentos convencionais e portadores de lesões periapicais, foram submetidos a nova instrumentação na presença de solução de clorexidina a $2 \%$, seguida do preenchimento com a associação proposta. A medicação foi trocada a cada seis semanas até que os canais não apresentassem qualquer exsudato ou sintomatologia. $\mathrm{O}$ acompanhamento radiográfico foi realizado trimestralmente para análise da reparação das lesões observadas. A avaliação clínica e radiográfica mostrou que houve cura em $64 \%$, em um período que variou de 6 a 36 meses. Em 14\% houve uma reparação parcial, enquanto que em $22 \%$ as lesões periapicais persistiram.

Os autores concluíram que a associação do hidróxido de cálcio com a clorexidina mostrou-se favorável nos casos de reintervenções associadas à presença de infecções persistentes, sugerindo seu uso como medicação entre sessões.

O estudo realizado por Soares et al. (2007) objetivou mensurar a atividade antibacteriana residual de várias pastas a base de hidróxido de cálcio, após permanecerem em canais radiculares de cães com lesões periapicais crônicas induzidas. Os canais foram instrumentados e preenchidos com quatro diferentes pastas: G1- hidróxido de cálcio com anestésico, G2- Calen ${ }^{\circledR}$ com PMCC, G3Calen $^{\circledR}$, e G4- hidróxido de cálcio com solução de gluconato de clorexidina a $2 \%$. Transcorridos 21 dias, amostras foram recuperadas dos canais radiculares e semeadas sobre ágar com Micrococcus luteus ATCC 9341. Pastas manipuladas e não introduzidas nos canais radiculares serviram como controle. Após pré-difusão, incubação e otimização, as zonas de inibição do crescimento bacteriano foram mensuradas e analisadas. Verificou-se que todas as pastas apresentaram ação antibacteriana residual, com maiores halos para as amostras controle. As médias 
dos halos de inibição para G1, G2, G3 e G4 foram 7,6; 10,4; 17,7; 21,4 mm, respectivamente. Os halos de inibição de G4 foram significativamente superiores aos de G1 e G2. Portanto, independentemente do veículo, todas as pastas a base de hidróxido de cálcio determinaram, em diferentes magnitudes, atividade antimicrobiana residual mensurável. Ademais, diferente do PMCC, a solução de gluconato de clorexidina a $2 \%$ ampliou significativamente a atividade antibacteriana residual do hidróxido de cálcio.

\subsubsection{Medicação intracanal de efeito antimicrobiano}

Byström, Claesson e Sundqvist (1985) realizaram um estudo clínico com o objetivo de avaliar os efeitos antimicrobianos do hidróxido de cálcio, paramonoclorofenol canforado e fenol canforado, usados como medicação intracanal. Os pesquisadores empregaram técnica bacteriológica que podia detectar número muito pequeno de bactérias anaeróbias em 65 dentes unirradiculares e portadores de lesão periapical, tratados em três sessões. Foi demonstrado que a pasta de hidróxido de cálcio (Calasept $\left.{ }^{\circledR}\right)$ possui bom efeito antimicrobiano, superior ao paramonoclorofenol canforado e ao fenol canforado. Dos 35 canais infectados, tratados e medicados com hidróxido de cálcio durante o período de um mês, apenas um deles apresentou bactérias viáveis no seu interior (3\%). Nos dois outros grupos foram encontradas bactérias em dez dos trinta casos estudados (33\%). As bactérias isoladas foram predominantemente Gram-positivas e anaeróbias. Os autores 
destacaram ainda a importância do uso da medicação intracanal na terapia endodôntica de canais infectados.

A proposta do estudo feita por Siqueira Jr e Uzeda (1996) foi a de comparar a capacidade antimicrobiana da pasta de hidróxido de cálcio preparada com dois veículos diferentes: solução salina e paramonoclorofenol canforado. Cilindros de dentina bovina foram experimentalmente infectados com Actinomyces israelli, Fusobacterium nucleatum ou Enterococcus faecalis. E. faecalis é um anaeróbio facultativo que mostra resistência quando exposto ao hidróxido de cálcio, e, por essa razão, os autores optaram por adicionar paramonoclorofenol canforado à sua composição. Os espécimes inoculados foram expostos às duas misturas por período de uma hora, um dia e uma semana. Decorrido o tempo de exposição determinado, os espécimes foram incubados em meio de cultura para posterior avaliação da viabilidade das bactérias e capacidade de desinfecção dos túbulos dentinários. A pasta de hidróxido de cálcio com paramonoclorofenol canforado foi efetiva após o período de uma hora de exposição, exceto no caso do E. faecalis, que necessitou do período de um dia. Por outro lado, hidróxido de cálcio com solução salina não foi capaz de eliminar E. faecalis e F. nucleatum, mesmo quando essas espécies foram expostas por um período de uma semana. Os resultados mostraram que houve um aumento do efeito antimicrobiano quando o paramonoclorofenol canforado foi adicionado ao hidróxido de cálcio.

Os mesmos autores, em 1997, avaliaram a atividade antibacteriana de medicações que atuam por contato, através do teste de difusão em ágar. As medicações testadas foram: clorexidina gel a $0,12 \%$; metronidazol gel a $10 \%$; hidróxido de cálcio com água destilada; hidróxido de cálcio com paramonoclorofenol canforado e hidróxido de cálcio com glicerina. As placas foram inoculadas com 
bactérias anaeróbias estritas (Porphyromonas endodontalis, Porphyromonas gingivalis, Actinomyces israelli, Porphyromonas acnes e Campylobacter rectus) e bactérias anaeróbias facultativas (Staphylococcus aureus, Streptococcus salivarius, Streptococcus mutans, Streptococcus sanguis, Enterococcus faecalis e Actinomyces viscosus). Os achados mostraram que a pasta de hidróxido de cálcio com paramonoclorofenol canforado, bem como, a clorexidina gel a $0,12 \%$ foram efetivas na eliminação de todas as espécies bacterianas testadas. Metronidazol provocou a inibição do crescimento bacteriano de todas as bactérias anaeróbias estritas, enquanto o hidróxido de cálcio com água destilada ou glicerina não apresentou qualquer halo de inibição devido, muito provavelmente, à dificuldade de difusão desses compostos em ágar.

Siqueira Jr e Uzeda (1998) avaliaram a influência de três veículos no desempenho da atividade antimicrobiana da pasta de hidróxido de cálcio: solução salina, glicerina e paramonoclorofenol canforado com glicerina. Os testes foram feitos com bactérias usualmente presentes nas infecções endodônticas: Porphyromonas endodontalis, Prevotella intermedia, Streptococcus sanguis e Enterococcus faecalis. Houve a comprovação do efeito antimicrobiano de todas as pastas testadas, variando apenas o tempo decorrido. A pasta de hidróxido de cálcio com paramonoclorofenol canforado mostrou maior rapidez na eliminação das espécies bacterianas em comparação com as demais associações (uma hora).

O alvo da pesquisa de Trope, Delano e Ørstavik (1999) foi avaliar a cura radiográfica em dentes com lesão periapical tratados em uma ou duas sessões, sendo aplicada ou não medicação intracanal anti-séptica. O primeiro grupo sofreu tratamento endodôntico em sessão única. No segundo grupo, foi realizado o preparo do canal radicular sem aplicação de medicação intracanal. No terceiro grupo, foi 
realizado o preparo do canal e aplicação de hidróxido de cálcio por uma semana. Os três grupos foram avaliados 52 semanas após o término de cada tratamento. 0 terceiro grupo apresentou $81 \%$ de cura radiográfica, enquanto o segundo grupo apresentou apenas 54\%. De acordo com os resultados do estudo, os autores afirmaram que manter o canal radicular preparado sem o uso de uma medicação intracanal é claramente o pior método de tratamento. A aplicação do hidróxido de cálcio aumentou em $10 \%$ o índice de cura radiográfica, diminuindo a possibilidade de recolonização no caso de canais radiculares infectados.

Gomes et al. (1999) estudaram a susceptibilidade de microrganismos aeróbios facultativos e anaeróbios ao hidróxido de cálcio, associado a clorexidina em diversas concentrações, e ao paramonoclorofenol. Os resultados mostraram que o Enterococcus faecalis foi o microrganismo mais resistente. Os autores ressaltam nesse estudo, a necessidade do uso de uma medicação intracanal de amplo espectro, como complemento, visando à descontaminação dos canais radiculares.

Haapasalo et al. (2000) investigaram se a presença de dentina participa na inibição da atividade antimicrobiana de medicações comumente aplicadas no canal radicular. O modelo experimental desenvolvido pelos autores usou pó de dentina esterilizado em autoclave, e posteriormente inoculado com Enterococcus faecalis. Foi testada a atividade antimicrobiana dos seguintes agentes: solução saturada de hidróxido de cálcio em água, hipoclorito de sódio a 1\%, acetato de clorexidina a $0,5 \%$ e $0,05 \%$ e iodo iodeto de potássio em $2 / 4 \%$ e $0,2 / 0,4 \%$. A dentina mostrou efeito inibitório para a capacidade antimicrobiana de todas as substâncias testadas. Hidróxido de cálcio não mostrou nenhuma atividade antimicrobiana sobre E. faecalis. lodo iodeto de potássio se comportou similarmente. Tanto a clorexidina, como o hipoclorito de sódio, tiveram sua capacidade antimicrobiana reduzida, mas não 
eliminada. Os autores concluíram que esse modelo parece eficiente para estudos que envolvam medicação intracanal tópica em Endodontia.

Enterococcus faecalis mostra resistência intrínseca e adquirida a vários antibióticos, participando como agente etiológico no insucesso da terapia endodôntica. Por essa razão, Lima, Fava e Siqueira Jr (2001) propuseram-se a avaliar a efetividade de medicações a base de clorexidina e antibióticos na eliminação do biofilme formado por essa bactéria. Foram utilizados filtros constituídos de membrana de nitrato de celulose na indução da formação do biofilme. Decorrido o espaço de tempo de um dia e de três dias, as membranas contendo o biofilme foram completamente cobertas com 1,0 mL de cada substância testada, sendo o conjunto incubado por um dia a $37^{\circ} \mathrm{C}$. Dentre todas as medicações testadas, apenas aquela a base de clorexidina a $2 \%$ (em forma de gel) foi efetiva na eliminação do biofilme de um dia e de três dias. A associação de clindamicina e metronidazol resultou na redução significativa do número de células bacterianas do biofilme de um dia. Os resultados apontaram a clorexidina como importante agente antimicrobiano em casos de infecções endodônticas refratárias aos tratamentos convencionais.

Distel, Hatton e Gillespie (2002) estudaram a capacidade de formação de biofilme por Enterococcus faecalis em 46 dentes extraídos medicados com hidróxido de cálcio. A análise, pela microscopia eletrônica de varredura e a microscopia confocal, revelaram que essa bactéria foi capaz de colonizar canais medicados com hidróxido de cálcio em períodos que variaram de 2 a 160 dias. A capacidade dessa bactéria em organizar-se em biofilme na superfície interna dos canais radiculares foi observada em ambos os grupos. A microscopia de varredura mostrou colônias de $E$. faecalis embebidas por polissacarídeo extracelular e que a fina espessura desse 
biofilme estava diretamente relacionada com o espaço restrito do canal radicular. Em período de tempo mais tardio, a microscopia confocal permitiu observar canais de água na matriz. Os autores mostraram evidências da colonização do $E$. faecalis em biofilme, arquitetura essa que poderia contribuir para explicar a capacidade desse microrganismo sobreviver em ambiente tão hostil.

Eliminar Enterococcus faecalis do interior dos túbulos dentinários, valendo-se de medicamentos de uso intracanal, foi o objetivo de Lynne et al. (2003). Os autores utilizaram o modelo de dentina bovina proposto por Haapasalo e Ørstavisk (1987), empregando o E. faecalis como microrganismo teste. Os resultados evidenciaram que todas as três medicações foram capazes de se difundir para o interior da dentina e produzir seu efeito antimicrobiano. O hidróxido de cálcio a $10 \%$ foi o mais efetivo contra a bactéria testada em todas as profundidades da dentina. Quando essa medicação foi combinada com Peridex ${ }^{\circledR}$ (gluconato de clorexidina 0,12\%), apesar de o pH alcançado ter sido semelhante ao da formulação do hidróxido de cálcio $10 \%$, foi menos efetiva. Os autores acreditaram que a clorexidina reduziu a atividade antimicrobiana do hidróxido de cálcio por afetar suas propriedades químicas e físicas, sugerindo novos estudos para elucidar os mecanismos responsáveis por essa redução de efetividade.

Os diversos tipos de medicação intracanal atualmente utilizadas nos casos de canais infectados, muitas vezes apresentam dificuldades na eliminação de certos grupos de bactérias. Hoje as pesquisas justificam o uso de uma medicação intracanal com efeito antimicrobiano que proporcione condições de reparação e cura. Porém, não devemos esquecer que o tempo decorrido entre o início da pesquisa de uma nova medicação e seu emprego, vem sendo muito maior do que a diferenciação das bactérias em formas resistentes. 


\subsection{Microbiota das infecções endodônticas persistentes}

Quando há o desenvolvimento ou a persistência de um quadro infeccioso, durante ou após o desenvolvimento de terapia endodôntica adequada, terapias medicamentosas coadjuvantes têm sido pesquisadas no intuito de auxiliar a resolução desses processos.

Heintz, Deblinger e Oliet (1975) estudaram a sensibilidade antibiótica de enterococos que resistiram ao preparo e à medicação do canal radicular. Durante um período de 18 meses, foram feitas culturas positivas obtidas de dentes instrumentados e medicados; e, selecionados pela presença de enterococos. Das culturas examinadas, $44 \%$ continham Streptococcus faecalis ou uma de suas variedades: S. faecalis ss zymogenes ou S. faecalis ss liquefaciens. As cinqüenta cepas testadas foram sensíveis à ampicilina e à vancomicina. Mais de $90 \%$ foram também sensíveis à eritromicina. Todos os microrganismos foram parcialmente ou completamente resistentes à clindamicina, penicilina, estreptomicina e sulfa tripla.

Haapasalo, Ranta e Ranta (1983) relataram dois casos nos quais a terapia endodôntica convencional falhou. Nenhum dos casos respondeu à terapia endodôntica ou ao uso de penicilina, e penicilina com eritromicina. Pesquisas bacteriológicas foram feitas para identificação da microbiota presente. Em um dos casos, foi isolado somente Enterobacter cloacae. No segundo caso, havia presença de enterococos e Klebsiella pneumoniae. Bactérias anaeróbias estritas não foram encontradas. Os autores observaram que a freqüência de bacilos entéricos facultativos Gram-negativos, obtidos a partir de amostras de canais infectados, não excede aos $5 \%$, entretanto consideraram a relação dessas bactérias com infecções 
persistentes. Após tratamento com antibióticos, baseado em testes de suscetibilidade para cada bactéria, o sucesso do tratamento foi alcançado. $\mathrm{Na}$ conclusão do trabalho, os autores destacaram o papel dos microrganismos facultativos Gram-negativos nas infecções periapicais e a necessidade de testes de sensibilidade aos agentes antimicrobianos, para facilitar a escolha do tratamento mais adequado.

Nair et al. (1990) usaram microscopia óptica e eletrônica para analisar 9 dentes assintomáticos portadores de lesão periapical persistente após realização do tratamento endodôntico. Todos os casos foram submetidos à biópsia, na qual foi removido um bloco retangular contendo o terço apical do canal, a lesão periapical e uma fina porção do osso adjacente. Seis, dos nove casos, mostraram a presença de microrganismos no terço apical do canal radicular. Quatro desses continham uma ou mais espécies bacterianas, e em dois casos havia a presença de leveduras. Os achados mostraram que, na maioria dos casos de dentes humanos tratados endodonticamente e portadores de lesões periapicais resistentes à terapia, a presença de microrganismos persistentes atua significativamente no insucesso do tratamento e manutenção da periapicopatia.

O baixo número de espécies bacterianas capazes de sobreviver no interior de canais radiculares sugere que essas possuam mecanismos especiais tanto para a sobrevivência como para a sua multiplicação. A proposta do estudo feito por Sundqvist (1992b) foi identificar associações positivas e negativas entre espécies presentes em canais infectados. Amostras obtidas de 65 canais radiculares humanos infectados foram analisadas quanto às espécies presentes, freqüência e proporção. As espécies mais freqüentes foram Fusobacterium nucleatum, Prevotella intermedia, Peptostreptococcus micros, Peptostreptococcus anaerobius, 
Eubacterium alactolyticum, Eubacterium lentum e Wolinella recta. A associação marcadamente positiva foi encontrada entre $F$. nucleatum e $P$. micros, como também entre Porphyromonas endodontalis, Selenomonas sputigena e W. recta. Houve também associação positiva entre $P$. intermedia e $P$. micros. As espécies de estreptococos e Propionibacterium propionica mostraram associações negativas ou nulas com outras espécies bacterianas. Um bom exemplo de associação é observada entre Peptostreptococcus spp., Eubacterium spp., Bacteroides spp., F. nucleatum, baseada no suprimento nutricional oferecido pelo tecido pulpar infectado. Os resultados desse estudo confirmaram que associações positivas que ocorrem durante a infecção, determinam a presença de uma microflora característica e limitada no interior dos canais radiculares.

Abou-Rass e Bogen (1998) investigaram a flora bacteriana de lesões periapicais persistentes em dentes tratados endodonticamente e clinicamente isoladas de comunicação direta com meio bucal. Treze lesões foram examinadas e amostras bacteriológicas colhidas. Todos os ápices apresentaram culturas positivas, sendo que bactérias anaeróbias estritas estavam presentes em $63,6 \%$ das amostras, enquanto $36,4 \%$ eram constituídas por anaeróbias facultativas. Os microrganismos mais prevalentes foram: Actinomyces spp. (31,8\%), Propionibacterium spp. $(22,7 \%)$, Streptococcus spp. (18,2\%), Staphylococcus spp. (13,6\%) e Gram-negativos entéricos (4,6\%). Com esses dados, os autores puderam concluir que esse tipo de lesão estudada, associada a dentes calcificados ou portadores de quadro clínico refratário, pode abrigar microrganismos. A dificuldade na sua eliminação durante a terapia endodôntica favorece a colonização do ápice e periápice, interferindo no processo de reparação. 
O estudo feito por Molander et al. (1998) investigou a flora microbiana presente em 120 canais já obturados. Os dentes deveriam apresentar canal tratado há mais de quatro anos, sem sintomatologia, e a obturação deveria estar, no máximo, a $5 \mathrm{~mm}$ do ápice radiográfico. Foram então divididos em dois grupos: cem dentes, dentro do grupo denominado patológico $(\mathrm{P})$, e os vinte dentes restantes fizeram parte do grupo denominado técnico $(T)$, por não apresentarem lesão periapical visível radiograficamente. No grupo $\mathrm{P}, 117$ cepas de bactérias foram isoladas em 68 dentes, ou seja, uma ou duas cepas por dente examinado. Das cepas identificadas, $69 \%$ eram bactérias anaeróbias facultativas. O crescimento foi classificado em esparso ou muito esparso em $53 \%$, e pesado ou muito pesado em $42 \%$. Os enterococos foram os mais freqüentes, apresentando um crescimento pesado e muito pesado em 25 dos 32 casos (78\%). Em 11 dentes do grupo T nenhuma bactéria foi encontrada, enquanto nos outros nove foram encontradas 13 diferentes cepas. Os autores concluíram que a flora de canais já obturados difere da encontrada normalmente em canais não-tratados portadores de necrose pulpar, e que a falta de radiolucência apical não significa, necessariamente, ausência de bactérias. O estudo confirmou ainda que bactérias anaeróbias facultativas são menos suscetíveis à atividade antimicrobiana dos tratamentos quando comparadas às estritas, e os enterococos, microrganismos mais freqüentes nos casos de reintervenção.

Em 1998, Sundqvist et al. estudaram a composição da flora microbiana em dentes obturados, com persistência de lesão periapical. Um total de 54 dentes obturados endodonticamente há quatro ou cinco anos, portadores de lesão periapical assintomática, foram selecionados para esse estudo. Após a remoção do material obturador, amostras foram coletadas para cultura e identificação de 
microrganismos. Os dentes foram então preparados, sendo que nenhuma medicação intracanal tenha sido aplicada, para sete dias depois, serem colhidas novas amostras. Em seguida, os canais foram instrumentados com hipoclorito de sódio a $0,5 \%$ e preenchidos com pasta de hidróxido de cálcio (Calasept $(\Omega)$. Nova amostra foi coletada na sessão de obturação, e controle clínico-radiográfico desses casos foi feito anualmente, durante cinco anos. As amostras coletadas dos 54 canais foram positivas para 24 deles. Na segunda consulta, os mesmos microrganismos se mantiveram em vinte canais. Em nove casos, nos quais se constatou a presença de Enterococcus faecalis, não foram isolados outros microrganismos. O índice de sucesso do tratamento atingiu $74 \%$, mas os dentes nos quais foram isolados $E$. faecalis na primeira vez obtiveram o índice de $66 \%$. Na consulta de obturação, seis dentes apresentaram persistência de bactérias nas amostras; quatro deles não obtiveram cura, três acusaram presença de Enterococcus faecalis e Actinomyces israelli. Os achados mostraram que o tamanho inicial da lesão parece influenciar os resultados, uma vez que lesões maiores obtiveram o menor índice de cura. Enterococcus faecalis, Candida albicans e Actinomyces israelli mostraram resistência à terapia antimicrobiana e foram capazes de sobreviver em ambientes com nutrição restrita. Os autores afirmaram ainda que, sempre que possível, a reintervenção deve ser a terapia de escolha, na medida em que aumenta a porcentagem do sucesso endodôntico.

A pesquisa de Dahlén et al. (2000) identificou espécies de enterococos em 29 casos de infecção endodôntica, após o preparo do canal e aplicação de medicação a base de hidróxido de cálcio. Foi feito estudo in vitro da sensibilidade antimicrobiana das cepas isoladas diante da benzilpenicilina, ampicilina, clindamicina, metronidazol, tetraciclina, eritromicina e vancomicina. Os enterococos foram isolados em todas as 
amostras, sendo $79,3 \%$ em forma de monoinfecção. Enterococcus faecalis foi isolado em 26 amostras, enquanto Enterococcus faecium, em apenas três. Os resultados mostraram que todas as espécies foram sensíveis à vancomicina e à eritromicina, porém resistentes aos outros agentes testados. Os autores concluíram que, devido à baixa sensibilidade aos agentes antimicrobianos, os enterococos podem ser selecionados após terapia endodôntica convencional, contribuindo significativamente para o insucesso do tratamento de canais infectados.

Investigar a ocorrência de Enterococcus faecalis em tratamentos endodônticos mal sucedidos foi o alvo do estudo feito por Peciuliene et al. (2000). Foram selecionados 25 canais parcialmente obturados, com presença de rarefação óssea apical em dentes assintomáticos. Durante a sessão de desobturação, nenhum solvente foi utilizado para evitar a perda da viabilidade dos microrganismos. Amostras foram coletadas antes e depois do preparo dos canais, para os quais o hipoclorito de sódio a $2,5 \%$ e o EDTA foram as soluções irrigadoras de escolha. Foram isoladas bactérias em vinte canais estudados. E. faecalis foi o microrganismo mais freqüente, tendo sido isolado em 14 amostras (70\%), e quando não estava em cultura pura (cinco amostras) estava associado a outras bactérias (nove amostras). Após o preparo do canal, sete dentes apresentaram culturas positivas, sendo que o E. faecalis estava presente em cinco delas. Os resultados indicaram que, independentemente dos tratamentos com soluções bactericidas, as condições oferecidas por canais radiculares parcialmente obturados favorecem a presença de E. faecalis, contribuindo para o insucesso da terapia endodôntica.

Pinheiro et al. (2000) estudaram a microbiota de 28 dentes com tratamento endodôntico prévio e lesões periapicais visíveis radiograficamente. Após a remoção do material obturador, sem o uso de qualquer solução que pudesse interferir na 
viabilidade bacteriana, foi realizada a coleta microbiológica com cones de papel absorvente, depois da irrigação dos canais com água destilada. Tanto a coleta, como o transporte, cultura e incubação respeitaram as condições exigidas para crescimento de bactérias anaeróbias estritas. Microrganismos viáveis estavam presentes em $75 \%$ dos casos, sendo que a maioria dos canais apresentou somente uma ou duas espécies bacterianas (77,7\%). Foram isoladas 38 diferentes espécies: $57,9 \%$ anaeróbias facultativas, $47,1 \%$ anaeróbias estritas, $81,5 \%$ Gram-positivas e 18,5\% Gram-negativas. Os gêneros mais isolados foram: Streptococcus $(32,1 \%)$, Enterococcus (17,9\%), Peptostreptococcus (10,7\%), Actinomyces (10,7\%) e Prevotella $(7,1 \%)$. Os autores concluíram que a microbiota dos canais tratados endodonticamente sem sucesso, é formada em sua maioria por uma ou duas espécies, representadas principalmente por bactérias anaeróbias facultativas Grampositivas.

O desenvolvimento de técnicas sofisticadas na cultura de bactérias anaeróbias possibilitou que alguns pesquisadores iniciassem uma nova abordagem na investigação da microbiota do canal radicular, em tratamentos endodônticos mal sucedidos. O alvo do estudo de Hancock III et al. (2001) foi pesquisar a composição da microbiota em 54 casos de insucesso, comparando os resultados aos obtidos em trabalhos escandinavos similares. O material das amostras foi coletado com cones de papel absorvente ou por meio de instrumentos manuais cortantes, tais como alargadores. O exame microbiológico mostrou que, na maioria dos casos, de uma a três espécies bacterianas estavam presentes no interior dos canais, sendo o Enterococcus faecalis o microrganismo mais freqüente (30\%). Os autores observaram ainda que nos casos de polpa necrótica a presença desse microrganismo é significativamente menor. $O$ aumento da presença de $E$. faecalis 
nos casos de reintervenção pode ocorrer devido à assepsia inadequada, isolamento absoluto falho, infiltração coronária durante o tratamento inicial e, principalmente, aplicação de medicação a base de hidróxido de cálcio, que atua como meio seletivo. Os autores concluíram que os resultados obtidos foram compatíveis com estudos prévios e destacaram a importância da seleção de soluções irrigadoras e do tipo de medicação intracanal para serem empregadas nas reintervenções endodônticas.

Dados obtidos a partir de experimentos com Enterococcus faecalis mostram que esse microrganismo desempenha importante papel no desenvolvimento de patologias crônicas, relacionadas aos tratamentos endodônticos mal sucedidos (HANCOCK III et al., 2001). Sua capacidade de sobreviver em forma de monoinfecção e sua resistência à medicação intracanal estimularam Love (2001) a desenvolver um estudo que explicasse um possível mecanismo que pudesse tornar viável sua sobrevivência no interior dos túbulos dentinários, provocando a reinfecção do canal radicular obturado. Foi estudado o comportamento de três diferentes espécies bacterianas (Streptococcus gordonii, Streptococcus mutantes e Enterococcus faecalis) quanto a invasão de túbulos dentinários e fixação no colágeno, na presença de soro humano. O estudo demonstrou que $E$. faecalis permanece viável após a invasão dos túbulos dentinários e aderência ao colágeno, principalmente na presença de soro humano (que contém proteínas). A avaliação das outras espécies mostrou uma significativa diminuição da sua fixação no colágeno na presença do soro, sugerindo que esse processo seja em parte responsável pela inibição da migração desses microrganismos para os túbulos dentinários. Os autores concluíram que a habilidade do E. faecalis em causar lesões periapicais crônicas envolvidas com insucessos da terapia endodôntica está 
relacionada com a sua capacidade de invadir os túbulos dentinários e permanecer viável em seu interior.

Kalfas, Figdor e Sundqvist (2001) descreveram dois casos clínicos de infecção persistente após terapia endodôntica convencional. O objetivo do estudo foi determinar quais microrganismos estariam presentes no interior desses canais e suas principais características. Após a remoção de todo o material obturador, foram colhidas amostras por meio de técnicas microbiológicas avançadas, bem como foi efetuada a caracterização das espécies isoladas. Em ambos os casos, foi isolada uma nova espécie de Actinomyces spp. Essa espécie, denominada Actinomyces radicidentis, foi identificada e caracterizada com base em suas características filogênicas e fenotípicas. Os resultados indicaram que essa nova espécie está associada aos casos de infecções endodônticas resistentes aos tratamentos convencionais.

O aprimoramento de técnicas laboratoriais de cultivo de bactérias anaeróbias, vêm permitindo maior entendimento dos mecanismos de sobrevivência desses microrganismos nas patologias pulpares e periapicais. Um estudo feito por Lana et al. (2001) analisou microbiologicamente 31 canais infectados antes e depois da manobra de instrumentação. Em 24 canais foram encontradas bactérias anaeróbias estritas $(88,9 \%)$, cinco diferentes espécies microbianas em média por canal. Os gêneros mais encontrados foram Prevotella, Fusobacterium, Lactobacillus, Streptococcus, Clostridium, Peptostreptococcus, Candida e Saccharomyces. Outro achado importante foi a permanência de anaeróbios facultativos em dois casos, e leveduras em três canais estudados, mesmo após a instrumentação e uso do hidróxido de cálcio como medicação intracanal. Ao final do tratamento, microrganismos foram isolados de sete canais, 5 desses infectados por anaeróbios 
facultativos e um por levedura. Quanto à suscetibilidade aos antimicrobianos, os autores observaram a ineficácia da eritromicina frente aos gêneros Veillonella, Peptostreptococcus e Fusobacterium, confirmando assim, sua baixa atividade na inibição do crescimento desse grupo de microrganismos freqüentes nas infecções endodônticas. A resistência de anaeróbios facultativos também ao metronidazol alerta para a escolha de uma terapia antimicrobiana específica, com o objetivo de minimizar ao máximo o aumento dessa resistência entre os microrganismos.

A avaliação do efeito antimicrobiano do gluconato de clorexidina e de medicações contendo antibióticos, em biofilmes formados por Enterococcus faecalis, foi a proposta do estudo publicado por Lima et al. (2001). Um inóculo da cepa $E$. faecalis ATCC 29212, ajustado em 0,08 a 0,10 (comprimento de onda de $625 \mathrm{~nm}$ ), foi colocado em contato com membranas de nitrato de celulose para estimular a formação de biofilme, por um período de 1 e 3 dias a $37^{\circ} \mathrm{C}$. Seis grupos formados por diferentes medicações em forma de gel, descritos a seguir, foram estudados:

1- gluconato de clorexidina $2 \%$, natrozol a $2 \%$, em água destilada;

2- gluconato de clorexidina $2 \%$, sulfato de lauril-dietileno-glicol-éter-sódio a $1,25 \%$, natrozol a $2 \%$, em água destilada;

3- clindamicina $2 \%$, natrozol $2 \%$, em água destilada;

4- clindamicina a $2 \%$, sulfato de lauril-dietileno-glicol-éter-sódio a 1,25\%, natrozol $2 \%$, em água destilada;

5- gluconato de clorexidina a $2 \%$, óxido de zinco a $15 \%$, sulfato de laurildietileno-glicol-éter-sódio a 1,25\%, natrozol a 2\%, em água destilada;

6- clindamicina a $2 \%$, metronidazol a $10 \%$, sulfato de lauril-dietileno-glicoléter-sódio a 1,25\%, natrozol a $2 \%$, em água destilada. 
Todas as associações mostraram redução da população bacteriana nos dois biofilmes (1 e 3 dias). A associação da clindamicina com o metronidazol reduziu significativamente o número de células do biofilme de um dia. Entretanto, de todas as medicações testadas, as que apresentaram melhor desempenho foram aquelas que continham gluconato de clorexidina $2 \%$, eliminando $E$. faecalis tanto do biofilme de 1 dia como no de 3 dias de desenvolvimento.

Sunde et al. (2002) demonstraram a ampla variedade de microrganismos, particularmente Gram-positivos, presentes na microbiota de lesões refratárias. Foi investigada a microbiota de 36 dentes portadores de lesão periapical, que não responderam ao tratamento convencional e ao uso de medicação com hidróxido de cálcio, por períodos maiores do que seis meses. Oito pacientes ainda foram submetidos à antibioticoterapia, complementando a abordagem antimicrobiana proposta durante o tratamento endodôntico. Um total de 148 diferentes cepas foram identificadas a partir de um grupo de 67 espécies, presentes nas amostras e processadas em ambiente de anaerobiose. Aproximadamente, metade das amostras apresentou bactérias anaeróbias (51\%) e $75 \%$ eram Gram-positivas. Entre as facultativas, isoladas em $75 \%$ dos casos, foi encontrado Staphylococcus, Enterococcus, Enterobactéria, Stenotrophomonas, Shingomonas, Bacillus e Candida. Somado a esse resultado, a presença de grânulos sulfúricos em $25 \%$ dos casos, observada por microscopia eletrônica (MEV e MET), sugere sua relação com a persistência da periodontite apical resistente à terapia endodôntica convencional.

Pinheiro et al. (2003b) avaliaram a microbiota de 30 canais obturados com lesão periapical persistente, partindo da premissa que existem diferenças marcantes quando comparada à microbiota de dentes com polpa necrosada. Utilizando técnicas específicas para o resgate de espécies anaeróbias, foram isoladas 55 espécies 
bacterianas, sendo $80 \%$ de Gram-positivas e $58 \%$ de microrganismos anaeróbios facultativos. Os gêneros mais isolados foram: Enterococcus, Streptococcus e Peptostreptococcus. Todas as espécies foram suscetíveis a benzilpenicilina, amoxacilina e amoxacilina combinada com o clavulanato. Entretanto, $20 \%$ das cepas de E. faecalis foram resistentes a eritromicina e $60 \%$ a azitromicina. Os autores destacaram ainda, no caso de pacientes alérgicos às penicilinas, que a antibioticoterapia fica bastante restrita no caso de infecções por Enterococcus faecalis.

Com o objetivo de identificar microrganismos presentes no interior de canais radiculares tratados e portadores de lesão periapical persistente, Pinheiro et al. (2003a) coletaram amostras de 60 dentes com essas características, utilizando técnicas microbiológicas para resgate de espécies anaeróbias. Foram isolados microrganismos em 51 dos 60 canais avaliados, sendo encontradas uma ou duas espécies por canal. Do total de bactérias isoladas, 57,4\% eram anaeróbias facultativas e $83,3 \%$ Gram-positivas. Enterococcus faecalis foi a espécie mais freqüente nos canais que apresentaram crescimento de microrganismos $(52,94 \%)$, e em 18 deles estava presente na forma de monoinfecção ou cultura pura. Entretanto, infecções de caráter polimicrobiano, compostas por anaeróbios estritos (Peptostreptococcus spp, Prevotella spp. e Fusobacterium spp.), foram freqüentemente encontradas nos casos sintomáticos, sendo Peptostreptococcus o gênero mais isolado.

Com a proposta de detectar enterococos, enterobactérias e leveduras, todos microrganismos superinfectantes, a partir de infecção endodôntica primária, Ferrari, Cai e Bombana (2005) investigaram 25 dentes unirradiculares com necrose pulpar e câmara coronária intacta. Amostras coletadas em diversas fases da terapia 
endodôntica foram analisadas microbiologicamente. Na coleta inicial (obtida antes de qualquer intervenção), microrganismos foram detectados em $92 \%$ dos canais, sendo $22 \%$ constituídos por superinfectantes, os quais não foram mais isolados após o preparo químico-cirúrgico. Após 7 dias, sem qualquer medicação intracanal, 100\% dos canais estavam colonizados por microrganismos, sendo $52 \%$ desses representados pelos oportunistas pesquisados. No entanto, após o emprego da medicação intracanal PRP (paramonoclorofenol, polietilenoglicol 400 e Rinossoro) durante 7 dias, bacilos entéricos e leveduras não foram mais detectados, com exceção dos enterococos, especialmente $E$. faecalis e $E$. faecium, que sobreviveram aos procedimentos endodônticos em 3 casos.

O objetivo da pesquisa de Vivacqua-Gomes et al. (2005) foi avaliar in vitro a presença de Enterococcus faecalis após a realização da terapia endodôntica em uma ou mais sessões. Quarenta e cinco dentes foram infectados experimentalmente por um período de 60 dias com inóculo de E. faecalis e divididos em cinco grupos de acordo com o tempo decorrido entre a instrumentação e a obturação do canal, substância química utilizada e uso de medicação intracanal a base de hidróxido de cálcio. O grupo 1 foi instrumentado na presença de $0,5 \mathrm{~mL}$ de clorexidina gel e imediatamente obturado. O grupo 2 seguiu um protocolo semelhante, porém, recebendo medicação intracanal a base de hidróxido de cálcio por 14 dias. No grupo 3, após a instrumentação na presença de clorexidina gel, os canais foram preenchidos com meio de cultura BHI (Brain Heart Infusion) por 7 dias. Os espécimes dos grupos 4 e 5 representaram os controles positivos do experimento, sendo instrumentados apenas com solução salina estéril e preenchidos respectivamente por meio de cultura $\mathrm{BHI}$ por 7 dias e cones de guta-percha sem adição de cimento endodôntico. Os espécimes dos grupos 2, 3 e 4 foram então 
obturados com cones de guta-percha e cimento tipo Grossman, mantidos por 60 dias a $37{ }^{\circ} \mathrm{C}$, juntamente com os outros dois grupos (1 e 5). Decorrido esse período de incubação, raspas de dentina foram obtidas dos espécimes e processadas para cultivo, com o objetivo de detectar células bacterianas viáveis. Os resultados mostraram que as bactérias estudadas estavam presentes em $20 \%$ dos espécimes do grupo 1 e em $25 \%$ no grupo 2. Os grupos 3, 4 e 5 apresentaram respectivamente 40, 60 e 100\% de E. faecalis viáveis, valores significativamente maiores aos encontrados nos grupos 1 e 2. Os autores puderam concluir que o $E$. faecalis não foi completamente eliminado em nenhuma das situações experimentais e que, mesmo após 60 dias da obturação endodôntica, permaneciam viáveis principalmente no grupo no qual não foi utilizado o cimento endodôntico na obturação.

O estudo in vivo realizado por Zerella, Fouad e Spắngberg (2005), comparou o efeito da associação de pasta de hidróxido de cálcio com clorexidina e pasta de hidróxido de cálcio em água, usadas como medicação intracanal em casos de reintervenção endodôntica, nos quais tratamentos prévios falharam. Quarenta dentes unirradiculares com lesões detectadas radiograficamente, foram selecionados para a investigação. Os canais foram instrumentados na presença do hipoclorito de sódio a $1 \%$ e preenchidos com pasta de hidróxido de cálcio em solução de clorexidina a $2 \%(n=20)$, ou hidróxido de cálcio em água deionizada $(n=20)$. Pelo menos três trocas sucessivas foram feitas, com intervalos que variaram entre 7 e 10 dias. Para avaliação microbiológica, amostras foram obtidas dos canais antes das manobras de desinfecção, no início e no final de cada consulta. Em todos os canais havia a presença de microrganismos na amostra inicial. Enterococos estava presente em todos os casos e por meio de técnicas moleculares foi possível identificar Enterococcus faecalis em 4 canais de cada um dos grupos. Apenas 12 
dos 40 canais $(30 \%)$ apresentaram culturas positivas no momento da obturação endodôntica, sendo somente 4 pertencente ao grupo do hidróxido de cálcio associado a clorexidina. Não foi obtida nenhuma cultura positiva dos canais inicialmente infectados por E. faecalis. Esse estudo mostrou que a associação do hidróxido de cálcio com solução de clorexidina melhorou as propriedades antimicrobianas do hidróxido de cálcio, principalmente frente ao E. faecalis, bactéria frequentemente isolada em canais tratados portadores de periapicopatias crônicas.

A questão da resistência apresentada por Enterococcus faecalis em ambientes ácidos ou alcalinos, foi investigada por Nakajo et al. (2006). Nesse estudo foram pesquisados mecanismos bioquímicos que conferem essa propriedade ao $E$. faecalis quando comparado ao Streptococcus mutans.

Os resultados mostraram que o crescimento do $E$. faecalis ocorreu em $\mathrm{pH}$ entre 4,0 e 11 , enquanto o $S$. mutans cresceu em $\mathrm{pH}$ entre 4,0 e 9,0. As duas espécies mostraram-se resistentes em ambas situações, sendo que o $E$. faecalis manteve seu pH interno entre 7,5 e 10. Além disso, sua membrana externa mostrouse resistente ao meio ácido, mantendo seu pH próprio para o crescimento, mesmo frente a valores de $\mathrm{pH}$ abaixo de 5 . A maior resistência em meio extremamente alcalino, como aquele oferecido pela presença de hidróxido de cálcio, foi apresentada pelo E. faecalis, devido à capacidade de sua membrana em manter o $\mathrm{pH}$ interno relativamente neutro.

Um estudo feito por Radcliffe et al. (2004) confirma a resistência de alguns microrganismos às manobras utilizadas rotineiramente no combate à infecção do sistema de canais radiculares, principalmente no que se refere a presença de Enterococcus faecalis. A proposta dessa investigação foi determinar a resistência de microrganismos associados à presença de infecções endodônticas refratárias, frente 
ao hipoclorito de sódio em diferentes concentrações. Para isso foram utilizadas cepas de Actinomyces israelli, Actinomyces naeslundii, Candida albicans e E. faecalis, bem como o hipoclorito de sódio nas concentrações de 0,5\%,1\%,2,5\% e $5,25 \%$. Todas as cepas foram expostas diretamente às diferentes concentrações de hipoclorito de sódio, por períodos que variaram de 0 a 120 segundos. No caso do $E$. faecalis, esse tempo se estendeu até 30 minutos de exposição.

Todas as concentrações da solução estudada foram eficazes na eliminação de Actinomyces e Candida, em um período de 10 segundos. Por outro lado, o E. faecalis não foi detectado nas culturas feitas após o contato com hipoclorito de sódio a $0,5 \%$ por períodos acima de 30 minutos exposição, provando ser o microrganismo mais resistente do experimento. As concentrações de hipoclorito de sódio a 1, 2,5 e $5,25 \%$ eliminaram o $E$. faecalis em 10, 5 e 2 minutos, respectivamente.

Poucos trabalhos na literatura têm investigado as propriedades antimicrobianas da clorexidina no interior dos canais in vivo. Isso motivou Siqueira Jr, Paiva e Roças (2007) a avaliarem 13 dentes portadores de infecção endodôntica primária e periodontite apical crônica.

O digluconato de clorexidina $0,12 \%$ foi usado como substância irrigadora, enquanto que a associação de clorexidina gel a $0,12 \%$ com hidróxido de cálcio, exerceu efeito antimicrobiano complementar entre sessões. Três amostras foram colhidas do interior dos canais selecionados para pesquisa, em três momentos: antes do preparo do canal (S1), após o preparo químico-cirúrgico (S2) e sete dias após o preenchimento dos canais com pasta de hidróxido de cálcio veiculado em digluconato de clorexidina a $0,12 \%$. 
Para o isolamento e identificação dos microrganismos presentes nas amostras foi utilizada a técnica de seqüenciamento de RNA ribossômico (16SrRNA), através da extração de DNA das colônias.

Em S1, todas as amostras mostraram crescimento microbiano, sendo a média de crescimento igual a $1,1 \times 10^{6} \mathrm{ufc} / \mathrm{mL}$, variando de $2,8 \times 10^{3}$ à $1,0 \times 10^{8} \mathrm{ufc} / \mathrm{mL}$. S2, por sua vez, apresentou bactérias viáveis em sete casos, correspondentes a $53,8 \%$ dos canais. Somente em um caso $(7,7 \%)$ o crescimento de microrganismos foi detectado após o uso da medicação intracanal com a associação proposta. Nesse grupo (S3) houve uma notória diminuição da infecção e um aumento proporcional no número de culturas negativas (12 das 13 amostras). $O$ único caso positivo apresentou $1,56 \times 10^{3}$ ufc/mL, correspondente a $99,7 \%$ de redução no número de microrganismos presentes inicialmente.

Concluiu-se que apesar da clorexidina a $0,12 \%$ apresentar ação antimicrobiana frente a infecções endodônticas primárias, ela permitiu o crescimento de microrganismos em metade dos dentes avaliados, enquanto que a aplicação de uma medicação intracanal composta por clorexidina gel e hidróxido de cálcio foi efetiva, eliminando quase que completamente a infecção.

\subsection{Terapia bacteriofágica}

A terapia bacteriofágica vem sendo estudada desde o início do século $X X$ e utiliza fagos, vírus que infectam bactérias, no controle de infecções. O sucesso do 
uso dos antibióticos desestimulou o desenvolvimento da fagoterapia durante muitos anos.

Hoje, com o aumento da resistência bacteriana a agentes quimioterápicos, nova fase da pesquisa com fagos foi iniciada.

Fagos para Lactobacillus, bactérias conhecidas por seu envolvimento no processo da cárie dental, foram investigados por Meyers, Walter e Green (1958).

Os autores utilizaram 12 diferentes espécies de lactobacilos, dentre elas o $L$. casei, L. acidophilos, L. fermenti, L. salivarius, L. helviticus e lactobacilos não fermentadores de lactose.

A cavidade oral dos próprios pesquisadores serviu como fonte de coleta das amostras, com o objetivo do isolamento dos fagos específicos para as bactérias citadas. A avaliação foi feita valendo-se da observação de placas de lise formadas em meio sólido contendo as cepas alvo, preparadas para cada uma das 12 espécies. Foi constatada atividade lítica em placas contendo 6 espécies de lactobacilos. Essa atividade foi mais significante em relação a cepas de L. casei e lactobacilos não fermentadores de lactose.

Os autores sugerem, ao final do estudo, que existe uma possível relação entre a presença de bacteriófagos na cavidade oral e infecções orofaríngeas, mas que a participação dos fagos nessa microbiota ainda não está bem esclarecida.

Com a proposta de estudar molecular e geneticamente a patogenicidade de estreptococos, Greer et al. (1971), isolaram fagos a partir Streptococcus mutans e Streptococcus salivarius.

Para a obtenção dos fagos, amostras isoladas da cavidade oral de indivíduos com presença ou não de cáries, foram submetidas à irradiação ultravioleta (UV) por 30 a 100 segundos (2600 A) ou expostas a mitomicina (concentração de 3,5 $\mu \mathrm{g} / \mathrm{mL}$ ), 
por um período de 1 hora. Esses dois métodos são utilizados para induzir fagos, em estado lisogênico no interior da bactéria, a iniciar seu ciclo lítico, sendo então liberados. Os resultados mostraram que todas as cepas cariogênicas de estreptococos sofreram lise após as induções tanto dos raios UV quanto após a exposição a mitomicina. Os fagos liberados foram estudados por MET e mostraram similaridade em sua morfologia e no seu conteúdo nuclear (DNA).

Os autores concluíram que os resultados do estudo apontam para uma participação desses fagos no processo cariogênico, ou mesmo no controle epidemiológico dessas cepas quando estabelecidas na cavidade oral de seres humanos.

Considerando a complexidade da microflora presente, temperatura em torno de $37{ }^{\circ} \mathrm{C}$ e consistência semi-sólida da placa bacteriana formada na superfície dos dentes, a cavidade oral oferece um dos melhores habitats naturais para propagação dos fagos.

Durante o estudo da ultra-estrutura da placa bacteriana através de microscopia eletrônica, Halhoul e Colvin (1975) observaram imagens com densidades e morfologias semelhantes a vírus, o que sugeriu a presença de fagos na placa dental. O estudo das imagens mostrou que essas partículas virais apresentavam morfologia uniforme, hexagonal de diâmetro em torno de $50 \mathrm{~nm}$, consistente com o tamanho de bacteriófagos. Algumas imagens mostraram bacilos com citoplasma preenchido por fagos e outros lisados, sugerindo que essas bactérias estavam sofrendo ruptura característica do processo de infecção por fagos líticos.

Apesar desse estudo não identificar o tipo de bactérias alvo da infecção específica por fagos, ele mostra a associação desses no controle natural do 
crescimento bacteriano, influenciando o metabolismo e sobrevivência de certas espécies presentes na placa dental.

A proposta do estudo feito por Hiroki et al. (1976) foi isolar tipos de bacteriófagos para cepa de Veillonella spp., bactéria anaeróbia Gram-negativa presente na microbiota normal da boca e placa dental.

Foram usadas cepas de V. alcalescens, V. parvula e V. reniformis, para propagação e isolamento de fagos a partir da cavidade oral, de pacientes da clínica do Nippon Dental College. Os pacientes usaram água destilada como colutório e uma alíquota de $10 \mathrm{~mL}$ dessa solução foi enriquecida, separadamente, com $2 \mathrm{~mL}$ de suspensão de cada uma das cepas de Veillonella spp. Após o processamento por centrifugação e titulação de 200 diferentes amostras coletadas, foram isolados 25 tipos de bacteriófagos, divididos em dois grupos conforme a morfologia das unidades formadoras de placa e características sorológicas. Os autores notaram ainda que ocorreu similaridade entre os fagos isolados de diferentes pacientes, fato não explicado até então.

Brady, Gray e Caldwell (1977) investigando a ultra-estrutura da placa bacteriana empregando microscopia eletrônica de transmissão (MET), observaram a presença de estruturas semelhantes às partículas virais. Foram feitas coletas de placa bacteriana de diferentes áreas do sulco gengival de um mesmo indivíduo e processamento desse material para exame em MET. As micrografias revelaram uma mistura de microrganismos e células epiteliais comumente encontradas nesse material, incluindo cocos, pequenos bacilos, organismos fusiformes e bactérias filamentosas. Um exame mais detalhado mostrou citoplasma dos organismos fusiformes preenchido por partículas radiolúcidas de formato hexagonal, apontando para uma infecção desses microrganismos por bacteriófagos. Cápsulas virais 
portadoras de filamento, desprovidas de seu conteúdo nuclear, indicando a ocorrência de infecção de células bacterianas, também foram observadas. Outras micrografias mostraram pequenas partículas virais no interior de bacilos ou cocobacilos Gram-positivos.

Os autores concluíram que seus achados provam que microrganismos presentes na placa bacteriana são suscetíveis à infecção por bacteriófagos específicos, apesar desses últimos não estarem presentes de forma livre no interior desse material.

O objetivo inicial da pesquisa de Smith e Huggins (1982), na Grã-Bretanha, foi o de estudar a relação entre fago e microrganismo que pudesse explicar o baixo índice de sucesso no combate às infecções in vivo. Eles afirmaram, nesse trabalho, que a principal razão do insucesso da terapia bacteriofágica na cura de infecções tem sido a diminuição da sua atividade in vivo quando comparada à sua atividade in vitro, e rápido aparecimento de microrganismos mutantes resistentes ao fago. A obtenção de resultados surpreendentemente satisfatórios fez com que a pesquisa se estendesse, comparando ainda fagoterapia com a antibioticoterapia. Foram usados, no estudo, ratos brancos inoculados com doses potencialmente letais de Escherichia coli (MW), via intramuscular e intracerebral. Os espécimes também receberam doses de diferentes fagos, em diferentes tempos. $O$ fago $R$, pertencente a um grupo denominado anti-K1, mostrou ser mais efetivo do que outros fagos estudados. Uma única dose intramuscular de fago $R$ foi mais eficaz do que múltiplas doses de tetraciclina, ampicilina, cloranfenicol e trimetoprima acrescido de sulfafurazole. A notada superioridade do fago $\mathrm{R}$ em relação a uma única dose de estreptomicina destacou sua capacidade em se autoperpetuar na presença de bactérias suscetíveis, característica das mais desejáveis no que diz respeito a agentes 
antimicrobianos. Quando o fago foi administrado três a cinco dias antes da inoculação da cepa, foi observada ainda uma ação profilática, que variou conforme a capacidade de propagação do fago. Os achados indicaram que não houve diminuição da atividade do fago $\mathrm{R}$ in vivo, e nem mesmo o rápido aparecimento de bactérias resistentes, sugerindo assim que esse fago age rapidamente na eliminação das bactérias suscetíveis. As bactérias resistentes que surgiram durante 0 tratamento apresentaram baixa virulência.

Smith e Huggins (1983) pesquisaram o uso da terapia bacteriofágica em bezerros, leitões e cordeiros, infectados por via oral, com três diferentes cepas enteropatogênicas de Escherichia coli. Bezerros foram inoculados com dose letal de E. coli denominada B44. Uma mistura de fagos B44/1 e B44/2 foi administrada, protegendo os bezerros contaminados. Nesse caso, a cura ocorreu antes que sinais e sintomas aparecessem. Quando o fago B44/2 foi substituído pelo fago B44/3 na mistura, ocorreu processo de cura mesmo após o início da doença. Bezerros inoculados oralmente com fezes contaminadas de animais tratados com fagos, que desenvolveriam infecção letal, mantiveram-se saudáveis. Outra mistura de fagos foi administrada em leitões, contaminados por via oral com cepa de E. coli denominada P433. Foi estudada tanto a administração da mistura de fagos P433/1 com P433/2, como também a ação do fago $\mathrm{P} 433 / 1$ isolado. Em ambos os casos houve a cura do processo infeccioso. A terceira parte da pesquisa foi feita com cordeiros contaminados da mesma forma, com cepa de E. coli denominada S13. Mesmo após um período de 8 horas da inoculação da cepa, os fagos administrados reduziram significativamente o número de bactérias presentes no trato digestivo e, conseqüentemente, houve uma melhora no quadro clínico desses animais. As 
únicas bactérias resistentes que surgiram nos bezerros e leitões mostraram-se muito menos virulentas em comparação com as cepas iniciais.

Slopek et al. (1984) analisaram os resultados de 150 casos de infecção bacteriana supurativa em seres humanos, tratadas com terapia bacteriofágica. A terapia obteve sucesso em 137 dos casos estudados (91,3\%). Esses resultados confirmaram a efetividade do bacteriófago nesse tipo de infecção séptica, espontânea e pós-operatória, causada por Staphylococcus spp., Klebsiella spp., Escherichia spp., Proteus spp. e Pseudomonas spp.

Tylenda et al. (1985) estudaram a presença de bacteriófagos para Actinomyces viscosus e Streptococcus sanguis, isolados a partir de amostras de placa bacteriana obtidas do sulco gengival de pacientes em tratamento odontológico de rotina.

Uma mistura de placa bacteriana sub e supra gengival foi coletada das superfícies dentais de indivíduos, sem levar em consideração características como sexo, idade, saúde geral ou presença de patologias orais como cárie e doença periodontal. Das 336 amostras estudadas, nenhuma acusou a presença de fagos para S. sanguis, enquanto dez dessas mesmas amostras continham fagos líticos para $A$. viscosus. Como o estudo foi randomizado, não foi possível associar tal presença à saúde geral e bucal dos pacientes.

Nesse mesmo trabalho, os pesquisadores identificaram pela primeira vez na literatura, uma cepa de Actinomyces naeslundii passível de infecção por fagos.

Este estudo mostrou que talvez os fagos para Actinomyces spp. façam parte da microbiota normal da cavidade oral, sendo a placa bacteriana uma boa fonte para sua detecção e isolamento. 
Smith, Huggins e Shaw (1987b) decidiram investigar possíveis fatores extrínsecos que pudessem interferir na eficácia da fagoterapia, com o propósito não só de identificá-los, mas também de modificá-los, aumentando as possibilidades de cura dos processos infecciosos. Dentre esses fatores estão a presença de anticorpos no sangue do hospedeiro, temperatura corporal e exposição a desinfetantes. O estudo foi feito in vitro, com cepas de Escherichia coli enteropatogênicas tanto para bezerros, leitões e carneiros, como para seres humanos. Os resultados mostraram que parece improvável que baixas concentrações de anticorpos pudessem destruir os fagos, mas que freqüentes exposições levariam ao crescimento do número desses anticorpos, complicando o uso da terapia bacteriofágica. Essa situação poderia ser contornada com o uso de fagos antigenicamente diferentes. A virulência de 21 tipos de fagos variou de acordo com as diversas temperaturas estudadas. A maioria foi quase avirulenta nas temperaturas de $20{ }^{\circ} \mathrm{C}$ e $43{ }^{\circ} \mathrm{C}$, enquanto a $37{ }^{\circ} \mathrm{C}$, mais virulenta. Quanto aos desinfetantes, os fagos foram neutralizados na presença de formaldeído e hipoclorito de sódio. Os autores concluíram que a grande variedade no padrão comportamental dos diferentes fagos estudados sugeriu que muitos fatores estão envolvidos na determinação de sua atividade.

Smith, Huggins e Shaw (1987a) investigaram a ação de sete fagos na cura de infecção severa por Escherichia coli experimentalmente induzida em bezerros. Os fagos isolados a partir de água de esgoto mostraram-se altamente capacitados na eliminação de diferentes cepas de E. coli, tanto in vivo como in vitro. Uma única dose de fagos $\left(10^{5}\right.$ organismos viáveis) foi suficiente para a cura da diarréia nos bezerros infectados. A prevenção da doença foi também atingida quando uma suspensão aquosa de fagos (apenas $10^{2}$ organismos viáveis) foi esborrifada nos cercados 
ocupados anteriormente por animais doentes. Exames microbiológicos revelaram que os fagos se multiplicaram rapidamente e difusamente no intestino dos bezerros inoculados, reduzindo o número de bactérias, tornando a doença inofensiva. As únicas bactérias mutantes resistentes ao tratamento, denominadas $\mathrm{K}^{-}$, apresentaram baixa virulência em relação às bactérias das quais se originaram $\left(\mathrm{K}^{+}\right)$, não sendo consideradas fator de risco à saúde dos animais.

Cislo et al. (1987) estudaram 31 casos de pacientes portadores de infecção crônica supurativa de pele, causada por Pseudomonas spp., Staphylococcus spp., Klebsiella spp., Proteus spp. e Escherichia spp. Entre duas e 16 semanas de tratamento, houve uma melhora do estado geral dos pacientes bem como a diminuição da inflamação no local, depuração da ferida, rápida reparação das úlceras e resultados negativos aos testes bacteriológicos. Em 16 casos foi obtido excelente efeito terapêutico, em outros sete casos houve uma melhora significante e em dois casos houve uma melhora transitória. O tratamento foi abandonado em sete pacientes que apresentaram efeitos colaterais e em um único caso por falta de efetividade.

A eficiência da terapia bacteriofágica específica foi estudada por Bogovazova, Voroshilova e Bondarenko (1991) nos casos de infecção experimental por Klebsiella pneumoniae, em ratos brancos não-consangüíneos. A infecção foi causada por uma injeção intraperitoneal de cepa da bactéria citada, de alta virulência. O tratamento foi feito pela administração de bacteriófago polivalente para Klebsiella spp. dois dias após os animais terem sido inoculados. O estudo mostrou que o bacteriófago podia ser detectado no sangue e nos órgãos internos dos animais nas primeiras 24 horas. O preparado de bacteriófagos administrado pela via intraperitoneal mostrou ser eficiente no tratamento da infecção generalizada por Klebsiella spp. Uma aplicação 
diária, durante 15 a vinte dias, foi suficiente na eliminação das bactérias. Ao contrário das quimioterapias, o uso dos bacteriófagos não alterou a microflora normal. Por essas razões, os autores concluíram que o uso do fago como medicação alternativa antimicrobiana deve ser considerado.

Kwarcinski et al. (1994) estudaram o emprego da terapia bacteriofágica no tratamento de abscesso subfrênico e subhepático recorrentes com fístula jejunal, após ressecção de estômago, em um paciente de 41 anos. Ao exame microbiológico, foi identificada a presença de Escherichia coli resistente aos antibióticos. Os bacteriófagos foram preparados e administrados ao paciente e esse passou por cirurgia sem o uso de antibioticoterapia. Durante toda a internação, o paciente recebeu doses de bacteriófagos e, no $33^{\circ}$ dia, obteve alta sem sinal de infecção.

Perepanova et al. (1995) pesquisaram a eficácia da terapia com fagos em casos de infecções urinárias, encontradas entre as infecções hospitalares mais freqüentes. A terapia antibiótica promovia a seleção e disseminação de cepas de microrganismos polirresistentes, reduzindo a defesa intestinal. Um total de 293 cepas foi analisado. Os preparados bacteriofágicos foram usados tanto topicamente como por via oral em 46 pacientes portadores de inflamação urogenital aguda e crônica. A efetividade da terapia se deu em $84 \%$ dos casos, enquanto a eficácia clínica alcançou 92\%. Esses resultados provaram que a terapia bacteriofágica é efetiva e segura no tratamento de infecções urinárias, tanto usada isoladamente quanto associada a antibióticos.

Como muitos pesquisadores, preocupados com o aumento de espécies bacterianas resistentes a diversos agentes antimicrobianos, Merril et al. (1996) estudaram os principais fatores que dificultam a aplicação da terapia bacteriofágica. 
Os autores relacionaram três principais fatores que dificultam o uso dessa terapia: (1) o espectro de hospedeiros bacterianos relativamente estreito; (2) a presença de toxinas nos lisados brutos; e (3) a eliminação rápida de partículas fágicas da circulação sanguínea, principalmente através do sistema reticuloendotelial. $\mathrm{O}$ experimento desenvolvido em ratos utilizou dois tipos de fagos, lambda e P22, e suas cepas bacterianas correspondentes, Escherichia coli e Salmonella typhimurium, respectivamente. Os resultados mostraram que o uso de bacteriófagos específicos para cada cepa bacteriana usada na infecção experimental, além da aplicação de métodos de purificação dos lisados brutos, eliminando toxinas bacterianas, aumentou significativamente a eficácia do tratamento. Quanto à eliminação dos fagos da circulação sanguínea, os autores relataram que esse processo ocorre devido ao reconhecimento de proteínas que compõem a superfície do vírus, através do sistema de defesa do hospedeiro. Selecionando fagos mutantes, que não podem ser retidos pelo sistema reticuloendotelial, os pesquisadores conseguiram melhorar a interação entre fagos e bactérias, aumentando a eficácia antibacteriana dos vírus testados. Os autores concluíram que o aumento dessa eficácia é viável, tornando a terapia bacteriofágica uma possível arma no combate às infecções.

Com o aumento da incidência de bactérias resistentes e o déficit no desenvolvimento de novas classes de antibióticos que as combatessem, Barrow e Soothill (1997) publicaram uma revisão sobre a fagoterapia destacando suas vantagens e desvantagens. Os autores afirmaram que a principal vantagem dos bacteriófagos em relação ao uso da antibioticoterapia reside em sua grande capacidade de replicação, ou seja, uma única dose de fagos seria suficiente no combate à infecção. Além disso, o uso da fagoterapia proporcionaria uma redução no aparecimento de novas cepas resistentes aos antibióticos, e dado o seu 
mecanismo de ação, que elimina somente cepas bacterianas específicas, não ocorreriam alterações na flora bacteriana normal. Por outro lado, essa mesma característica é desvantajosa, já que a maioria dos fagos não atua em casos de infecção mista. Os autores concluíram que o uso da terapia bacteriofágica oferece vantagens únicas sobre antibioticoterapia, lembrando que técnicas de engenharia genética moderna podem ser usadas no desenvolvimento de fagos mais efetivos ou polivalentes.

Carlton (1999) publicou uma revisão sobre fagoterapia descrevendo as principais dificuldades encontradas nos primeiros experimentos feitos entre 1920 e 1950, determinadas pela falta de tecnologia e de métodos científicos adequados, bem como por limitações da própria fisiologia do fago, desconhecida até então. $\mathrm{O}$ autor propõe soluções para problemas como lisogenia, especificidade e presença de anticorpos antifagos, mostrando a possibilidade da aplicação do vírus bacteriano como agente antimicrobiano. Ele destacou ainda a engenharia genética como importante ferramenta, capaz de modificar características desses vírus com o propósito de torná-los mais eficientes. Finaliza sugerindo que a fagoterapia poderá ser usada isoladamente na eliminação de bactérias resistentes aos antibióticos ou associada à antibioticoterapia, em casos nos quais a bactéria ainda for suscetível às drogas.

Tortora, Funke e Case (2000) descreveram o ciclo lítico em cinco estágios distintos. No primeiro estágio, chamado de ancoragem ou adsorção, o fago se liga a um sítio receptor específico, localizado na parede celular bacteriana, interagindo quimicamente por meio de ligações fracas entre o sítio de adsorção e o receptor. No segundo estágio, chamado de penetração, ele injeta seu ácido nucléico dentro da bactéria, através da liberação da enzima lisozima, que destrói uma parte da parede 
bacteriana. Assim que o DNA do bacteriófago alcança o citoplasma da célula hospedeira, inicia-se o terceiro estágio chamado de biossíntese. A síntese protéica do hospedeiro é interrompida, enquanto a síntese do ácido nucléico e das proteínas virais é induzida. A próxima seqüência de eventos consiste na maturação. Componentes virais começam a se organizar espontaneamente, formando partículas completas, plenamente desenvolvidas (virions). O estágio final da multiplicação é chamado de liberação. O termo lise é geralmente usado para esse estágio, quando os fagos rompem a membrana plasmática da célula hospedeira, liberando os bacteriófagos recém-produzidos. Novas células bacterianas nas proximidades são infectadas, e o ciclo de multiplicação se repete.

Pseudomonas aeruginosa é um microrganismo oportunista presente em diversas patologias nos seres humanos e cuja infecção se apresenta muitas vezes resistente aos tratamentos convencionais. A formação de biofilmes espessos por essa espécie bacteriana constitui uma barreira à penetração de quimioterápicos.

Hanlon et al. (2001) investigaram a questão da penetração desse biofilme por bacteriófagos específicos, que atravessam essa camada formada por exopolissacarídeos para alcançar a superfície bacteriana.

Foram usados discos de polimetilmetacrilato de $12 \mathrm{~mm}$ de diâmetro, processados com o intuito de se tornarem suscetíveis a adesão das bactérias. Esses discos foram inoculados com caldo de $P$. aeruginosa por até vinte dias a $37^{\circ} \mathrm{C}$, sendo freqüentemente adicionado meio de cultura, favorecendo o estabelecimento do biofilme. Os discos foram divididos em quatro grupos, segundo o tempo de incubação, que variou entre 5, 10, 15 e 20 dias. Após a formação de diferentes espessuras de biofilme, os discos foram expostos a uma suspensão de fagos líticos específicos para a espécie estudada, na proporção fago/célula bacteriana de 100:1 e 
1000:1. Decorridas 24 horas de incubação, houve redução da quantidade de bactérias em todos os discos, inclusive no grupo de 20 dias de incubação, o qual mostrou uma redução de 2 logaritmos após a aplicação dos fagos.

Esse resultado sugere que os fagos, apesar de não apresentarem motilidade na massa constituída por exopolissacarídeos, conseguem de certa forma reduzir sua viscosidade, permitindo posterior lise bacteriana.

A partir desses resultados, outros testes foram realizados quanto à viscosidade de biofilmes na presença de fagos. Biofilmes comercializados foram expostos aos fagos e então submetidos a testes reológicos (relativos à deformação e fluxo de matéria), cromatografia por infiltração e peso molecular. Houve a diminuição do peso molecular dos biofilmes expostos aos fagos, bem como a redução de mais de $40 \%$ na viscosidade, quando se utilizou suspensão de fagos com uma concentração de $2 \times 10^{8} \mathrm{ufp} / \mathrm{mL}$. Os resultados ainda mostraram que houve uma redução de $99 \%$ das bactérias viáveis, mesmo quando protegidas pelo exopolissacarídeos.

O estudo sugere que essa migração conseguida pelos fagos através da camada de exopolissacarídeos, com o intuito de alcançar bactérias alvo, pode ser facilitada pela redução de sua viscosidade por meio da ação de enzimas produzidas pelas próprias bactérias hospedeiras, quando expostas aos fagos.

Barrow (2001) apresentou um breve histórico sobre o uso de bacteriófagos líticos no combate às doenças infecciosas, considerando seu uso tanto em animais como em seres humanos. Baseando-se nos resultados de suas pesquisas com animais infectados por Escherichia coli, o autor concluiu que a fagoterapia mostrou melhor efetividade profilática e terapêutica quando comparada à antibioticoterapia. Deixou claro que enquanto houver antibióticos disponíveis e bactérias suscetíveis a 
essas drogas, a terapia com fagos não será o tratamento de escolha. Contudo, infecções nas quais há presença de microrganismos resistentes, como Staphylococcus aureus, Staphylococcus epidermidis e Enterococcus faecalis, o uso da fagoterapia deve ser considerado.

O alto índice de mortalidade entre pacientes com queimaduras graves, levou Lazareva et al. (2001) a avaliarem os resultados clínicos e laboratoriais do tratamento de queimaduras por meio de comprimidos contendo bacteriófagos. $\mathrm{O}$ estudo mostrou que a fagoterapia promoveu a desinfecção das feridas, normalização da temperatura corporal e conseqüentemente, diminuição da mortalidade. O exame bacteriológico das secreções obtidas das áreas afetadas após o tratamento revelou baixa presença de estafilococos e estreptococos, e nenhuma presença de Escherichia coli, microrganismos esses, isolados antes do tratamento. Houve também normalização, estatisticamente significante, nos níveis celulares do sistema imunológico. Esses resultados demonstraram efeito positivo no tratamento de pacientes portadores de queimaduras, com medicações a base de fagos.

Em 2003, Inal faz uma revisão da literatura sobre fagoterapia, analisando as vantagens e desvantagens de sua aplicação em relação aos antibióticos, bem como sua utilização em animais e seres humanos.

Quanto a suas vantagens e desvantagens, o autor faz uma comparação mostrada nos quadros abaixo: 


\begin{tabular}{|c|c|}
\hline \multicolumn{2}{|c|}{ VANTAGENS } \\
\hline Fagoterapia & Antibioticoterapia \\
\hline $\begin{array}{l}\text { - alta especificidade, atingindo uma } \\
\text { bactéria em particular. }\end{array}$ & $\begin{array}{l}\text { - apresenta amplo espectro, não } \\
\text { necessitando de identificação prévia } \\
\text { das bactérias envolvidas na infecção. }\end{array}$ \\
\hline $\begin{array}{l}\text { - administração em dose única, já que } \\
\text { os fagos se propagam enquanto houver } \\
\text { bactérias presentes. }\end{array}$ & \\
\hline $\begin{array}{l}\text { - atenuação da virulência das bactérias } \\
\text { que se tornam resistentes ao fago. }\end{array}$ & \\
\hline $\begin{array}{l}\text { - rápido isolamento de um novo fago, } \\
\text { quando ocorre a resistência (dias). }\end{array}$ & \\
\hline - baixo custo & \\
\hline
\end{tabular}

\begin{tabular}{l|l}
\hline \multicolumn{2}{|c|}{ DESVANTAGENS } \\
\hline \multicolumn{1}{|c|}{ Fagoterapia } & \multicolumn{1}{c|}{ Antibioticoterapia } \\
\hline $\begin{array}{l}\text { - necessita de identificação prévia para } \\
\text { isolamento de fago específico ou para o } \\
\text { preparo de um coquetel a base de } \\
\text { fagos. }\end{array}$ & $\begin{array}{l}\text { - administração em múltiplas doses, } \\
\text { associadas a efeitos colaterais e } \\
\text { surgimento de possíveis infecções } \\
\text { secundárias por fungos. }\end{array}$ \\
\hline & $\begin{array}{l}\text { - ao contrário da fagoterapia, ao } \\
\text { apresentar resistência a bactéria } \\
\text { torna-se mais patogênica. }\end{array}$ \\
\hline & $\begin{array}{l}\text { - seu uso destrói também a flora } \\
\text { comensal }\end{array}$ \\
\hline & $\begin{array}{l}\text { o desenvolvimento de um novo } \\
\text { antibiótico e sua comercialização, } \\
\text { pode levar anos. }\end{array}$ \\
\hline & -alto custo \\
\hline
\end{tabular}

O autor ainda descreve as soluções para os principais obstáculos apresentados pela fagoterapia. Quanto à presença de anticorpos que possam eliminar os fagos administrados em animais e seres humanos, o uso de suspensões a base de diferentes partículas virais isoladas para uma mesma espécie bacteriana, 
facilitaria sua aplicação sistêmica. Já a eliminação rápida dos fagos pelo baço e sistema reticuloendotelial, ainda está sendo pesquisada.

O texto aborda ainda a preocupação na utilização de uma medicação viva, mas lembra que vacinas, tão difundidas nos dias de hoje, também consistem de microrganismos vivos atenuados. Além disso, os fagos estão presentes naturalmente em alimentos consumidos, água potável, oceanos, rios e mesmo no trato gastrointestinal de seres humanos.

O autor concluiu que apesar dos fagos apresentarem inúmeras vantagens no controle de infecções, seu mecanismo de ação in vivo necessita de pesquisas mais aprofundadas.

A presença de fagos para enterococos em saliva humana foi observada por Bachrach et al. (2003). Os autores coletaram amostras de saliva de 31 doadores, buscando por fagos para Streptococcus sobrinus, Streptococcus mutans, Streptococcus salivarius, Actinomyces viscosus e Enterococcus faecalis, microrganismos que fazem parte da ecologia da cavidade oral e de canais radiculares. Foram feitas duas coletas subseqüentes com intervalos de um mês e um ano. Somente fagos para E. faecalis foram encontrados em 7 amostras e continuaram presentes na segunda amostra (1 ano após a primeira). Os autores puderam concluir que a presença e estabilidade dos fagos para $E$. faecalis em saliva humana aponta para uma participação direta desses na microbiota da cavidade oral e que devam ser considerados na prevenção de insucessos dos tratamentos endodônticos, já que $E$. faecalis está diretamente associado às infecções persistentes do sistema de canais radiculares. A incidência relativamente alta $(22 \%)$ de fagos para esse microrganismo em saliva humana mostra, que esses fagos 
controlam a população dessa bactéria oportunista, modulando sua disseminação para outros locais.

Bactérias como Streptococcus pneumoniae estão se tornando altamente resistentes aos antibióticos e por esse motivo novas drogas antimicrobianas, ou mesmo diferentes meios no combate à infecção, estão sendo pesquisados.

Loeffler, Djurkovic e Fischetti (2003) usaram uma enzima lítica (Cpl-1) de bacteriófago específico para $S$. pneumoniae, via intravenosa, para tratamento de bacteriemia pneumocócica em ratos. Uma dose de $2000 \mu \mathrm{g}$ da enzima reduziu o número de colônias bacterianas de $\log (10)$ 4,70 ufc/mL para níveis não detectáveis $[<\log (10)$ 2,00 ufc/mL], em um período de 15 minutos. Essa dose administrada 1 hora depois da infecção promoveu $100 \%$ de cura em 48 horas, enquanto que apenas $20 \%$ de cura ocorreu no controle (sem a aplicação da enzima). A enzima Cpl-1 também foi efetiva como medicação tópica nasal, impedindo a colonização dessa região pela bactéria estudada. Na conclusão do estudo, os autores afirmaram que enzimas bacteriofágicas são antimicrobianos extremamente efetivos e reapresentam uma poderosa arma no combate às infecções por bactérias resistentes.

Existe ainda na literatura, um número restrito de trabalhos sobre o isolamento de fagos a partir da cavidade oral. Hitch, Pratten e Taylor (2004) estudaram a presença de fagos líticos em saliva e placa bacteriana dental, em seres humanos sadios e outros, portadores de doença periodontal. Apesar dos resultados mostrarem a presença de um baixo número de fagos, os pesquisadores conseguiram isolar bacteriófagos para Proteus mirabilis em cultura pura e observaram ainda, que os fagos não participaram diretamente na seleção ou modulação da microbiota da cavidade oral. Os autores destacaram que os 
bacteriófagos devem ser considerados agentes terapêuticos em potencial, principalmente por sua propriedade de penetração e desorganização da placa bacteriana formada por microrganismos produtores de exopolissacarídeos, característica essa, conferida pela presença de enzimas específicas (polissacarídeos depolimerase), que interferem nos processos patogênicos associados à presença de biofilme.

Paisano et al. (2004) investigaram in vitro a ação antimicrobiana de bacteriófagos em dentina humana infectada por Enterococcus faecalis. Foram utilizados 20 dentes unirradiculares humanos, recentemente extraídos, e de proporções equivalentes. As coroas foram removidas e os canais instrumentados até a lima tipo $\mathrm{K}$ de número 45. Os espécimes foram, então, esterilizados; e, após isso, infectados por uma suspensão de E. faecalis ATCC 29212. Em três grupos, foi empregada uma suspensão do vírus obedecendo às seguintes proporções bactériafago: GRUPO I - 1:1; GRUPO II - 1:10; GRUPO III - 10:1. Um quarto grupo (GRUPO IV) foi inoculado com a cultura dos microrganismos e mantido a $37^{\circ} \mathrm{C}$ por 24 horas. Decorrido esse período, os espécimes desse grupo foram inoculados com meio de cultura LB diariamente, durante seis dias, com o propósito de manter condições apropriadas para a penetração das bactérias para o interior dos túbulos dentinários. Em seguida, esses espécimes foram inoculados com a suspensão de fagos e novamente incubados a $37^{\circ} \mathrm{C}$ por 24 horas. Cada grupo foi formado por cinco raízes, sendo duas delas utilizadas como controles positivo e negativo. Diluições seriadas e semeadura foram feitas em triplicata após o término de cada período de incubação. No GRUPO IV, todos os espécimes foram inoculados novamente com meio de cultura LB, e diluições seriadas e semeadura foram realizadas após 24 e 48 horas de incubação a $37^{\circ} \mathrm{C}$. Os resultados mostraram 98,7 
até $100 \%$ de redução do crescimento bacteriano nos espécimes que receberam a suspensão de fagos em comparação a seus respectivos controles positivos, em todos os grupos estudados. Diante desses resultados, concluiu-se que os bacteriófagos foram eficazes na eliminação do microrganismo teste.

A preocupação quanto à interação entre bacteriófagos e células eucarióticas foi analisada por Dabrowska et al. (2005) em uma revisão da literatura sobre fagoterapia.

Uma das propostas dessa revisão, embasada em estudos feitos desde 1940, foi desmistificar o uso da fagoterapia em seres humanos, formados por células mais complexas do que organismos unicelulares.

Sabe-se que fagos não infectam células eucariotas, devido às grandes diferenças moleculares tanto na sua superfície externa (receptores), como na maquinaria interna necessária para que aconteça a replicação desses vírus. Apesar disso, os autores relatam que valendo-se da engenharia genética (técnica do phage display) é possível modificar fagos para que esses interajam e mesmo infectem células de organismos superiores, com o objetivo de introduzir uma seqüência de genes capazes de codificar uma nova característica ou função. Embora essa infecção ocorra, nunca foi observada replicação de fagos no interior dessas células.

Os autores ainda destacam que animais e seres humanos são fortemente expostos a inúmeros fagos durante toda a vida, dado confirmado pela presença de anticorpos contra esses vírus na circulação e tecidos de diversos órgãos. Isso mostra que o meio oferecido por esses organismos é favorável ao ciclo lítico dos fagos e que a fagoterapia pode ser considerada como método de tratamento, principalmente nos casos de infecções provocadas por microrganismos resistentes aos antibióticos. 
A preocupação com a incidência de infecções causadas por Pseudomonas aeruginosa multirresistente aos antibióticos de última geração, revitalizou a idéia de se utilizar uma medicação composta por fagos específicos, no tratamento e prevenção de doenças infecciosas causadas por essa bactéria.

Dzuliashvili et al. (2007) desenvolveram uma medicação experimental a partir de 5 fagos virulentos para P. aeruginosa (CF1/1; CF1/7; P.a.N1; P.a.N2; P.a.N4), realizando também testes quanto ao seu espectro, atividade lítica, potencial terapêutico, estabilidade e virulência. Testes in vitro e in vivo (ratos brancos) confirmaram seu efeito antimicrobiano na eliminação de 206 diferentes espécies de P. aeruginosa (99,5\% das cepas testadas). Testes pré-clínicos dessa medicação em animais, ainda mostraram que sua capacidade antimicrobiana foi maior em comparação aos índices obtidos quando da utilização de antibióticos a base de ciprinol, que promoveu 50 a $80 \%$ de redução bacteriana.

Os índices alcançaram $100 \%$ de eficácia quando os pesquisadores associaram a aplicação da fagoterapia com o antibiótico citado.

As pesquisas e seus resultados apresentados mostram a preocupação com o aumento da resistência bacteriana aos quimioterápicos, abrindo um novo caminho à fagoterapia principalmente em casos onde já se esgotaram as alternativas para controle de sinais e sintomas característicos dos processos infecciosos persistentes.

Tendo em conta o até aqui exposto parece bastante aceitável o desenvolver de estudos sobre a possibilidade de aplicação de terapia bacteriofágica em Odontologia e especificamente, no caso desta pesquisa, de aplicação ao tratamento endodôntico. 


\section{PROPOSIÇÃO}

É proposta deste estudo investigar in vitro a ação antimicrobiana de bacteriófagos específicos ao Enterococcus faecalis ATCC e a Enterococcus faecalis obtidos de isolados clínicos.

Adicionalmente, ainda é objetivo desta pesquisa buscar o desenvolvimento de um lisado híbrido polivalente para eliminação de diferentes cepas dessa espécie bacteriana, quando presentes no interior de canais radiculares de dentes humanos. 


\section{MATERIAL E MÉTODOS}

\subsection{Material}

$\stackrel{\leftrightarrow}{\rightarrow}$ ácido fórmico (J.T. Baker Solusorb. México, México).

$\stackrel{4}{4}$ adesivo a base de resina epóxi Araldite ${ }^{\circledR}$ Profissional 10 minutos (Brascola Ltda Brasil).

$\stackrel{4}{\rightarrow}$ agarose (Sigma-Aldrich Corporation $-S^{t}$. Louis, Missouri, USA).

$\stackrel{4}{\rightarrow}$ agitador mecânico de tubos (Fisher Vortex Genie 2, cat. nํ 12-812, Fisher Scientific Inc., USA).

$\stackrel{\leftrightarrow}{\leftrightarrow}$ álcool absoluto (Merck. Darmstadt, Germany).

$\stackrel{\leftrightarrow}{\leftrightarrow}$ álcool isoamílico (Merck. Darmstadt, Germany).

$\stackrel{\leftrightarrow}{\rightarrow}$ autoclave vertical MOD 103 (Fabbe - Brasil).

$\stackrel{\leftrightarrow}{\rightarrow}$ brometo de etídio (Invitrogen - Carlsbad, Califórnia, USA).

$\stackrel{\leftrightarrow}{\text { M }}$ caldo de cultivo EVA Broth (Difco Laboratories - USA) (Anexo G).

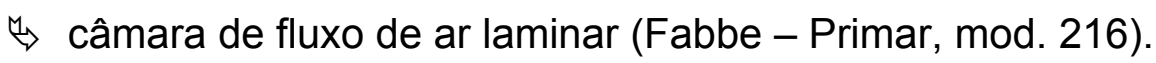

$\stackrel{4}{\rightarrow}$ caneta de baixa rotação (Kavo do Brasil. Joinvile, Paraná).

$\stackrel{\leftrightarrow}{\rightarrow}$ carbonizador de grades (Bal-tec - SCD-005 - TL 17368, Liechtenstein).

$\stackrel{M}{\rightarrow}$ clorofórmio P.A. (MogiGlass. Artigos para laboratórios. Mogi das Cruzes, São Paulo).

$\stackrel{M}{M}$ cones de papel absorvente estéreis calibres 45 e 50 (Endopoints Indústria e Comércio Ltda., Rio de Janeiro). 
$\Leftrightarrow$ conjunto de curetas periodontais $n^{\circ} 17$ e 18 (SS White Artigos Dentários Ltda. Rio de Janeiro).

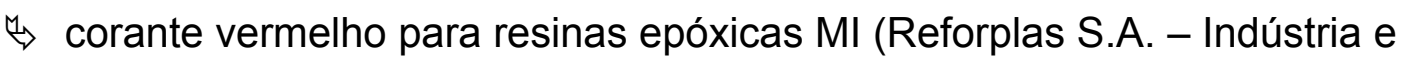
Comércio. São Paulo).

$\Leftrightarrow$ dentes humanos unirradiculares $(n=37)$, oriundos da Disciplina de Cirurgia da Faculdade de Odontologia da Universidade Cidade de São Paulo (UNICID).

$\Leftrightarrow$ destilador de água (Marconi Equipamentos para Laboratório ${ }^{\circledR}$, mod. MA 078/2. Piracicaba, São Paulo).

« discos de aço, granulação 0,7 micra (Wilcos do Brasil Ltda).

$\Leftrightarrow$ EDTA (Sigma-Aldrich Corporation $-S^{t}$. Louis, Missouri, USA).

$\Leftrightarrow$ eosina (Sigma-Aldrich Corporation $-S^{t}$. Louis, Missouri, USA).

$\Leftrightarrow$ Enterococcus faecalis ATCC29212 (Oxoid - São Paulo, SP, Brasil).

$\Leftrightarrow$ Enterococcus faecalis oriundos de isolados clínicos.

${ }^{4}$ espectrofotômetro Spectronic ${ }^{\circledR} 20$ Genesys $^{\mathrm{TM}}$ (Spectronic Instruments, USA).

$\Leftrightarrow$ estantes para tubos de polipropileno (Sigma-Aldrich Corporation $-S^{t}$. Louis, Missouri, USA).

$\Leftrightarrow$ estufa microbiológica (Fabbe - Primar, mod. 216).

$\Leftrightarrow$ estufa para esterilização (Olidef CZ Indústria e Comércio - Brasil).

$\Leftrightarrow$ etanol (Merck. Darmstadt, Germany).

$\Leftrightarrow$ fenol (Merck. Darmstadt, Germany).

$\Leftrightarrow$ filmes radiográficos periapicais (Ektaspeed-Eastman Kodak Company. New York, USA).

« glicerol (USB Corporation. Cleaveland, Ohio, USA).

$\Leftrightarrow$ grades de cobre de 300 mesh (SPI Supplies - Structure Probe, Inc. West Chester, Pennsylvania, USA). 
$\Leftrightarrow$ hematoxilina (Sigma-Aldrich Corporation $-\mathrm{S}^{t}$. Louis, Missouri, USA).

↔ HMDS (Electon Microscopy Sciences. Fort Washington, Pennsylvania, USA).

Æ intermediário para aspiração, cânulas de aspiração 40:20 e agulhas de irrigação 4:10.

$\Leftrightarrow$ isopor com gelo para transporte.

$\Leftrightarrow$ kit coloração de Gram (Newprov Produtos para Laboratório Ltda., Pinhais, Paraná).

$\Leftrightarrow$ lâminas de vidro para microscopia $26 \times 76$ mm (Glasstécnica Comércio de Vidros Ltda., São Paulo).

$\Leftrightarrow$ limas tipo K (Maillefer Ballaigues, Swiss: Cosa Dental Importação Ltda., São Paulo).

$\Leftrightarrow$ limitadores de silicone (Maillefer Ballaigues, Swiss: Cosa Dental Importação Ltda., São Paulo).

$\leftrightarrow$ luvas cirúrgicas estéreis (Madeitex Ind. e Com. de Art. Látex Ltda. - Brasil).

$\leftrightarrow$ meio de cultura Luria-Bertani (Anexo B).

$\Leftrightarrow$ meio de cultura top-agar (Anexo D).

$\Leftrightarrow$ micropipetas $\mathrm{P} 1000 \mu \mathrm{L}, \mathrm{P} 200 \mu \mathrm{L}, \mathrm{P} 40 \mu \mathrm{L}, \mathrm{P} 10 \mu \mathrm{L}$ (Pipetman - Gilson -França).

$\Leftrightarrow$ microscópio eletrônico de transmissão (Leo-906E - Leo Ltd., Cambridge, UK).

$\Leftrightarrow$ microscópio eletrônico de varedura (Leo 430 - Leo Ltd., Cambridge, UK).

공 microscópio ótico de luz (Micronal - Indústria Brasileira).

$\stackrel{4}{4}$ óleo de imersão para microscopia (Niles Biological, Inc., Sacramento, Califórnia, USA).

(4) papel de filtro (Melitta do Brasil - Indústria e Comércio Ltda.).

$\Leftrightarrow$ parafilme $^{\circledR}$ (Pechiney Plastic Packaging, Chicago, USA).

(4) pinça de ponta fina antiestática (Altrade-Divcon, série 2800, São Paulo). 
$\stackrel{\leftrightarrow}{\hookrightarrow}$ pinças de aço inoxidável (SS White Artigos Dentários Ltda).

$\stackrel{\leftrightarrow}{\rightarrow}$ pipeta Pasteur (Sigma-Aldrich Corporation $-S^{\dagger}$. Louis, Missouri, USA).

$\Leftrightarrow$ placas de Petri estéreis (Prolab Comércio de Produtos para Laboratório Ltda. Curitiba, Paraná).

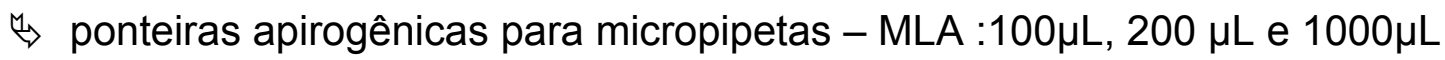
(Sigma-Aldrich Corporation - St. Louis, Missouri, USA).

$\Leftrightarrow$ proteinase K (Sigma-Aldrich Corporation $-\mathrm{S}^{t}$. Louis, Missouri, USA).

$\stackrel{4}{*}$ régua milimetrada metálica (Maillefer Ballaigues, Swiss: Cosa Dental Importação Ltda., São Paulo).

$\Leftrightarrow$ sodium dodecyl sulfate (Invitrogen - Carlsbad, Califórnia, USA).

$\Leftrightarrow$ seringas descartáveis de $10 \mathrm{~mL}$ (BD Industrias Cirúrgicas Ltda. - Brasil).

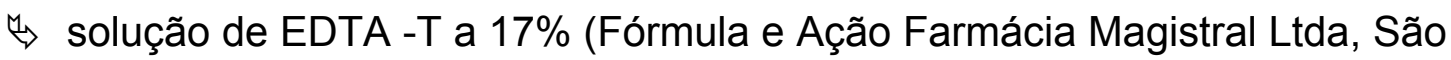
Paulo).

$\Leftrightarrow$ solução de formvar a 1\% (ProSciTech - Thuringowa, Austrália) (Anexo H).

$\stackrel{4}{4}$ solução de fosfotungstato de potássio a $2 \%$ (Anexo F).

$\Leftrightarrow$ solução fisiológica estéril (Laboratório Tayuyna Ltda. - São Paulo, Brasil).

(4) solução reveladora e fixadora GBX (Kodak Brasileira Comércio e Indústria Ltda).

$\Leftrightarrow$ transiluminador UV $20 \times 20$ (Sigma-Aldrich Corporation $-S^{t}$. Louis, USA).

$\stackrel{4}{4}$ tryptic soy agar - TSA (Difco Laboratories - USA) (Anexo E).

$\Leftrightarrow$ tryptic soy broth - TSB (Difco Laboratories - USA) (Anexo C).

$\Leftrightarrow$ tubos de ensaio (Sigma-Aldrich Corporation $-S^{t}$. Louis, Missouri, USA).

$\Leftrightarrow$ tubos de polipropileno MCT-200C de $1000 \mu \mathrm{L}$ e de $500 \mu \mathrm{L}$ (Axygen. Union City, Califórnia, USA).

$\Leftrightarrow$ ultra pure $^{T M}$ Tris (Invitrogen - Carlsbad, Califórnia, USA).

(4) ultra-som Profi III (Dabi Atlante Indústria Médico Odontológica S.A.). 


\subsection{Métodos}

Foram usados padrões rigorosos de assepsia e câmara de fluxo de ar laminar para os procedimentos microbiológicos (Figura 4.1).
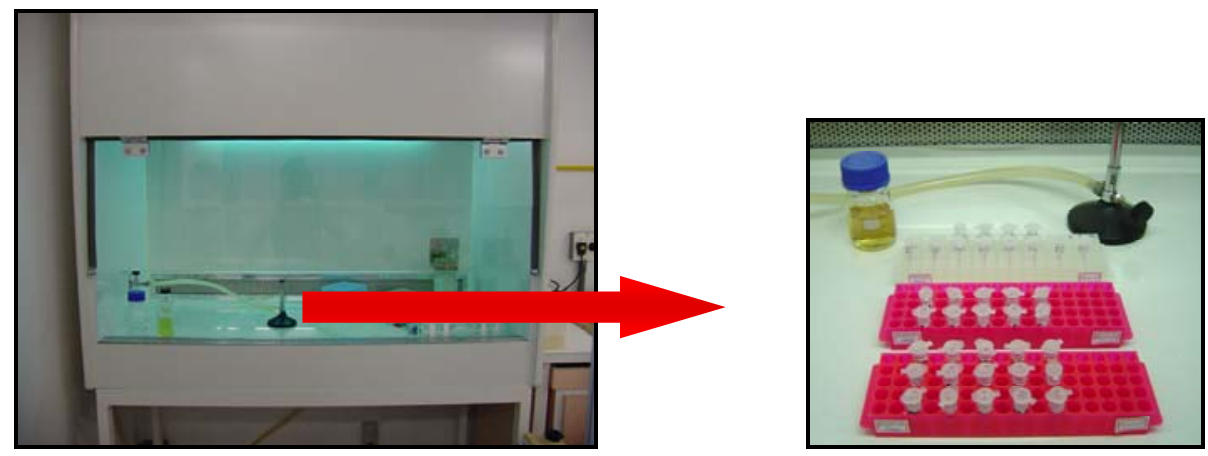

Figura 4.1 - Câmara de fluxo de ar laminar utilizada na realização dos ensaios. No detalhe, estantes contendo os grupos experimentais.

4.2.1 Preparo das suspensões a base de fagos

\subsubsection{1 isolamento de fagos}

Foram utilizados, como cepas propagadoras, suspensões de Enterococcus faecalis ATCC 29212 e de outros 4 Enterococcus faecalis provenientes de isolados clínicos, denominados em função do nome dos pacientes dos quais foram obtidos 
(AD, AND, H e R), todos mantidos em estoque em Tryptic Soy Broth acrescido de glicerol $40 \%$ a $-20^{\circ} \mathrm{C}$.

O método empregado no isolamento dos fagos (Figura 4.2) baseou-se em pesquisas realizadas por Smith e Huggins (1982) e Berchieri Jr, Lovell e Barrow (1991) que utilizaram água de esgoto para sua obtenção.

A amostra de água foi coletada no córrego Pirajussara, (zona Oeste da cidade de São Paulo), que recebe esgoto doméstico e industrial, vindo dos seguintes bairros: Butantã, Jardim Jussara, Jardim Trussardi, Jardim Ademar, Jardim Peri-Peri e Instituto de Previdência. Essa amostra foi transportada ao laboratório em banho de gelo. A seguir, para o volume de $300 \mathrm{~mL}$ da água do córrego, foram adicionados 100 $\mathrm{mL}$ de meio LB (Anexo B) e $100 \mathrm{~mL}$ de meio TSB (Anexo C). Após uma hora de incubação a $37{ }^{\circ} \mathrm{C}$, foram adicionados $3 \mathrm{~mL}$ de 5 diferentes suspensões de Enterococcus faecalis, ATCC 29212 e 4 isolados clínicos dessa bactéria, denominados $A D, A N D, H$ e $R$ (oriundos de dentes portadores de periodontite apical assintomática), preparados previamente em TSB. Decorridas 16 horas de incubação, a $37^{\circ} \mathrm{C}$, foram acrescentados $500 \mu \mathrm{L}$ de clorofórmio para $10 \mathrm{~mL}$ da cultura e essa mistura submetida à centrifugação durante dez minutos, a 7000 rpm. O sobrenadante, acrescido de $100 \mu \mathrm{L}$ de clorofórmio, foi armazenado a $4{ }^{\circ} \mathrm{C}$ (lisado bruto). Uma alíquota dessa suspensão foi adicionada à cultura de cada um dos Enterococcus faecalis, semeados em top-agar (Anexo D) sobre $20 \mathrm{~mL}$ de ágar TSA (Anexo E), com o propósito de selecionar fagos específicos para essas cepas bacterianas. A partir do primeiro isolamento de uma placa de lise, foram preparados novos lisados bacterianos, seguindo o mesmo protocolo acima descrito, até a obtenção de uma suspensão contendo $2 \times 10^{8} \mathrm{ufp} / \mathrm{mL}$ (Figura 4.3), específica para 
cada bactéria estudada. Os lisados utilizados na pesquisa foram nomeados segundo a cepa propagadora correspondente: ATCC, AD, AND, H e R.

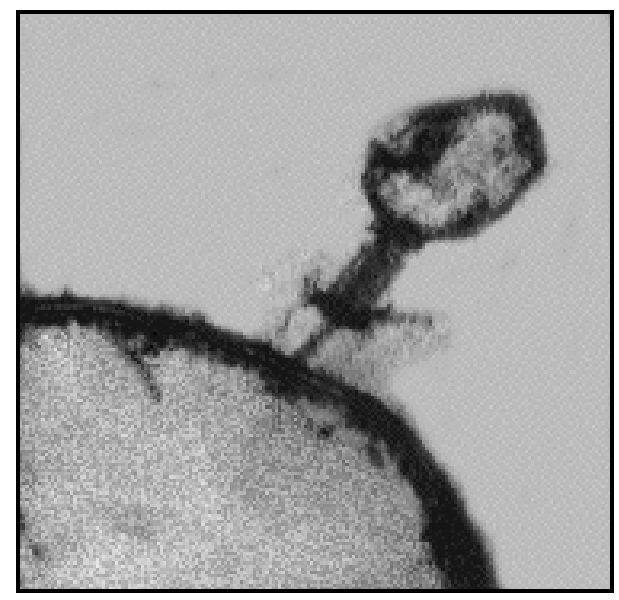

Figura 4.2 - Fotomicrografia de um fago denominado T4, infectando uma célula hospedeira de Escherichia coli, a título de ilustração (http//www.dform.com/projects/t4/virus.html; data da consulta: $14 / 04 / 07)$

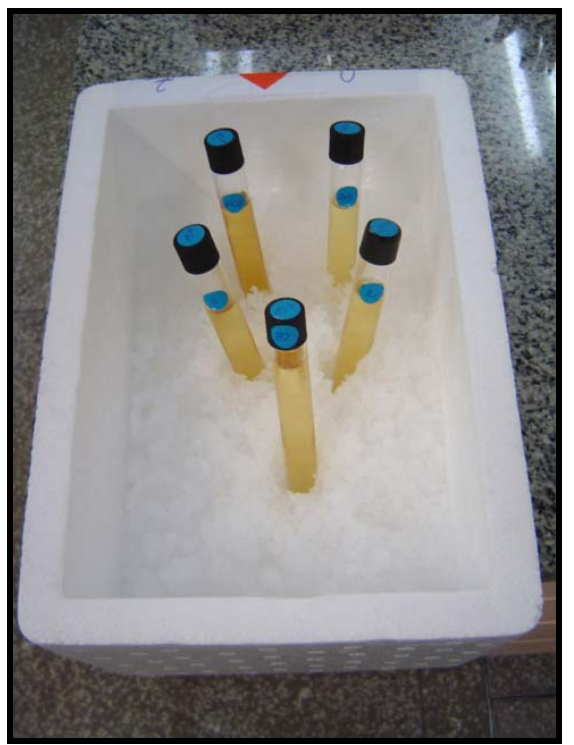

Figura 4.3 - Tubos de ensaio contendo as suspensões de fagos específicos, cuja titulação era de $2 \mathrm{x}$ $10^{8} \mathrm{ufp} / \mathrm{mL}$, em banho de gelo 
4.2.1.2 titulação da suspensão de fagos

No dia anterior à titulação, foram preparadas suspensões de cada um dos Enterococcus faecalis a partir de uma unidade formadora de colônia (ufc), em meio TSB.

Sobre $20 \mathrm{~mL}$ de ágar TSA, verteu-se uma mistura contendo $3 \mathrm{~mL}$ de top-agar e $100 \mu \mathrm{L}$ da suspensão de Enterococcus faecalis, preparada previamente. Após a solidificação, alíquotas de $10 \mu \mathrm{L}$ de diversas diluições $\left(10^{-2}, 10^{-4}, 10^{-5}, 10^{-6}\right.$ e $\left.10^{-7}\right)$ da suspensão de fagos foram depositadas na superfície do meio de cultura. Esse protocolo se repetiu para cada cepa estudada. Decorridas 16 horas de incubação, a $37^{\circ} \mathrm{C}$ foi observada presença de halos transparentes, indicativos de lise bacteriana. Cada halo, denominado placa de lise, corresponde, teoricamente, a uma única partícula viral. Portanto, a concentração de fagos nas suspensões, medida pelo número de placas de lise em determinada diluição, pode vir expressa em unidades formadoras de placas por mililitros (ufp/mL).

4.2.1.3 caracterização dos fagos isolados

Os fagos são classificados de acordo com sua morfologia, tipo de ácido nucléico e presença ou não de envelope. 


\subsubsection{1 caracterização morfológica macroscópica}

A observação das placas de lise formadas a partir dos diferentes lisados, mostrou pouca variedade quanto à morfologia. Foram observadas placas de lise de tamanhos que variaram desde puntiformes até $3 \mathrm{~mm}$ de diâmetro, apresentando ainda, bordos lisos e regulares (Figura 4.4).

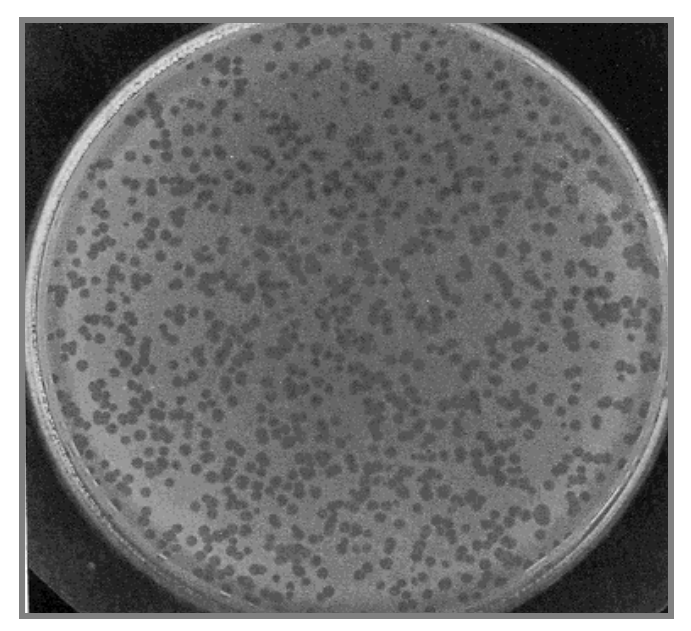

Figura 4.4 - Placas de lise obtidas de um dos lisados

\subsubsection{2 caracterização morfológica microscópica}

A morfologia ultra-estrutural dos 5 fagos correspondentes às cepas ATCC, $A D, A N D, H$ e $R$, foi observada pela técnica de coloração negativa descrita por Brenner e Horne (1959), em microscópio eletrônico de transmissão (Leo-906E).

A adesão das partículas virais foi efetuada em grades de cobre de 300 mesh (unidade de medida da malha - Figura 4.5), recobertas por película de formvar e 
carvão. Para o preparo das grades foi usada uma solução de formvar em água, onde as grades foram mergulhadas, formando uma película semelhante a um acetato em uma de suas superfícies. No vácuo, promovido por equipamento especial (carbonizador), essas grades sofreram uma descarga de carvão para aumentar sua resistência ao impacto do feixe eletrônico, e foram então armazenadas em lâminas de vidro comuns, com a superfície brilhante para cima. Foi vertido $20 \mu \mathrm{L}$ de solução de fosfotungstato de potássio a $2 \%, \mathrm{pH} 6,4$ (Anexo $\mathrm{F}$ ), sob a região de lise sem diluição, na placa correspondente a cada fago titulado. Com a própria ponteira, coletou-se uma alíquota de $20 \mu \mathrm{L}$ dessa suspensão, vertendo-a em um nicho da caixa de ponteira recoberta com parafilme. Sob essa gota foi colocada a grade com a superfície brilhante para baixo, em contato com a solução fosfotungstato e fagos. A grade permaneceu na superfície e não inserida no interior da gota, para evitar bolhas, durante 10 minutos. Verteu-se $20 \mu \mathrm{L}$ do fosfotungstato em outros 3 nichos para posteriores lavagens. Após os 10 minutos, o excesso de solução foi removido, tocando a borda da grade delicadamente em um papel de filtro. A grade foi então delicadamente passada pelas três gotas subseqüentes, para lavagem da superfície, removendo o excesso de coloração. Todas as grades foram armazenadas em temperatura ambiente, sem muita movimentação, até a secagem. As grades foram examinadas em um microscópio eletrônico de transmissão Leo-906E, operando a 80 kV (Figura 4.6). Foram realizadas fotomicrografias e calculadas as medidas dos fagos com ajuda de paquímetro de precisão. A classificação dos fagos e seus morfotipos foram descritos conforme Ackermann et al. (1997) (ANEXO M) e Regenmortel et al. (2000). 


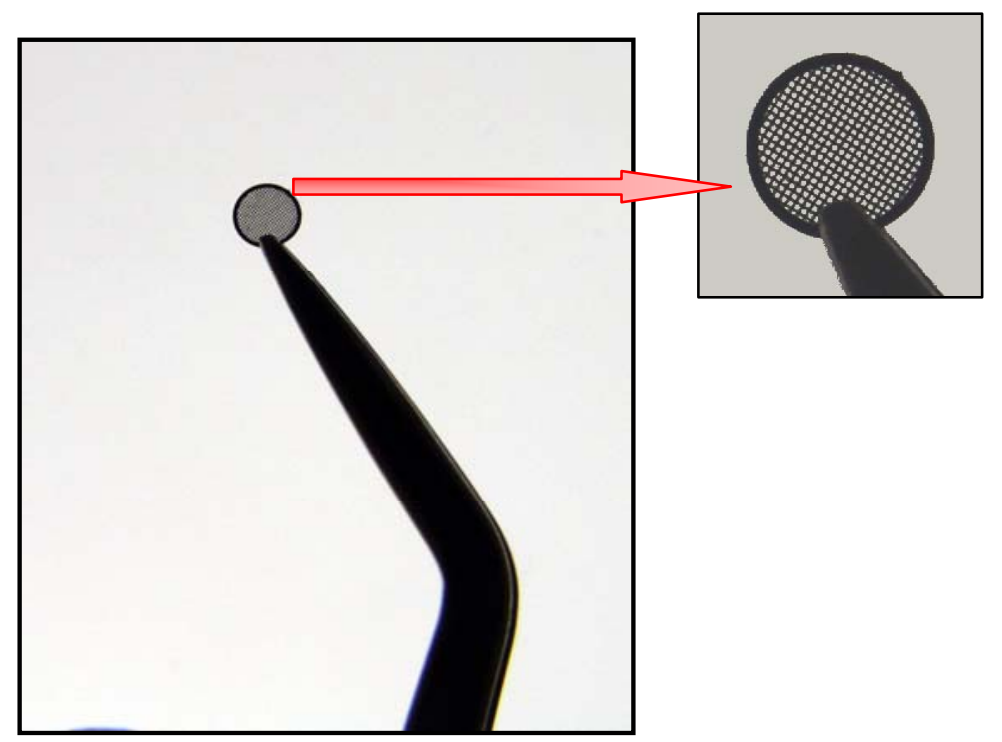

Figura 4.5 - Grade de cobre de 300 mesh para microscopia de transmissão

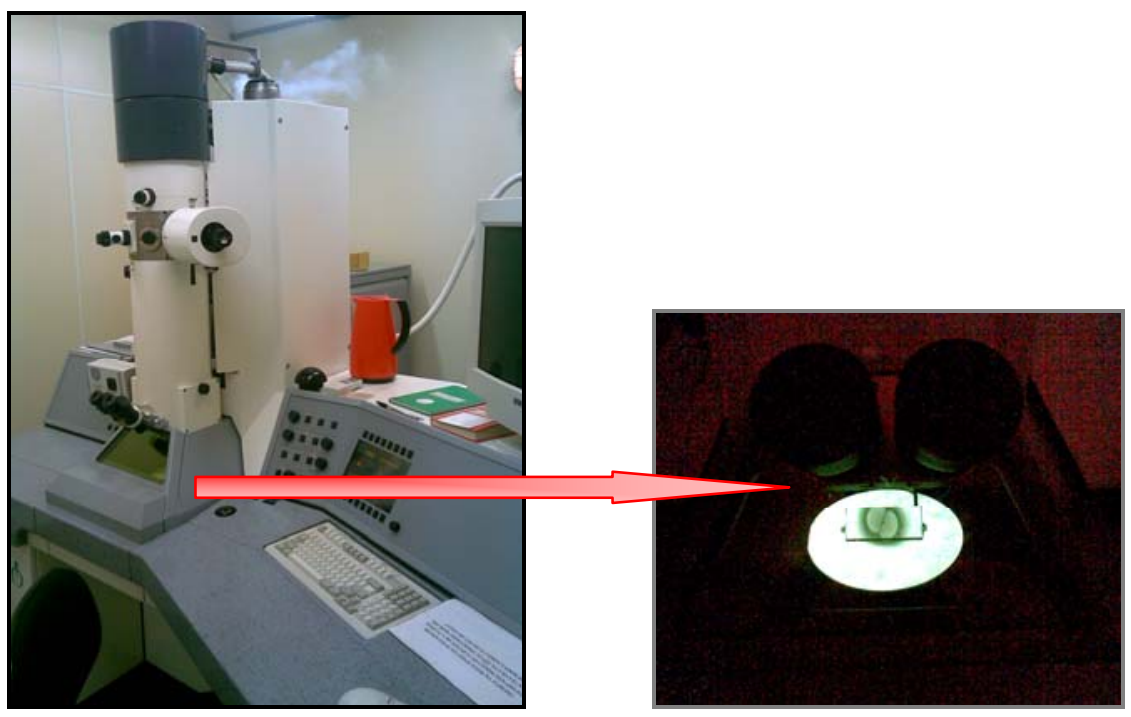

Figura 4.6 - Microscópio eletrônico de transmissão Leo-906E. No detalhe, imagem de Enterococcus faecalis

A análise da ultra-estrutura, por MET, revelou que todos os fagos pertenciam à ordem Caudovirales, família Siphoviridae, sendo a cepa de Enterococcus faecalis ATCC 29212, de morfotipo San21 e os demais, H-19J (Figura 4.7 a 4.17). 


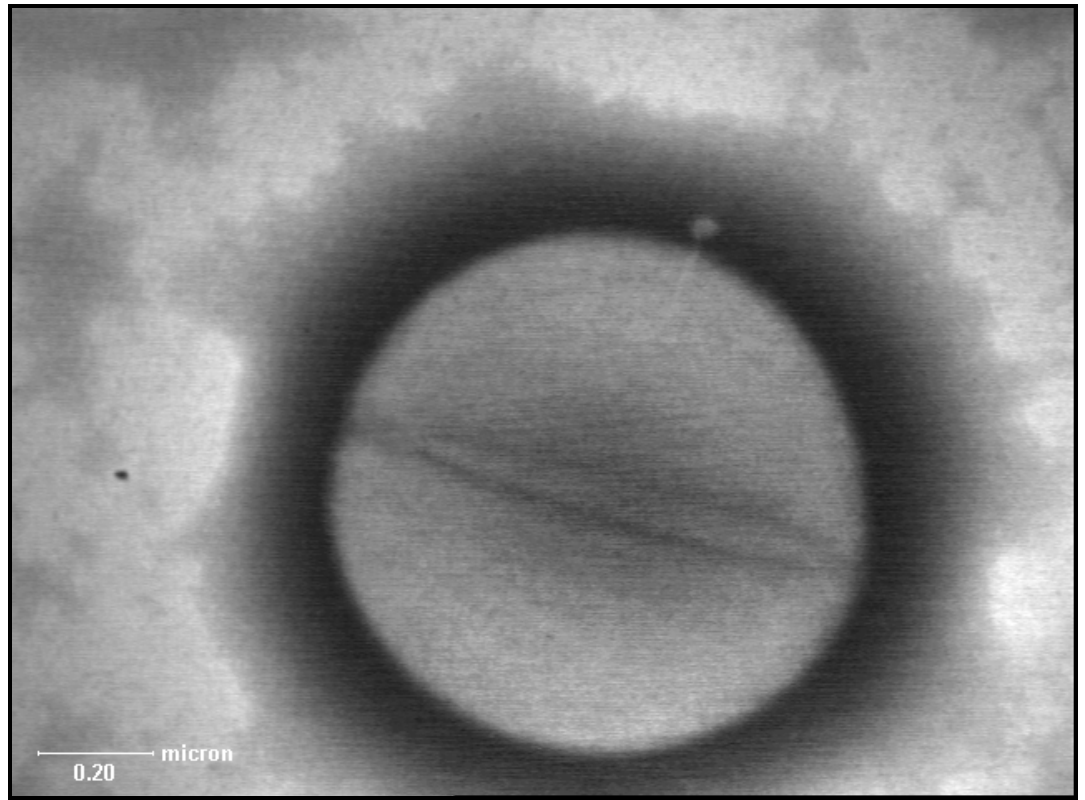

Figura 4.7 - Fotomicrografia do fago ATCC, infectando uma célula bacteriana de Enterococcus faecalis (aumento de 18.000x)

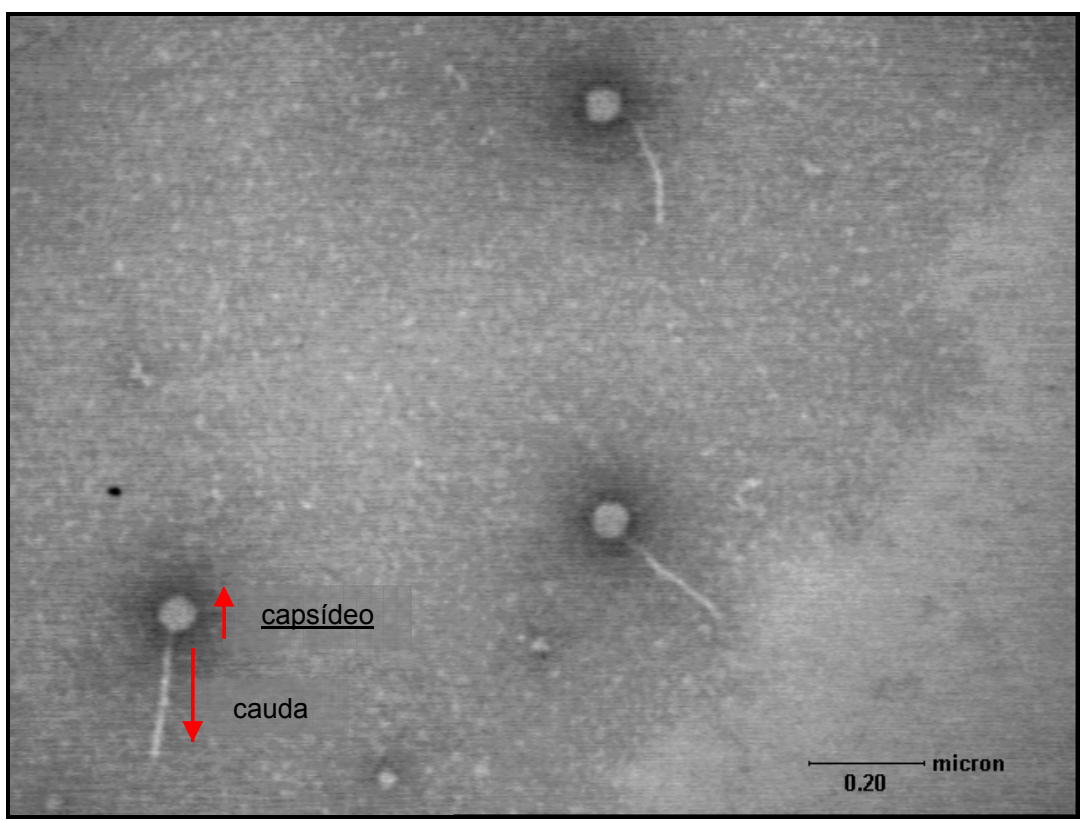

Figura 4.8 - Fotomicrografia do fago ATCC. Comprimento do capsídeo $65,44 \mathrm{~nm}$, largura do capsídeo $60,23 \mathrm{~nm}$, comprimento da cauda 179,31 nm, largura da cauda 11,8 nm (aumento de 20.000x) 


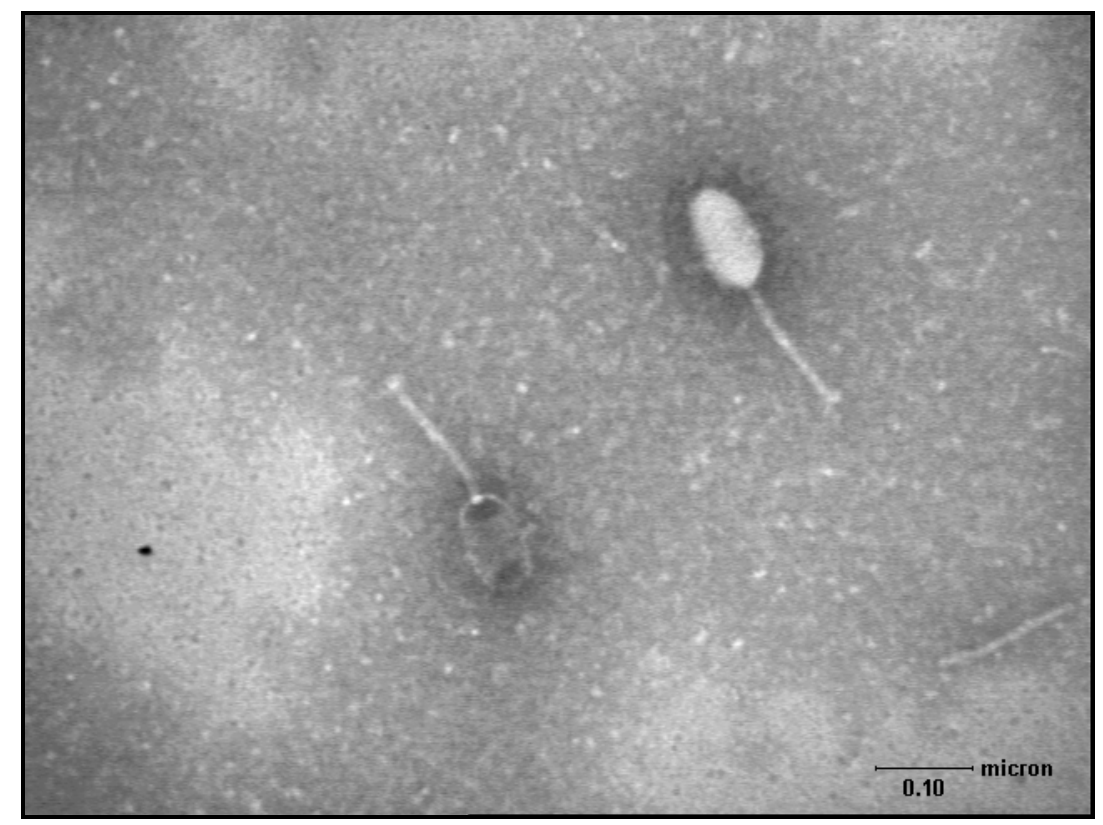

Figura 4.9 - Fotomicrografia do fago AD. Capsídeo com ausência de ácido nucléico, sugerindo que houve infecção de uma célula bacteriana hospedeira, ao lado de um fago completo (aumento de 30.000x)

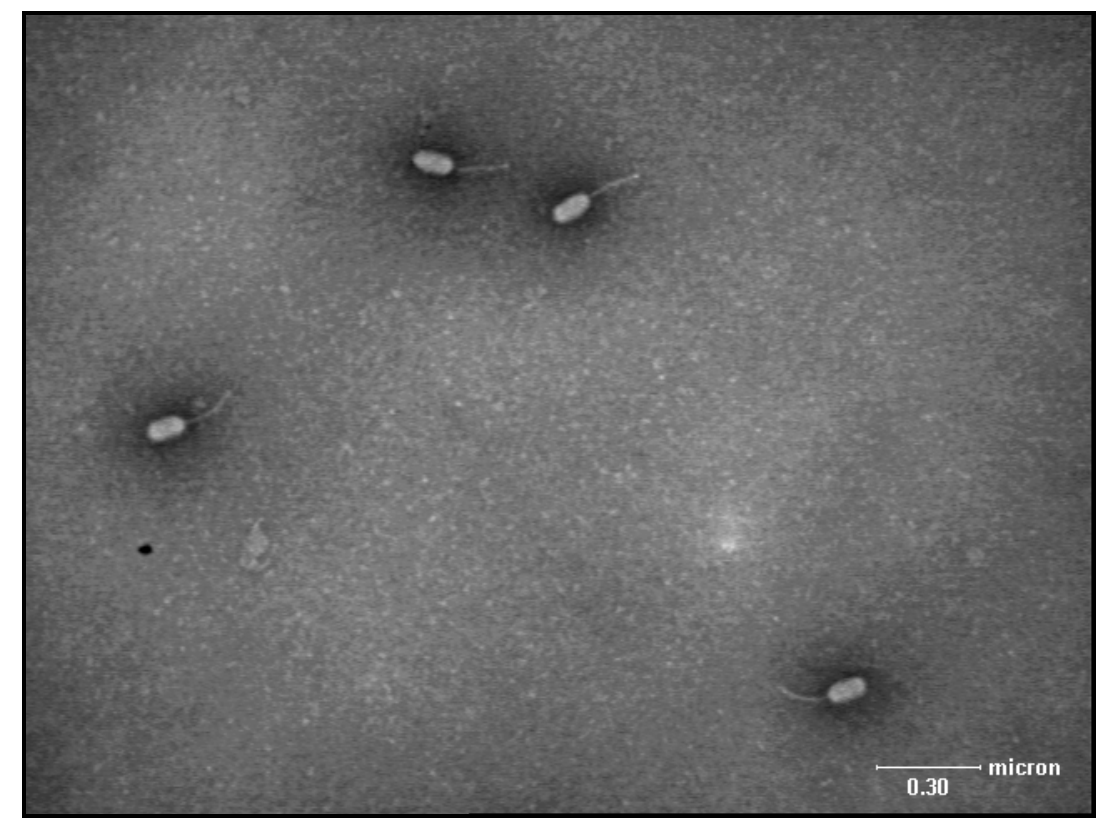

Figura 4.10 - Fotomicrografia do fago AD. Comprimento do capsídeo 131,6 nm, largura do capsídeo $62,26 \mathrm{~nm}$, comprimento da cauda $159,9 \mathrm{~nm}$, largura da cauda $16 \mathrm{~nm}$ (aumento de 18.000x) 


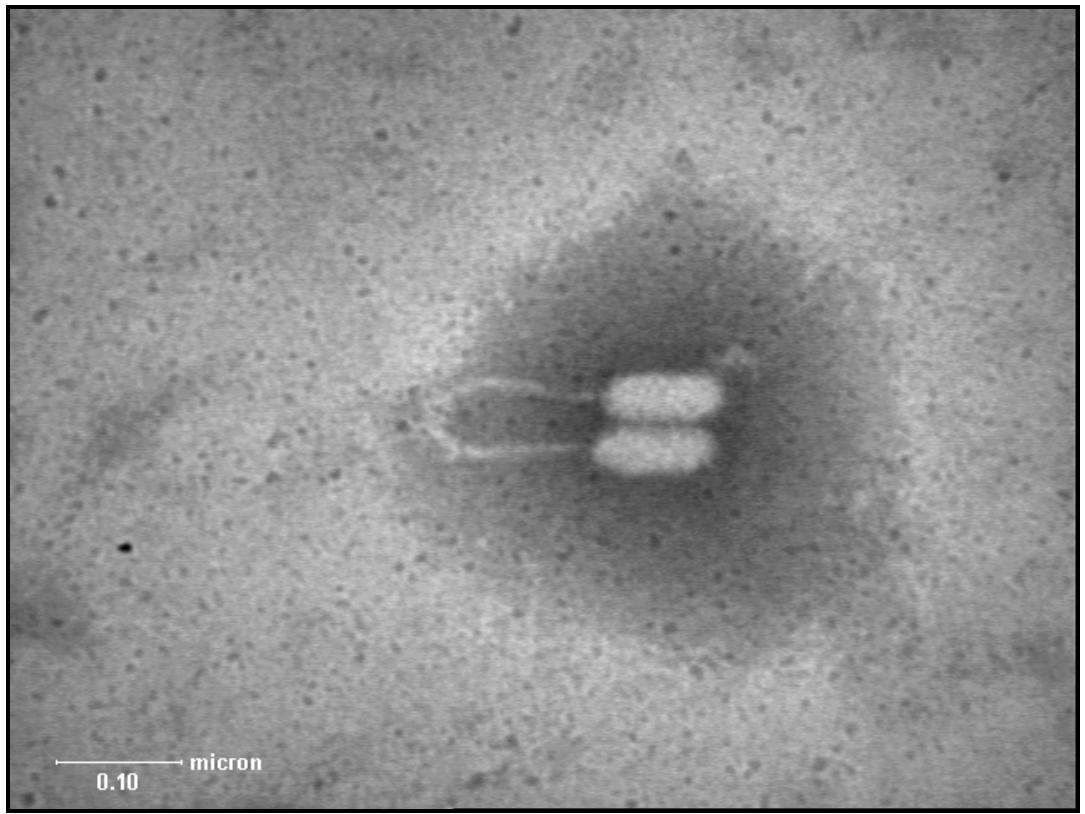

Figura 4.11 - Fotomicrografia do fago AND. Comprimento do capsídeo $108 \mathrm{~nm}$, largura do capsídeo $46 \mathrm{~nm}$, comprimento da cauda $154 \mathrm{~nm}$, largura da cauda 7,6 nm (aumento de 30.000x)

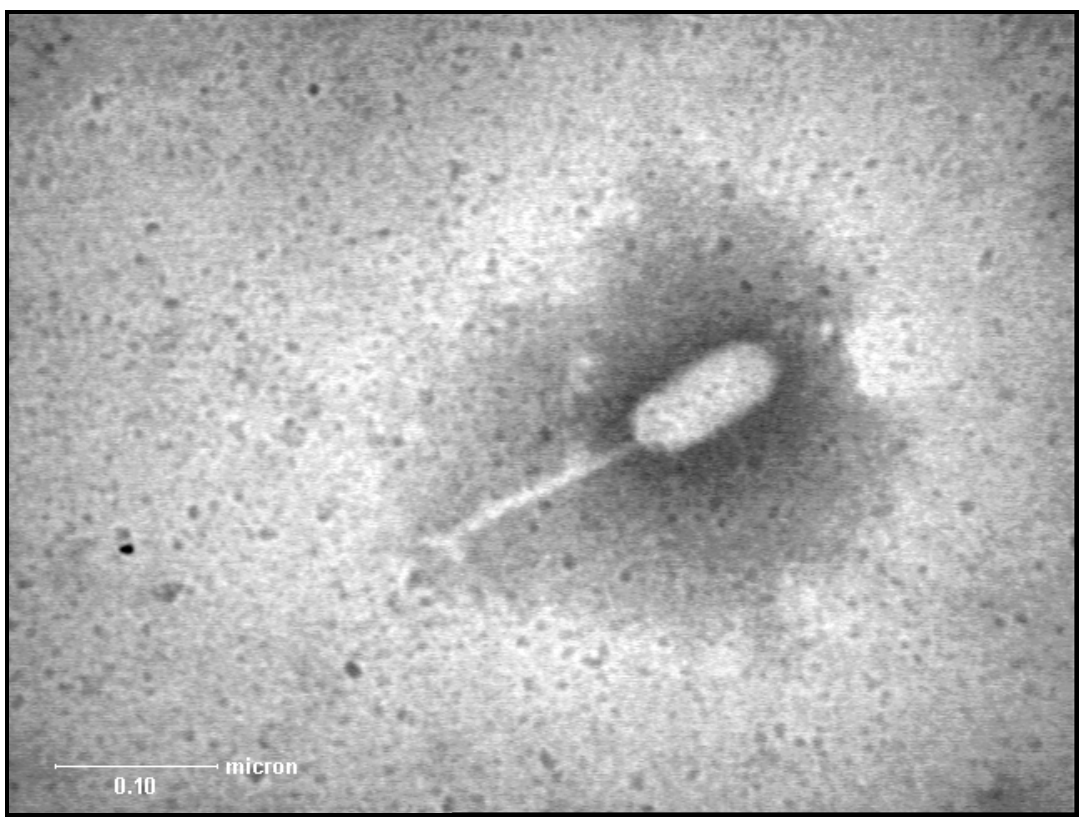

Figura 4.12 - Fotomicrografia do fago AND. Comprimento do capsídeo 106,19 nm, largura do capsídeo $45 \mathrm{~nm}$, comprimento da cauda $138 \mathrm{~nm}$, largura da cauda 10,4 nm (aumento de $35.000 x)$ 


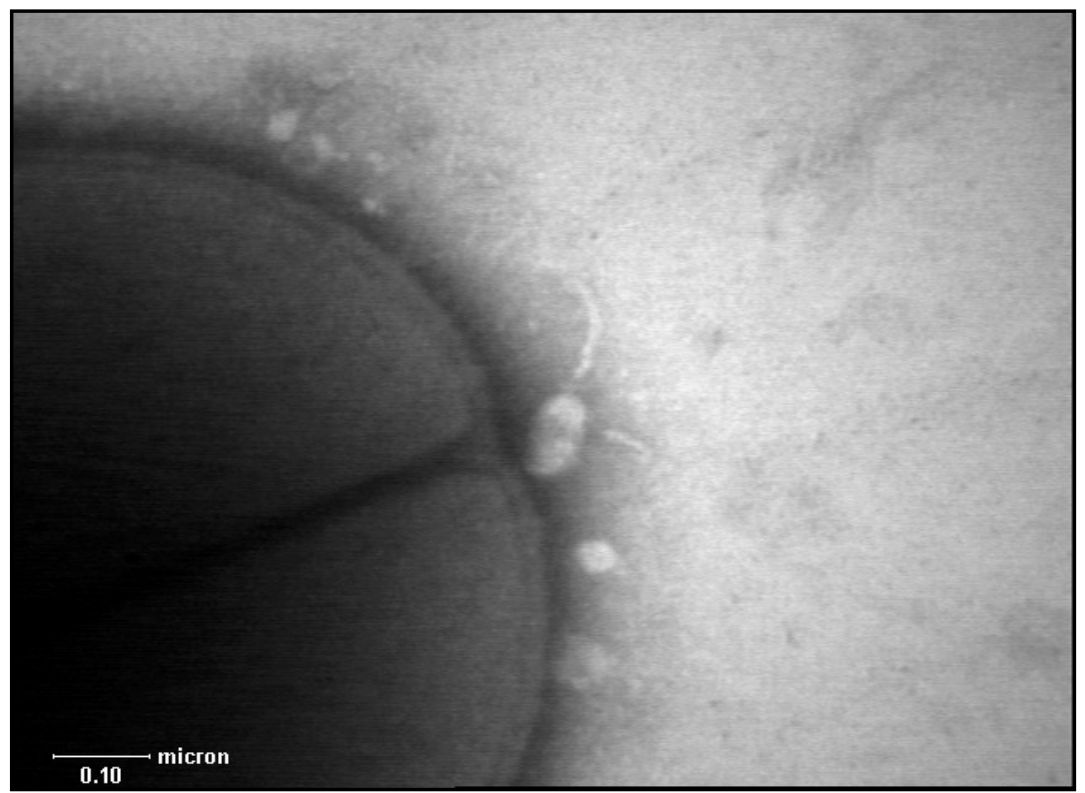

Figura 4.13 - Fotomicrografia do fago H. Comprimento do capsídeo 95,12 nm, largura do capsídeo $49,8 \mathrm{~nm}$, Comprimento da cauda 101,9 nm, largura da cauda 15,6 nm (aumento de $30.000 x)$

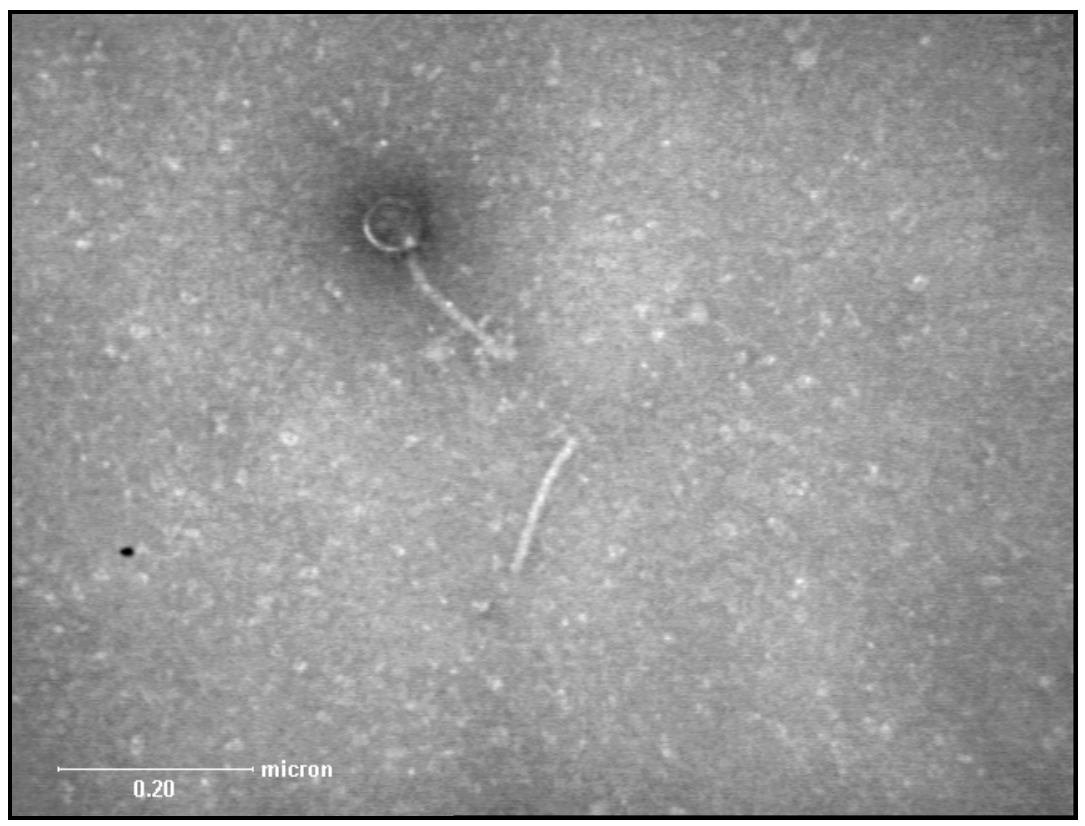

Figura 4.14 - Fotomicrografia do fago H. Capsídeo com ausência do ácido nucléico, sugerindo que houve infecção de uma célula bacteriana hospedeira (aumento de 30.000x) 


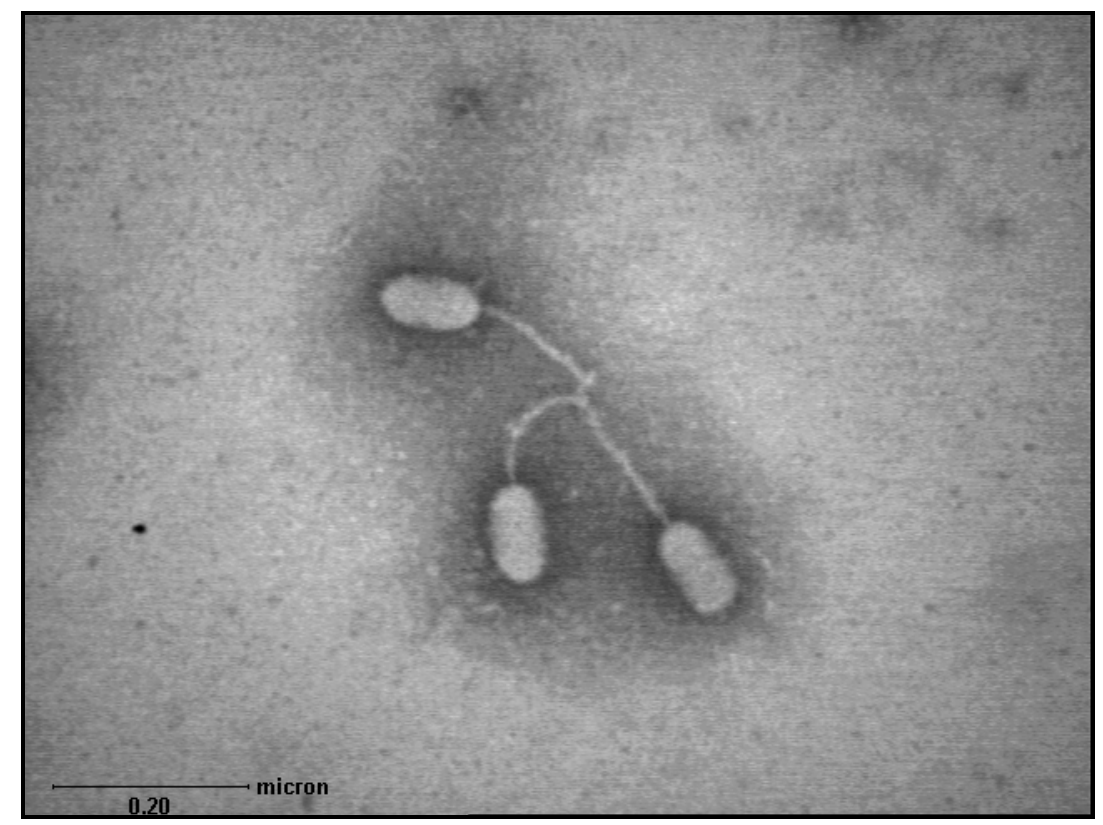

Figura 4.15 - Fotomicrografia do fago R. (aumento de 30.000x)

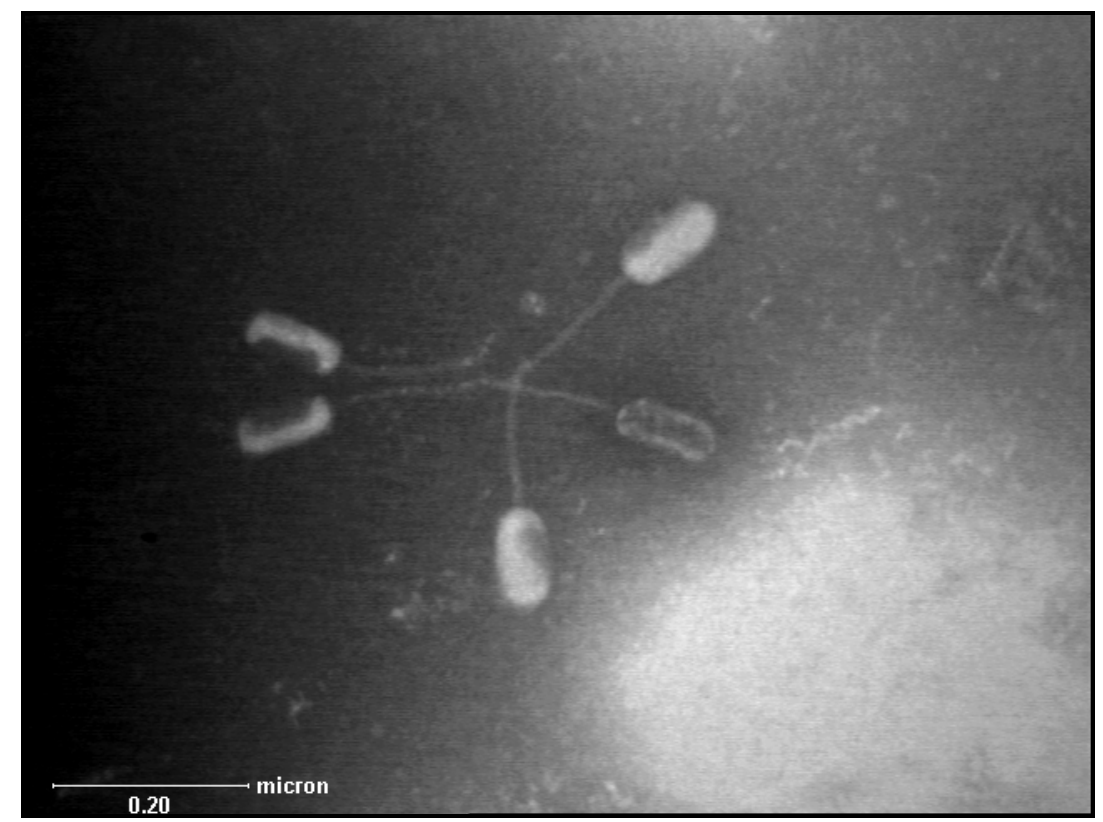

Figura 4.16 - Fotomicrografia do fago R. Comprimento do capsídeo $98,37 \mathrm{~nm}$, largura do capsídeo $53,84 \mathrm{~nm}$, comprimento da cauda 128,9 nm, largura da cauda 11,38 nm (aumento de 30.000x) 


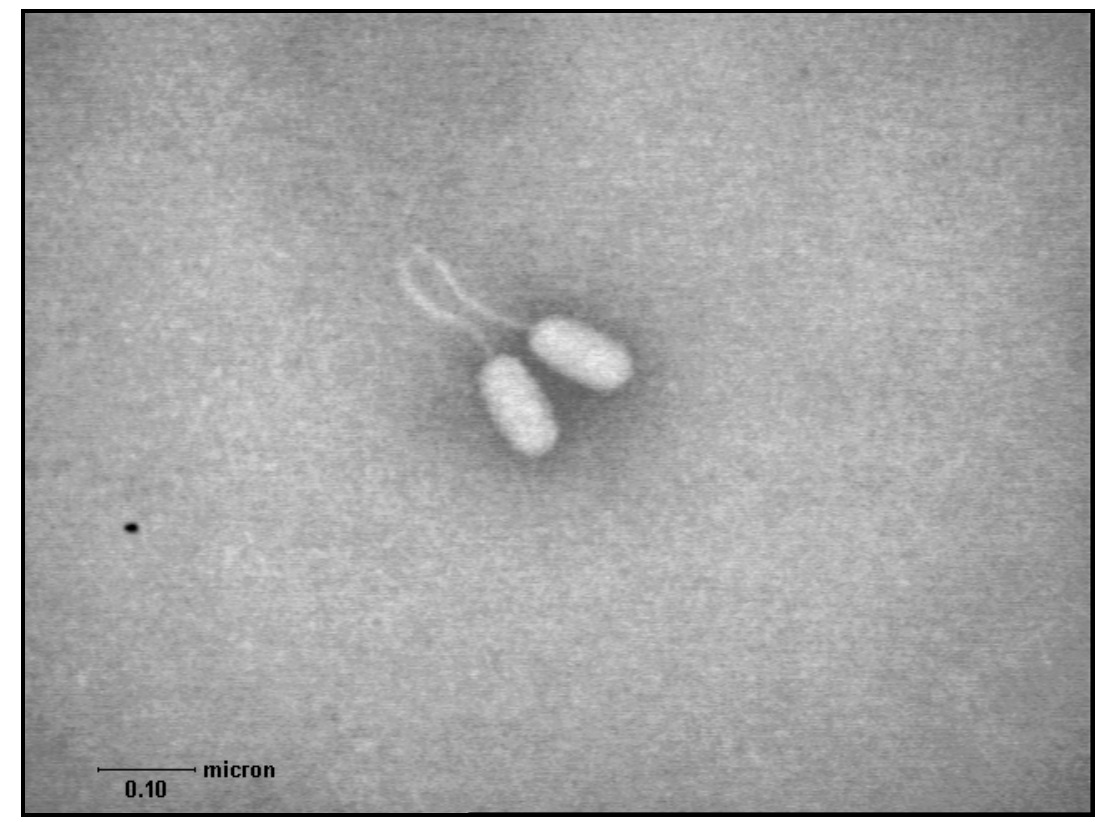

Figura 4.17 - Fotomicrografia do fago R. Observação da cauda longa e flexível de dois fagos $R$ (aumento de 30.000x)

\subsubsection{3 caracterização genômica dos fagos}

a - extração do material genético viral

O material genético viral foi extraído utilizando a técnica descrita por Sambrook, Fritsch e Maniatis (1989) para bacteriófago $\lambda$. A extração foi realizada em triplicatas partindo de suspensões com títulos aproximados de $10^{6}$ a $10^{8} \mathrm{ufp} / \mathrm{mL}$.

A um volume de $600 \mu \mathrm{L}$ da suspensão de bacteriófagos foi adicionado 0,2 volumes do tampão de lise STEP (SDS, Tris, EDTA e Proteinase K). A suspensão foi homogeneizada e incubada a $50{ }^{\circ} \mathrm{C}$ por 15 minutos. Um volume igual de fenol saturado com $10 \mathrm{mM}$ de Tris- $\mathrm{HCl} \mathrm{pH} 8,0$ e 1,0 mM de EDTA foi adicionado a suspensão, homogeneizada e centrifugada a $8000 \mathrm{rpm}$ por 10 minutos a $4{ }^{\circ} \mathrm{C}$. A 
fase aquosa foi transferida e homogeneizada com igual volume de fenol-clorofórmioálcool isoamílico (25:24:1) saturado com $10 \mathrm{mM}$ de Tris $\mathrm{pH}$ 8,0 e 1mM de EDTA. Após a centrifugação a 8000 rpm, a fase aquosa foi removida e purificada com um volume igual de clorofórmio-álcool isoamílico (24:1). O material genético foi precipitado com 2 volumes de etanol 95\% e ressuspendido em tampão TE (Anexo K). As alíquotas para análise foram estocadas a $-20^{\circ} \mathrm{C}$.

A integridade do material de cada amostra foi determinada através de eletroforese em gel de agarose 1\% em tampão TAE (Tris acetato EDTA) (Anexo J). O marcador de peso molecular lambda DNA - Hind III (Boerhinger Mannheim) foi utilizado para estimar o tamanho e concentração do material analisado. A eletroforese foi realizada em uma corrente elétrica contínua de 100 volts por aproximadamente 40 minutos. O gel foi corado em solução de brometo de etídio ( 0,5 $\mu \mathrm{g} / \mathrm{mL}$ ) e visualizado em transiluminador de ultravioleta.

b - caracterização do material genético do fago

O tipo de material genético do bacteriófago foi identificado através da incubação com DNase I ou RNase A. 
b1 - incubação com DNase I

Amostras contendo cerca de $1 \mu \mathrm{g}$ de material genético extraído conforme descrito acima foram incubadas com $1 \mathrm{U}$ de DNase I (GE Heathcare) por 30 minutos a $37^{\circ} \mathrm{C}$. A enzima foi inativada por calor e as amostras foram resolvidas em gel de agarose $1 \%$, utilizando como marcador de peso molecular $150 \mathrm{ng}$ de Lambda Hind III e 150 ng de DNA ladder plus (Fermentas).

b2 - incubação com RNase A

Amostras contendo cerca de $1 \mu \mathrm{g}$ de material foram incubadas com RNase A $10 \mathrm{mg} / \mathrm{mL}$ (Fermentas) por 30 minutos a $37^{\circ} \mathrm{C}$. As amostras foram posteriormente resolvidas em gel de agarose $1 \%$ utilizando como marcador de peso molecular 150 ng de Lambda Hind III e 150 ng de DNA ladder plus (Fermentas).

Amostras de DNA extraídos dos bacteriófagos (concentrações de 0,5 a $1 \mu \mathrm{g}$ ) foram submetidos à digestão pelas enzimas de restrição Eco RI, Eco RV, Bam HI, Hinf I, Pst I e Hind III (Boerhinger Mannheim), incubados a $37^{\circ} \mathrm{C}$ por 1 hora utilizando-se o tampão adequado para cada enzima, segundo metodologia descrita por Sambrook, Fritsch e Maniatis (1989).

As bandas obtidas pela digestão do genoma dos fagos foram reveladas através de eletroforese em gel de agarose a $1 \%$, sendo a eletroforese realizada a 
100 volts por aproximadamente 40 minutos. As amostras foram coradas em solução de brometo de etídio $(0,5 \mu \mathrm{g} / \mathrm{mL})$ por 10 minutos (Figura 4.18 e 4.19$)$.

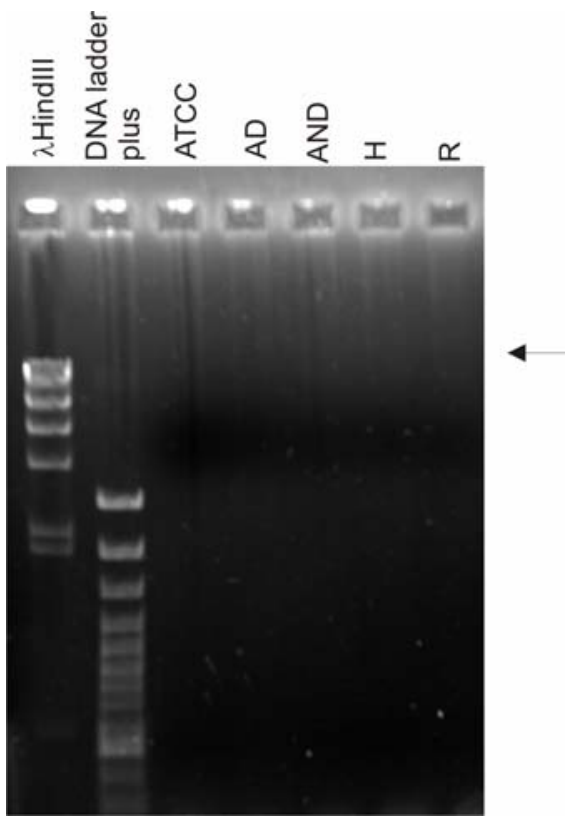

Figura 4.18 - Digestão do genoma do fago com enzima DNAse

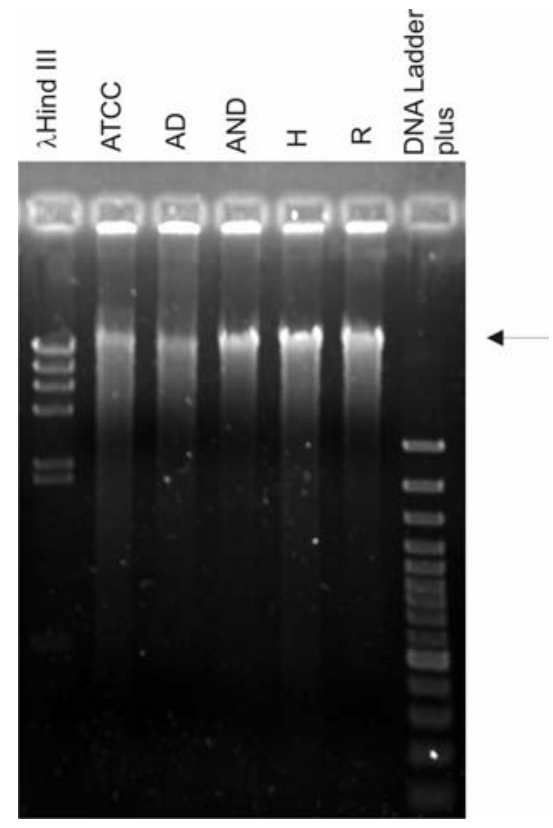

Figura 4.19 - Digestão do genoma do fago com enzima RNAse 
O padrão das bandas obtidas mostrou que o genoma dos fagos foi digerido completamente na presença de DNase I, o que mostra que o material genético de todos eles é composto por DNA.

4.2.2 Curva de crescimento do Enterococcus faecalis em meio EVA

Construiu-se uma curva de crescimento de Enterococcus faecalis ATCC 29212 em meio EVA (Anexo G).

A partir de um inóculo de $100 \mu \mathrm{L}$ em $10 \mathrm{~mL}$ de EVA, a cultura foi mantida a 37 ${ }^{\circ} \mathrm{C}$. Quando atingiu as absorbâncias de 0,$1 ; 0,2 ; 0,4 ;$ e 0,6 aferidas em espectrofotômetro a $546 \mathrm{~nm}$, alíquotas foram diluídas e semeadas em ágar TSA para contagem do número de unidades formadoras colônias (ufc). Os resultados foram representados em gráfico (Figura 4.20) e os cálculos basearam-se na seguinte fórmula:

Número de bactérias $\times 10^{8} / \mathrm{mL}=\frac{\text { absorbância }}{0,23}$

absorbância

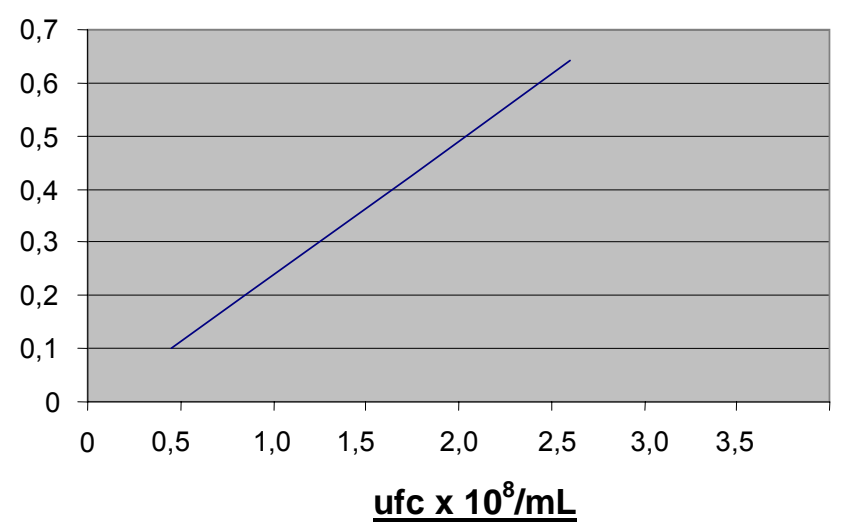

Figura 4.20 - Curva de crescimento do Enterococcus faecalis em meio EVA 


\subsubsection{Preparo da cultura bacteriana}

Foram utilizadas cepas de Enterococcus faecalis ATCC 29212 e 4 isolados clínicos dessa bactéria, denominados AD, AND, $H$ e $R$ (oriundos de dentes portadores de periodontite apical primária assintomática), mantidas em estoque em TSB acrescido de glicerol $40 \%$ a $20{ }^{\circ} \mathrm{C}$. Uma alíquota de $100 \mu \mathrm{L}$ de cada cepa em estoque foi transferida para $5 \mathrm{~mL}$ de caldo EVA e incubadas a $37^{\circ} \mathrm{C}$ por 24 horas. Placas de TSA foram então semeadas para obtenção de unidades formadoras de colônias. Um novo caldo bacteriano foi obtido de uma unidade formadora de colônia, em meio EVA (Figura 4.21), e teve sua densidade óptica ajustada no espectrofotômetro (Figura 4.22), em 0,4 a $546 \mathrm{~nm}$, correspondente a $1,7 \times 10^{8}$ ufc/mL.

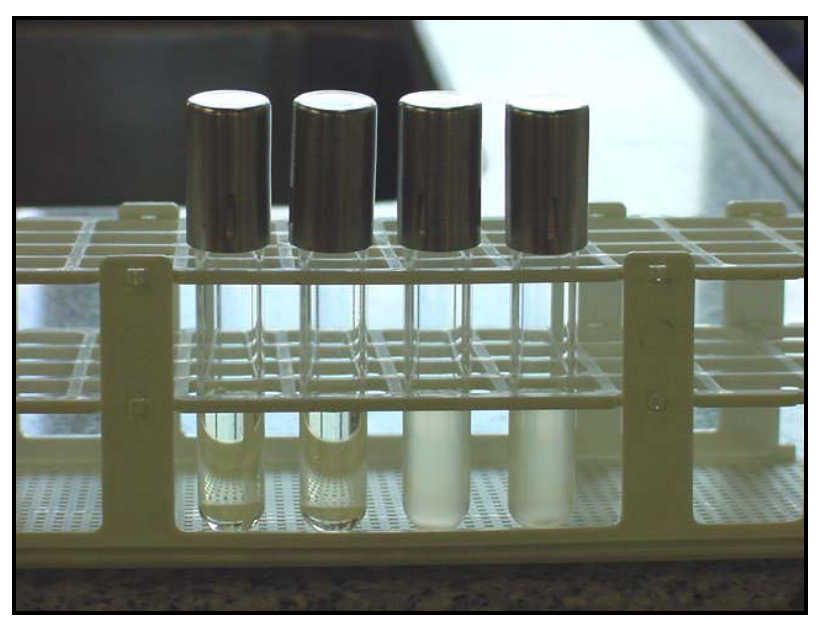

Figura 4.21 - Detalhe do desenvolvimento dos microrganismos, observado pela turbidez do meio EVA, após incubação a $37^{\circ} \mathrm{C}$ por 24 horas 


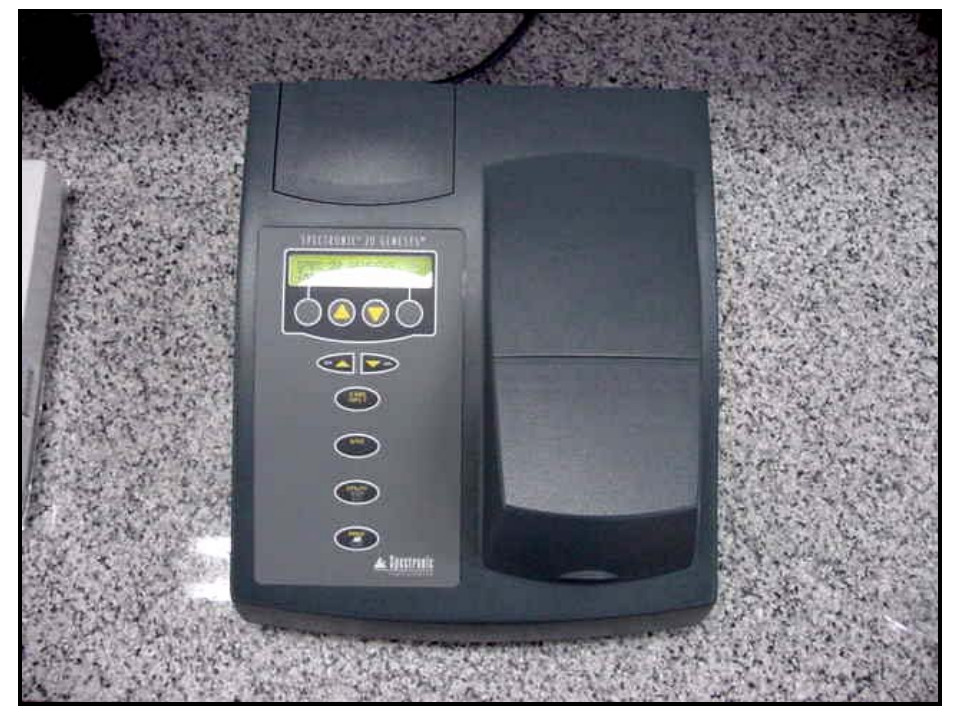

Figura 4.22 - Espectrofotômetro utilizado para mensuração de absorbância na padronização e obtenção dos inóculos

4.2.4 Multiplicidade de infecção e cinética de tratamento com fagos

A multiplicidade de infecção (multiplicity of infection - MOI) relaciona a quantidade mínima de fagos necessária para que ocorra a lise de uma determinada quantidade de bactérias, enquanto a cinética diz respeito ao tempo necessário para que isso ocorra.

De acordo com os resultados obtidos por Paisano et al. (2004), foi adotada a proporção 1:1 $(\mathrm{MOI}=1,0)$, suficiente na eliminação de Enterococcus faecalis ATCC 29212, em um período de 3 horas. Portanto, uma absorbância de 0,4, correspondente a $1,7 \times 10^{8} \mathrm{ufc} / \mathrm{mL}$, foi fixada para cada uma das cepas, proporcional aos títulos dos lisados. 


\subsubsection{Preparo dos espécimes}

\subsubsection{1 seleção dos dentes}

O projeto de pesquisa foi submetido ao Comitê de Ética em Pesquisa da Faculdade de Odontologia da Universidade de São Paulo (CEP-FOUSP) e aprovado em 04 de outubro de 2007.

Foram selecionados 37 dentes humanos unirradiculares, portadores de rizogênese completa, da Disciplina de Cirurgia da Faculdade de Odontologia da Universidade Cidade de São Paulo (UNICID), extraídos por razões diversas. Esses dentes, de proporções aproximadas, tiveram suas coroas removidas com o uso de discos de aço acoplados à caneta de baixa rotação, sob constante refrigeração.

Cálculo dental e outros eventuais resíduos aderidos às superfícies radiculares externas foram criteriosamente removidos com o auxílio de curetas periodontais. Posteriormente, tomadas radiográficas foram realizadas a fim de verificar a existência de canal único e reto, calcificações ou reabsorções internas, os dois últimos considerados fatores excludentes. 


\subsubsection{2 seqüência de preparo dos espécimes}

Os canais foram preenchidos com solução fisiológica esterilizada e, com o uso de lima $\mathrm{K}$ de número 15 , foi realizado o esvaziamento de seus conteúdos. $\mathrm{O}$ comprimento de trabalho foi determinado pela introdução de lima tipo $\mathrm{K}$ de fino calibre com limitador de silicone até que sua guia de penetração alcançasse o forame apical. Foi subtraído $1 \mathrm{~mm}$ desse valor, aferido com régua milimetrada. Estabelecida essa extensão longitudinal, foi realizado o preparo químico-cirúrgico com limas tipo $\mathrm{K}$ e irrigação com $5 \mathrm{~mL}$ de solução fisiológica estéril a cada troca de instrumento, preparando-se os canais até a lima de número 45. A irrigação final foi realizada com $5 \mathrm{~mL}$ de solução de EDTA-T seguida de $100 \mathrm{~mL}$ de soro fisiológico sob ação de vibração ultra-sônica. A superfície externa das raízes foi então impermeabilizada com adesivo a base de resina epóxi Araldite $^{\circledR}$, acrescido de corante. Após a instrumentação, os dentes foram colocados em frascos contendo solução fisiológica e esterilizados em autoclave a $121^{\circ} \mathrm{C}$ durante vinte minutos sob 1 psi. Após esses procederes, os espécimes foram secados com auxílio de compressas de gaze e cones de papel absorvente previamente esterilizados, e inseridos em tubos de polipropileno autoclavados com auxílio de pinças metálicas previamente esterilizadas (Figuras 4.23). 


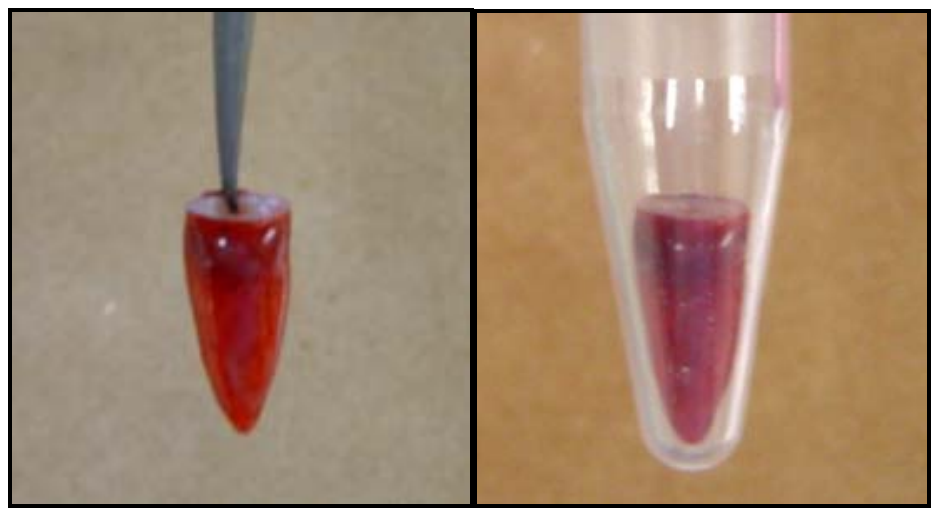

Figura 4.23 - Espécime preparado e impermeabilizado em sua superfície externa com adesivo Araldite ${ }^{\circledR}$ corado e, o mesmo, acondicionado em tubo de polipropileno

\subsubsection{Inoculação dos espécimes}

\subsubsection{1 experimento 1}

Um total de 25 espécimes foram divididos aleatoriamente em 5 grupos. Cada grupo era constituído de 5 raízes, das quais três foram inoculadas com cultura de cada um dos microrganismos (ATCC, AD, AND, $H$ e R) separadamente, e suspensão de fagos correspondentes. Duas outras raízes foram usadas como controle positivo e negativo, sendo preenchidas, respectivamente, com cultura de cada um dos microrganismos e com meio EVA. Todos os grupos foram inoculados com bactérias e fagos na proporção 1:1 (MOI = 1), acorde Paisano et al. (2004). As suspensões acondicionadas em frascos do tipo Eppendorf contendo $60 \mu \mathrm{L}$ de Enterococcus faecalis e $60 \mu \mathrm{L}$ do respectivo fago, foram homogeneizadas em agitador de tubos e uma alíquota de $20 \mu \mathrm{L}$ foi inoculada em cada canal com auxílio de ponteiras capilares acopladas a micropipetas (Tabela 4.1). Os espécimes foram 
mantidos a $37^{\circ} \mathrm{C}$, durante três horas. Após esse período, alíquotas de $10 \mu \mathrm{L}$ foram retiradas de cada espécime com ponteiras de ponta capilar, sendo realizadas diluições seriadas seguidas de semeadura em placas contendo ágar TSA, para contagem do número de ufc/mL (Figura 4.24 e 4.26).

Tabela 4.1 - Volumes dos inóculos usados nos espécimes do Experimento 1

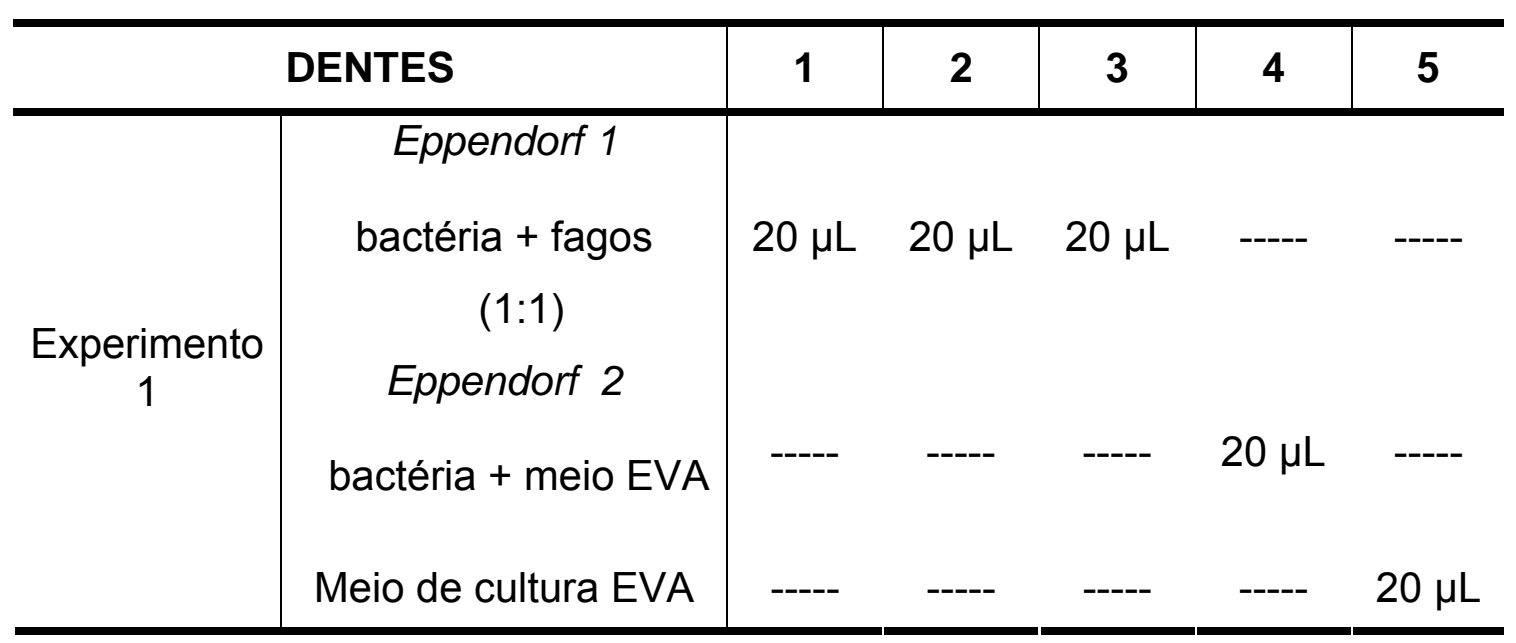




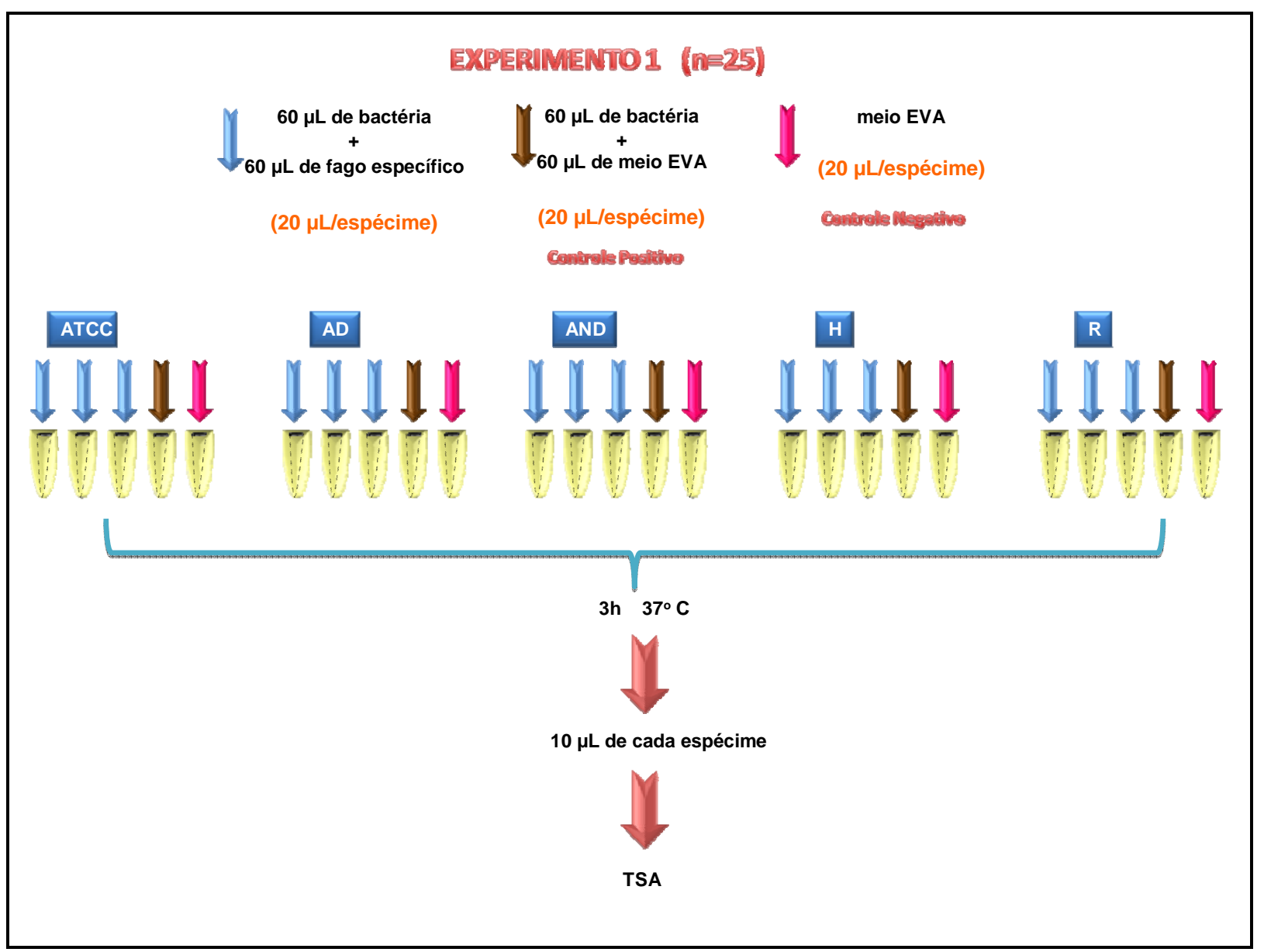

Figura 4.24 - Esquema ilustrativo do Experimento 1

\subsubsection{2 experimento 2}

Nove espécimes $(n=9)$ foram inoculados com $20 \mu \mathrm{L}$ da mistura das 5 cepas de Enterococcus faecalis e mantidos a $37{ }^{\circ} \mathrm{C}$ por 24 horas (Tabela 4.2). O décimo espécime $(n=1)$ recebeu somente EVA (controle negativo). Decorrido esse período, amostras foram colhidas para semeadura e todas as raízes foram inoculadas com 10 $\mu \mathrm{L}$ de EVA a cada 2 dias, durante 10 dias, com o propósito de manter condições apropriadas para a penetração das bactérias no interior dos túbulos dentinários. Os 
canais foram então secados com cones de papel absorvente esterilizados, sendo 8 deles inoculados com um preparado de fagos, composto por alíquotas iguais (100 $\mu \mathrm{L}$ ) de cada um dos lisados específicos, correspondentes às bactérias estudadas (ATCC, AD, AND, $\mathrm{H}$ e $\mathrm{R}$ ), e as demais apenas com EVA (controle positivo e negativo) (Tabela 4.3). Decorridas 24 horas de incubação a $37{ }^{\circ} \mathrm{C}$, foram feitas diluições seriadas e semeadura em placas contendo ágar TSA (Figura 4.24), a partir de alíquotas de $10 \mu \mathrm{L}$ obtidas de cada canal. Em seguida, todos os espécimes foram inoculados com EVA e novas diluições seriadas e semeadura realizadas após 48 horas e 10 dias de incubação a $37^{\circ} \mathrm{C}$. Durante o período de 10 dias, os espécimes continuaram recebendo meio de cultura a cada 2 dias, estimulando assim a reinfecção da luz do canal (Figura 4.25).

Outros 2 espécimes $(n=2)$ foram infectados do mesmo modo descrito acima com Enterococcus faecalis ATCC 29212 e processados para microscopia ótica e eletrônica de varredura.

Tabela 4.2 - Volumes dos inóculos usados nos espécimes do Experimento 2

\begin{tabular}{c|c|c|c}
\hline \multicolumn{2}{c|}{ Dentes } & $\begin{array}{c}9 \\
\text { espécimes }\end{array}$ & $\begin{array}{c}1 \text { espécimes } \\
\text { (controle negativo) }\end{array}$ \\
\hline \multirow{3}{*}{$\begin{array}{c}\text { Experimento } \\
2\end{array}$} & $\begin{array}{c}500 \mu \mathrm{L} \\
\text { de mistura das } \\
\text { bactérias }\end{array}$ & $20 \mu \mathrm{L}$ & ----- \\
\cline { 2 - 4 } & $\begin{array}{c}\text { Meio de cultura } \\
\text { EVA }\end{array}$ & ---- & $20 \mu \mathrm{L}$ \\
\hline
\end{tabular}


Tabela 4.3 - Volumes do preparado de fagos usados nos espécimes do Experimento 2

\begin{tabular}{c|c|c|c}
\hline \multicolumn{2}{c|}{ Dentes } & $\begin{array}{c}\mathbf{8} \\
\text { espécimes } \\
\text { (experimentais) }\end{array}$ & $\begin{array}{c}\mathbf{2} \\
\text { espécimes } \\
\text { (controles) }\end{array}$ \\
\hline \multirow{2}{*}{ Experimento 2 } & $\begin{array}{c}500 \mu \mathrm{L} \\
\text { do preparado de } \\
\text { fagos }\end{array}$ & $20 \mu \mathrm{L}$ & ---- \\
\cline { 2 - 4 } & $\begin{array}{c}\text { Meio de cultura } \\
\text { EVA }\end{array}$ & ---- & $20 \mu \mathrm{L}$ \\
\hline
\end{tabular}

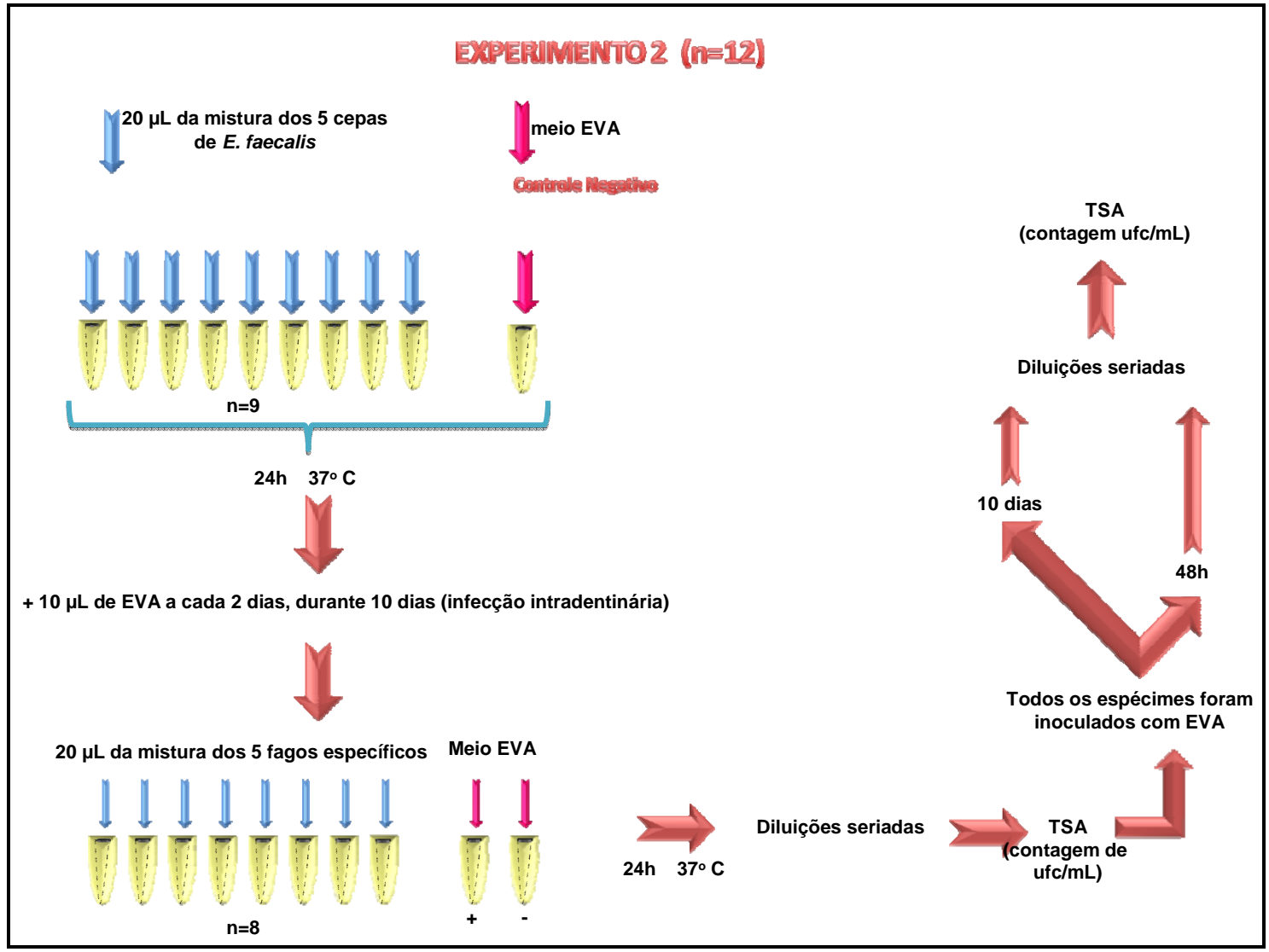

Figura 4.25 - Esquema ilustrativo do Experimento 2 
Foram realizadas três diferentes diluições para cada amostra coletada nos dois experimentos $\left(10^{-4}, 10^{-5}\right.$ e $\left.10^{-6}\right)$, e cada diluição foi semeada em triplicata em ágar TSA (Figura 4.26).

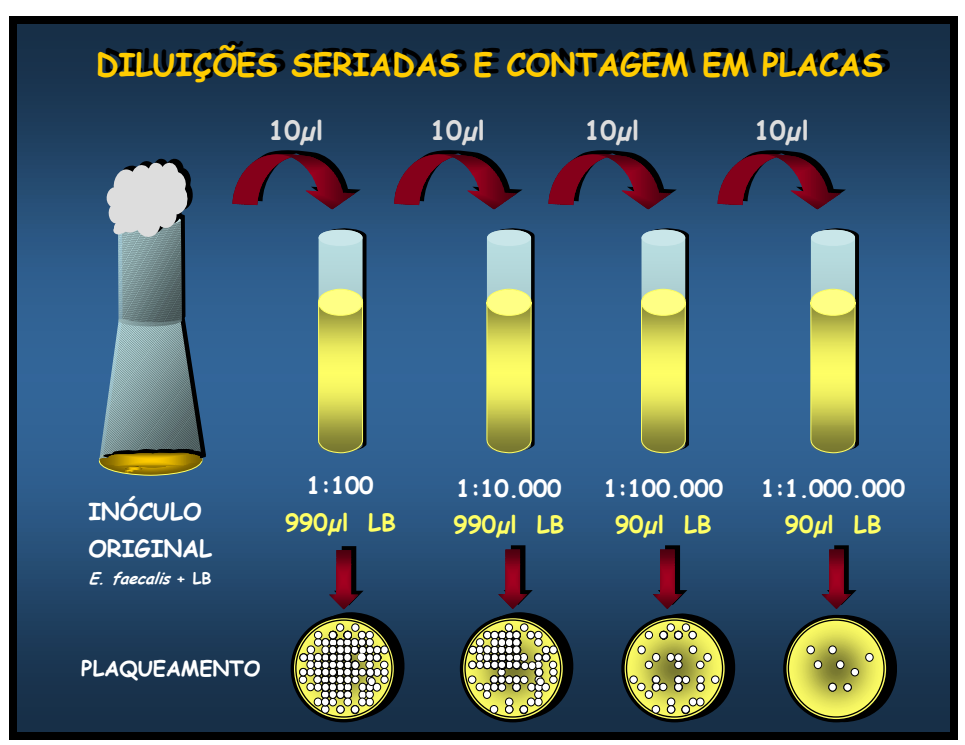

Figura 4.26 - Esquema ilustrativo das diluições seriadas e semeadura

4.2.7 Confirmação da infecção da dentina radicular humana com Enterococcus faecalis

4.2.7.1 cultura em meio sólido

No Experimento 2, uma alíquota de $5 \mu \mathrm{L}$ de cada um dos espécimes infectados com o inóculo bacteriano, foi semeada em uma placa contendo ágar TSA, 
antes da aplicação dos fagos, para confirmação da infecção após os 10 dias de incubação (Figura 4.27).

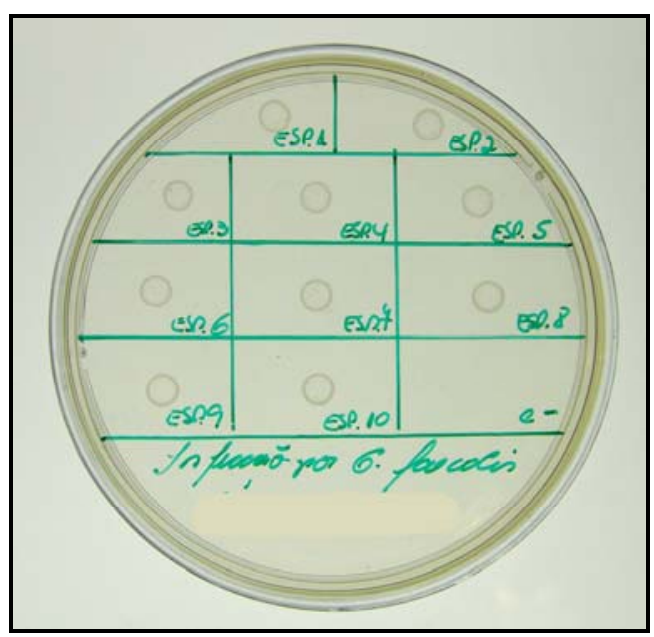

Figura 4.27 - Confirmação da infeç̧ão dos espécimes do Experimento 2, com inóculo de Enterococcus faecalis

\subsubsection{2 microscopia ótica}

Decorridos 10 dias de infecção, o espécime selecionado para observação dos túbulos dentinários com microscopia óptica, foi descalcificado em ácido fórmico a $60 \%$ e processado, utilizando-se corante a base de hematoxilina-eosina. As lâminas mostraram a penetração das bactérias em toda a extensão dos túbulos dentinários (Figura 4.28). 


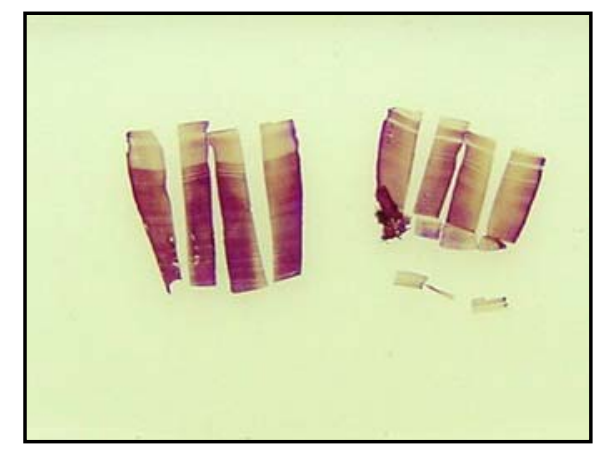

Figura 4.28 - Cortes histológicos da dentina radicular apresentando túbulos dentinários corados, indicando a presença de microrganismos

\subsubsection{3 microscopia eletrônica de varredura}

Um espécime infectado por 10 dias com Enterococcus faecalis ATCC 29212, foi devidamente processado para observação sob microscopia eletrônica de varredura, com o intuito de validar o protocolo de infecção dos túbulos dentinários adotado pelo estudo.

O espécime foi seccionado longitudinalmente e fixado em solução de glutaraldeído a 2,5 \% em tampão fosfato de sódio por 2 horas, em temperatura ambiente. Para removermos o glutaraldeído foi utilizada solução fisiológica contendo sacarose. A pós-fixação foi realizada por meio de solução de tetróxido de ósmio a 1\% em tampão fosfato de sódio. A seguir, as amostras foram desidratadas em etanol em série crescente, imersas em HMDS por 30 minutos e secadas no interior de uma capela de fluxo laminar. As amostras foram submetidas ao processo de sputtering sendo cobertas com uma camada de ouro de 120 nm. A microscopia eletrônica de varredura, para obtenção das fotomicrografias (Figura 4.29 a 4.32), foi realizada no microscópio Leo 430. 


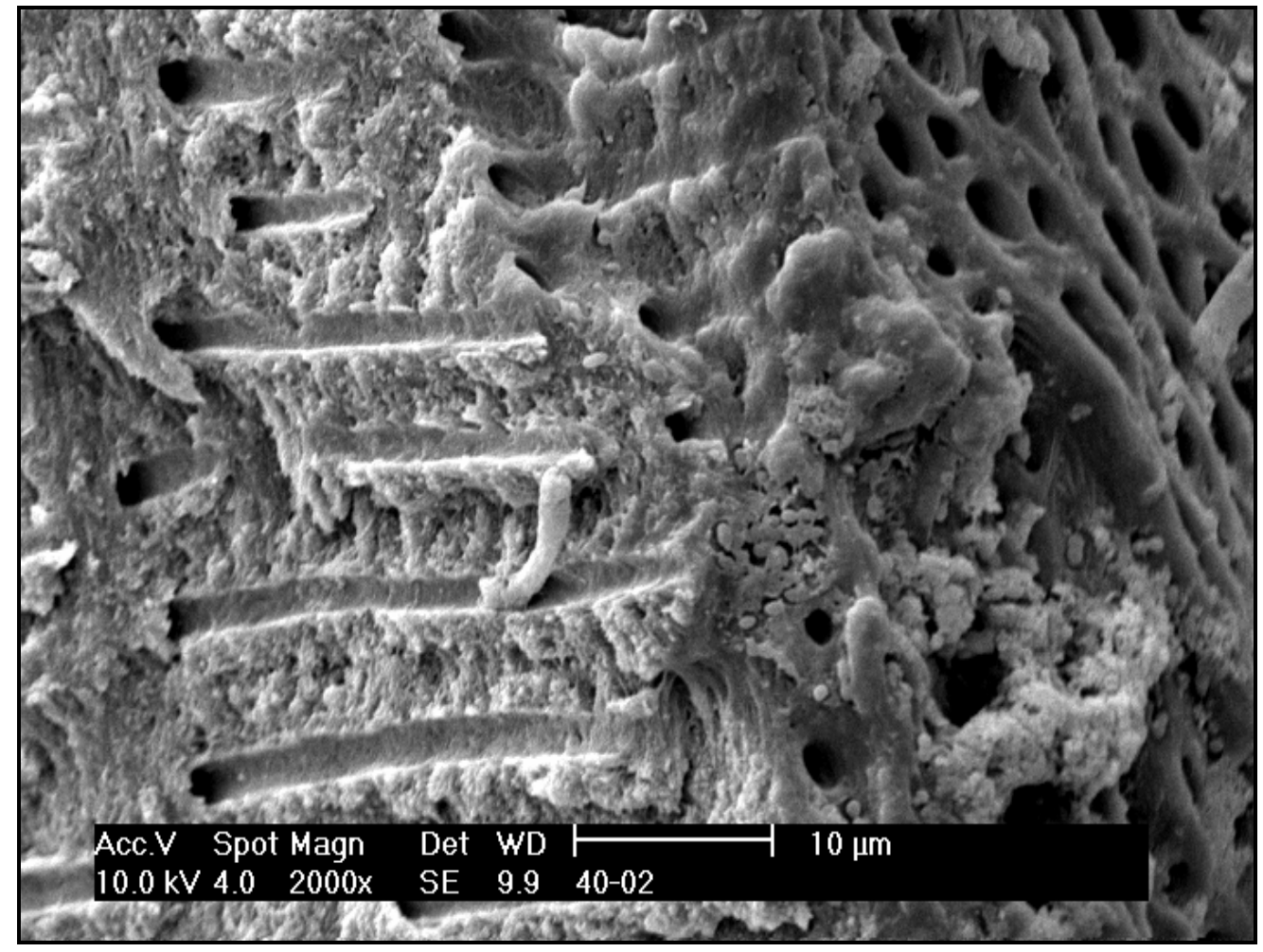

Figura 4.29 - Fotomicrografia mostrando os túbulos dentinários com ausência da smear-layer (aumento de 2000x)

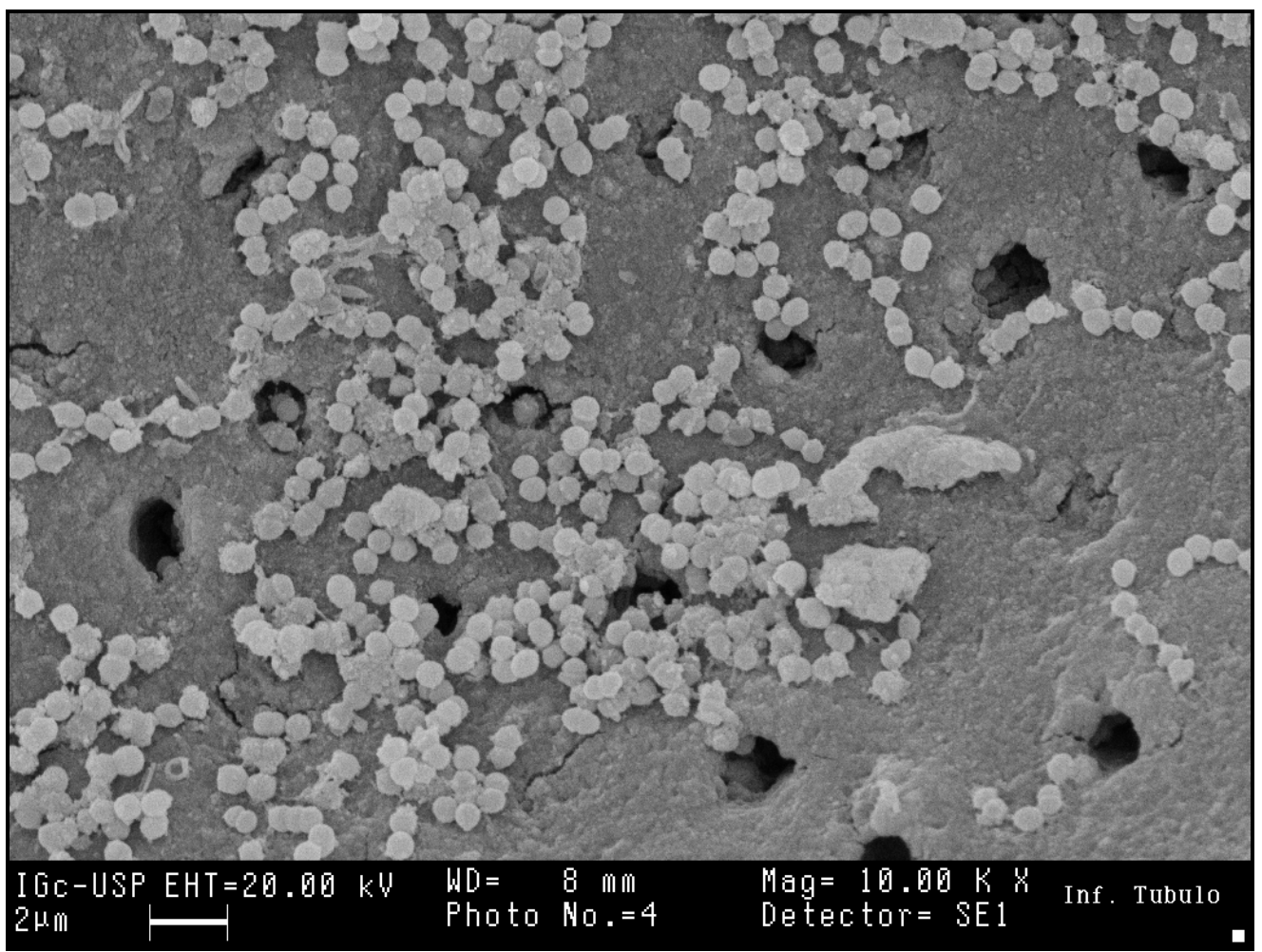

Figura 4.30 - Fotomicrografia apresentando dentina radicular humana infectada por Enterococcus faecalis (aumento de 10.000x) 


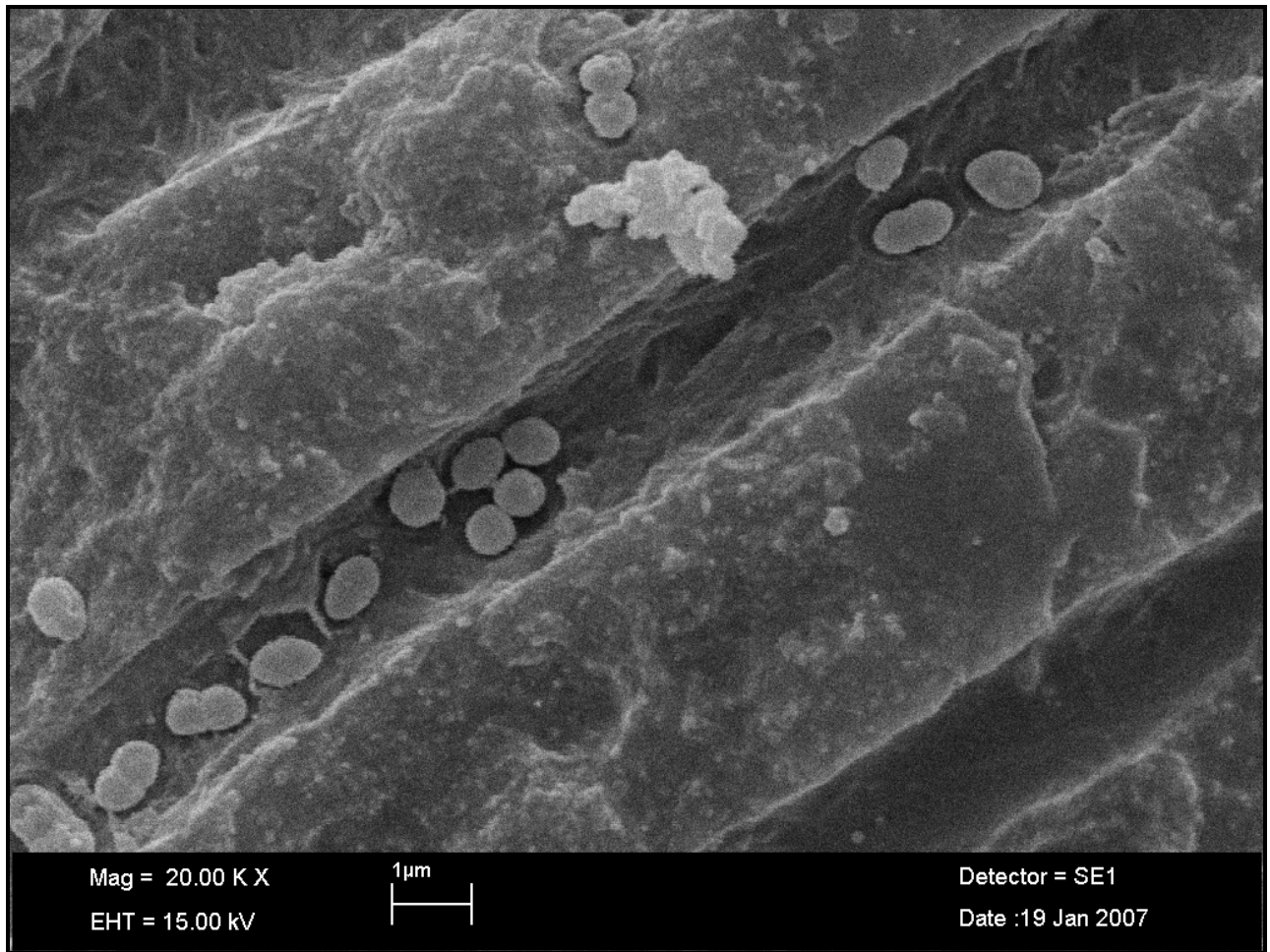

Figura 4.31 - Fotomicrografia apresentando infecção de túbulo dentinário humano infectado por Enterococcus faecalis (aumento de 20.000x)

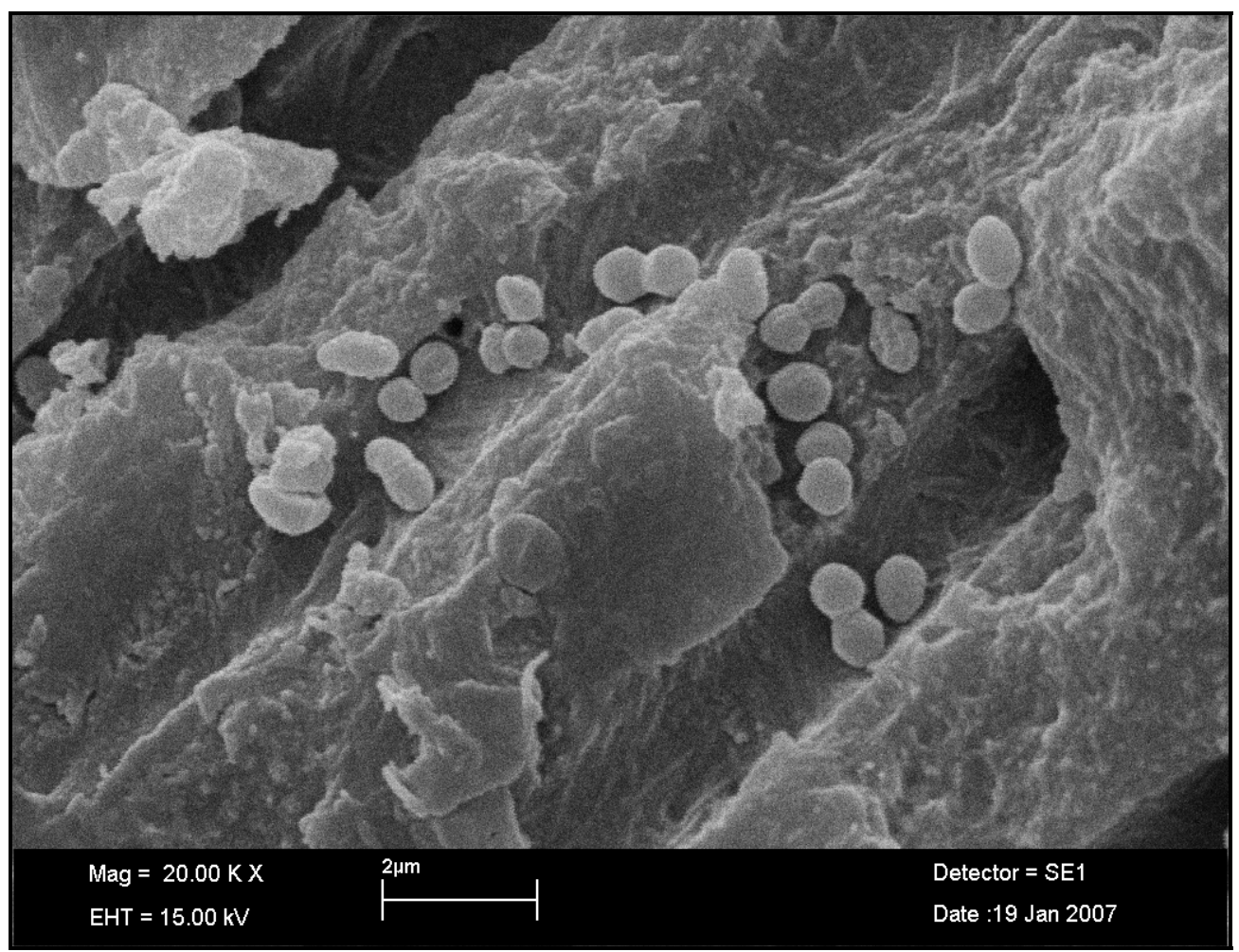

Figura 4.32 - Fotomicrografia apresentando túbulos dentinários de dentina radicular humana infectada por Enterococcus faecalis (aumento de 20.000x) 


\subsubsection{Pureza das culturas}

Nas placas onde ocorreu o crescimento do microrganismo, a pureza da cultura foi verificada através da análise das características morfotintoriais, pelo método de Gram. Os esfregaços de Enterococcus faecalis foram fixados pelo calor e cobertos com violeta de genciana e lavados em água destilada. Em seguida, esses esfregaços foram cobertos com lugol e então lavados com etanol. Na etapa final, foi feita a aplicação de fucsina, lavagem em água destilada e secagem (TORTORA; FUNKE; CASE, 2000). As características morfo-tintoriais foram observadas em microscópio ótico com aumento de 1.000 vezes (Figura 4.33).

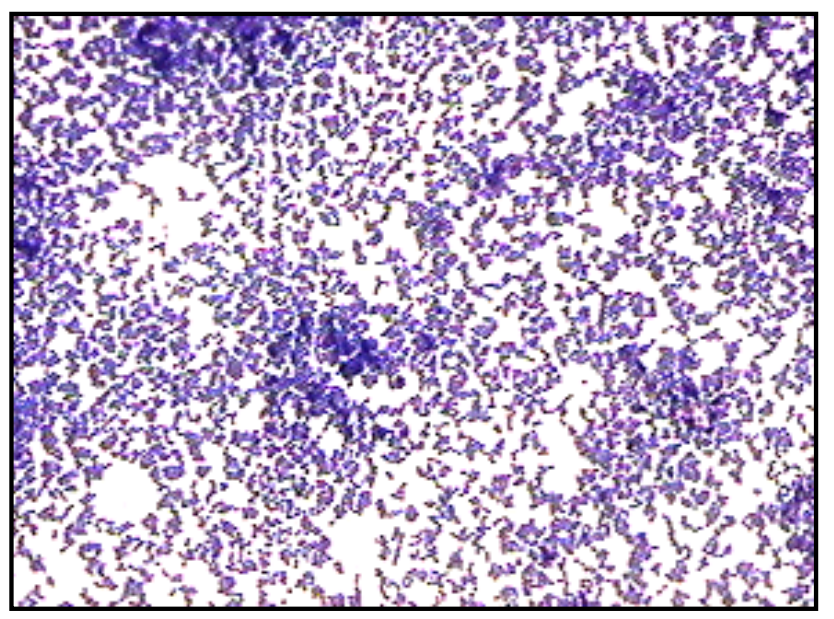

Figura 4.33 - Exemplo de esfregaço de Enterococcus faecalis corado pelo método de coloração de Gram, para confirmação da pureza das culturas (1000x) 


\subsubsection{Metodologia de avaliação}

A atividade antimicrobiana em dentina humana infectada por Enterococcus faecalis foi analisada comparando-se o número de unidades formadoras de colônias presentes nas semeaduras, obtidas dos espécimes que receberam a suspensão de fagos e dos respectivos controles positivos. Com esses valores, calculou-se a porcentagem de redução de crescimento bacteriano em cada espécime, nos dois experimentos (Figura 4.34).

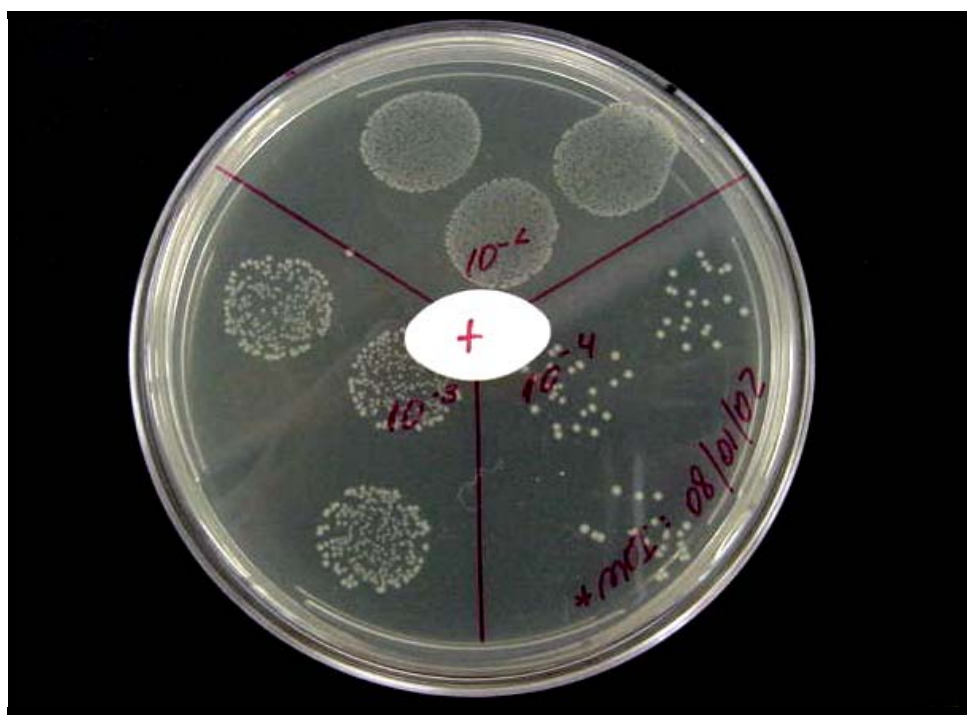

Figura 4.34 - Desenvolvimento do Enterococcus faecalis, em placa do tipo Petri contendo ágar TSA, a partir da semeadura de um controle positivo, para contagem das ufc 


\section{RESULTADOS}

Os resultados foram avaliados levando-se em consideração as diversas condições de infecção experimental, a eliminação de microrganismos do canal principal e dos túbulos dentinários, decorrendo a expressão disso nas tabelas e gráficos que seguem.

Tabela 5.1 - Crescimento bacteriano detectado nas semeaduras, obtidas dos canais radiculares de dentes humanos inoculados com Enterococcus faecalis, após aplicação da suspensão de fagos $(\mathrm{MOI}=1)$, por um período de três horas $(\mathrm{ufc} / \mathrm{mL})$

\begin{tabular}{c|cccccc}
\hline Espécimes & $\begin{array}{c}\text { Grupo I } \\
\text { (ATCC) }\end{array}$ & $\begin{array}{c}\text { Grupoll } \\
\text { (AD) }\end{array}$ & $\begin{array}{c}\text { Grupo III } \\
\text { (AND) }\end{array}$ & $\begin{array}{c}\text { Grupo IV } \\
\text { (H) }\end{array}$ & $\begin{array}{c}\text { Grupo V } \\
\text { (R) }\end{array}$ & $\begin{array}{c}\text { Grupo VI } \\
\text { (POL) }\end{array}$ \\
1 & 0 & 0 & 0 & 0 & 0 & 0 \\
2 & 0 & 0 & 0 & 0 & 0 & 0 \\
3 & 0 & 0 & 0 & 0 & 0 & 0 \\
4 & $2,0 \times 10^{8}$ & $1,75 \times 10^{8}$ & $1,9 \times 10^{8}$ & $2,8 \times 10^{8}$ & $2,3 \times 10^{8}$ & $2,0 \times 10^{8}$ \\
$\begin{array}{c}\text { (positivo) } \\
5\end{array}$ & 0 & 0 & 0 & 0 & 0 & 0 \\
$\begin{array}{c}\text { (negativo) } \\
\begin{array}{c}\text { Percentual } \\
\text { de redução } \\
\text { (\%) }\end{array}\end{array}$ & 100 & 100 & 100 & 100 & 100 & 100 \\
\hline
\end{tabular}




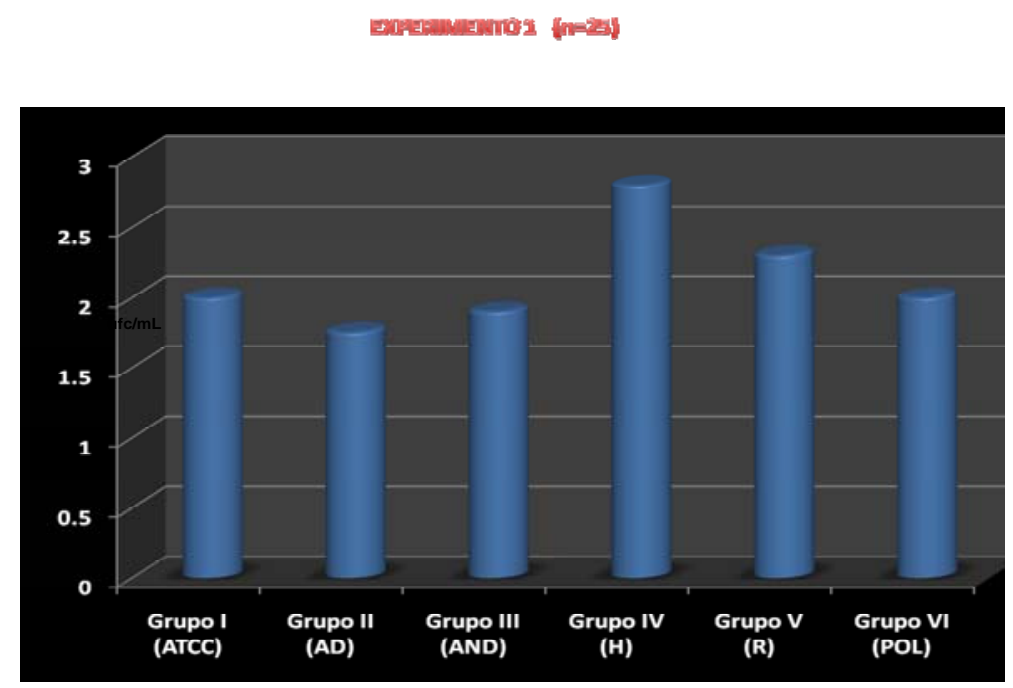

Gráfico 5.1 - Crescimento bacteriano obtido dos controles positivos nos grupos do experimento 1 após 3 horas da inoculação

Tabela 5.2 - Crescimento bacteriano detectado nas semeaduras obtidas dos canais radiculares de dentes humanos inoculados com 5 cepas de Enterococcus faecalis (10 dias), após aplicação da suspensão de fagos ou lisado híbrido, por um período de 24 horas (ufc/mL).

\begin{tabular}{|c|c|c|c|c|c|}
\hline DENTES & $\begin{array}{c}\text { INFECÇÃO } \\
\text { DENTINÁRIA } \\
10 \text { DIAS }\end{array}$ & $\begin{array}{c}1^{a} \text { COLETA } \\
\text { PÓS-FAGO } \\
24 \mathrm{~h} \\
\end{array}$ & $\begin{array}{c}2^{a} \text { COLETA } \\
\text { PÓS-FAGO } \\
48 h\end{array}$ & $\begin{array}{c}3^{a} \text { COLETA } \\
\text { PÓS-FAGO } \\
10 \text { DIAS }\end{array}$ & $\begin{array}{c}\% \text { DE } \\
\text { REDUÇÃO } \\
\text { FINAL }\end{array}$ \\
\hline 1 & $1,0 \times 10^{8}$ & $\begin{array}{c}1,86 \times 10^{6} \\
(98,1 \%)\end{array}$ & $\begin{array}{c}0 \\
(100 \%)\end{array}$ & $\begin{array}{c}0,55 \times 10^{8} \\
(50 \%)\end{array}$ & $50 \%$ \\
\hline 2 & $0,55 \times 10^{6}$ & $\begin{array}{c}0 \\
(100 \%)\end{array}$ & $\begin{array}{c}2,12 \times 10^{4} \\
(96,2 \%)\end{array}$ & $\begin{array}{c}0 \\
(100 \%)\end{array}$ & $100 \%$ \\
\hline 3 & $1,4 \times 10^{8}$ & $\begin{array}{c}1,7 \times 10^{6} \\
(98,8 \%)\end{array}$ & $\begin{array}{c}1,4 \times 10^{8} \\
(0 \%)\end{array}$ & $\begin{array}{c}0,8 \times 10^{8} \\
(42,9 \%)\end{array}$ & 42,9 \\
\hline 4 & $1,93 \times 10^{6}$ & $\begin{array}{c}0,4 \times 10^{4} \\
(99,8 \%)\end{array}$ & $\begin{array}{c}2,4 \times 10^{3} \\
(99,8 \%)\end{array}$ & $\begin{array}{c}0 \\
(100 \%)\end{array}$ & $100 \%$ \\
\hline 5 & $1,26 \times 10^{5}$ & $\begin{array}{c}0,13 \times 10^{4} \\
(99 \%)\end{array}$ & $\begin{array}{c}0 \\
(100 \%)\end{array}$ & $\begin{array}{c}0 \\
(100 \%)\end{array}$ & $100 \%$ \\
\hline 6 & $7,35 \times 10^{8}$ & $\begin{array}{c}0,13 \times 10^{4} \\
(99,9 \%)\end{array}$ & $\begin{array}{c}5,9 \times 10^{8} \\
(20 \%)\end{array}$ & $\begin{array}{c}1,32 \times 10^{8} \\
(82 \%)\end{array}$ & $82 \%$ \\
\hline 7 & $4,9 \times 10^{7}$ & $\begin{array}{c}1,4 \times 10^{5} \\
(99,7 \%)\end{array}$ & $\begin{array}{c}0 \\
(100 \%)\end{array}$ & $\begin{array}{c}2,4 \times 10^{7} \\
(51 \%)\end{array}$ & $51 \%$ \\
\hline 8 & $5,76 \times 10^{8}$ & $\begin{array}{c}6,2 \times 10^{5} \\
(99,9 \%)\end{array}$ & $\begin{array}{c}7,28 \times 10^{7} \\
(87,4 \%)\end{array}$ & $\begin{array}{c}0,88 \times 10^{8} \\
(84,7 \%)\end{array}$ & $84,7 \%$ \\
\hline $\begin{array}{c}9 \\
\text { POSITIVO* } \\
10\end{array}$ & $1,97 \times 10^{8}$ & $\frac{0,45 \times 10^{8}}{(77,1 \%)}$ & $\frac{0,77 \times 10^{8}}{(60,9 \%)}$ & $\frac{2,53 \times 10^{8}}{(28,4 \%)}$ & \\
\hline NEGATIVO* & & & & --------- & \\
\hline \multicolumn{4}{|c|}{ \% MÉDIA DE REDUÇÃO FINAL dos espécimes } & & $76,3 \%$ \\
\hline
\end{tabular}




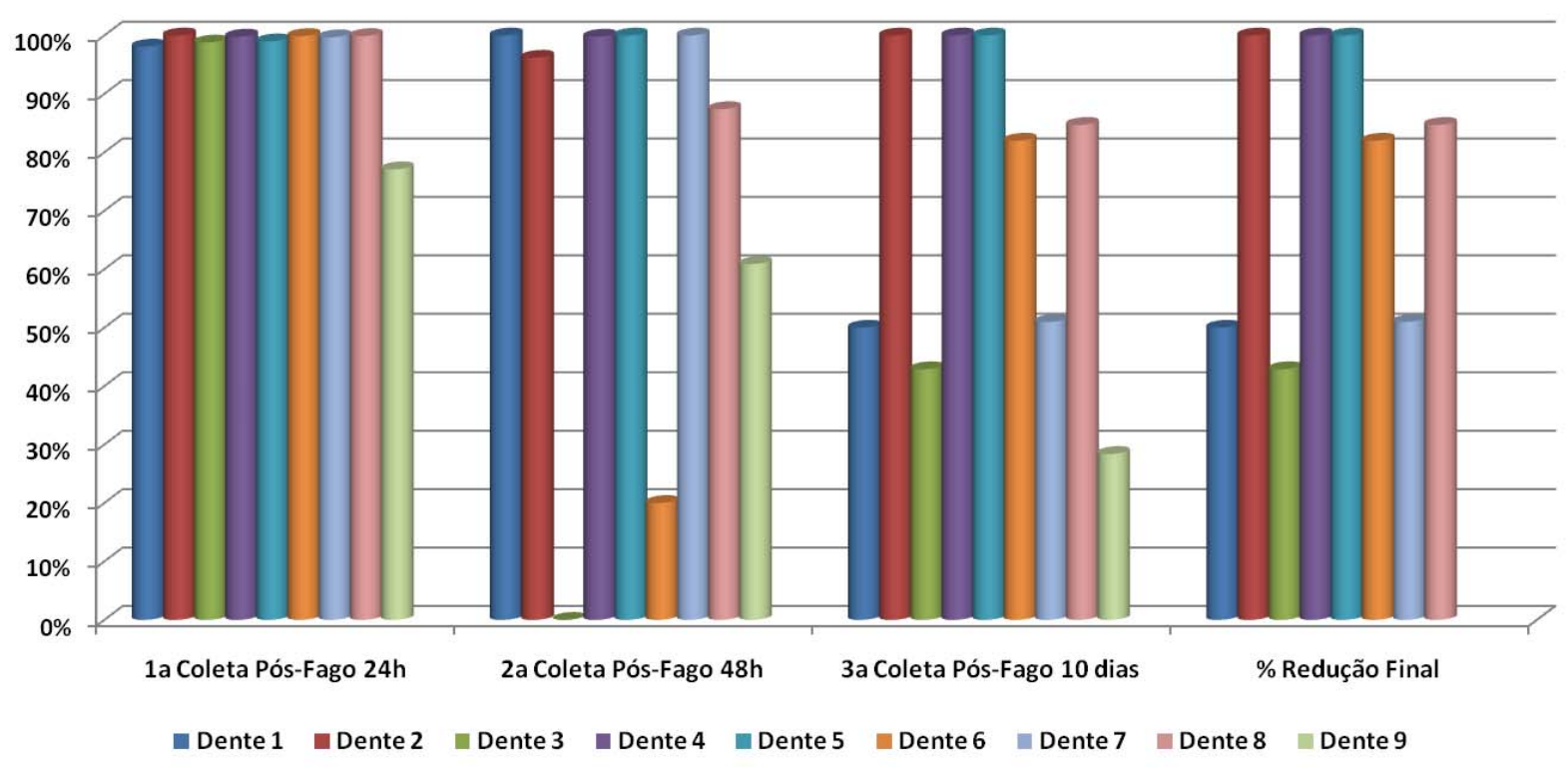

Gráfico 5.2 - Resultados da Tabela 5.2 (Experimento 2), comparando o crescimento bacteriano detectado nas semeaduras obtidas dos canais radiculares humanos inoculado com 5 cepas de Enterococcus faecalis (10 dias), após aplicação do lisado híbrido de fagos por um período de 24 horas (ufc/mL) 


\section{DISCUSSÃO}

A maioria dos problemas de origem endodôntica tem um agente etiológico bacteriano. Embora fungos e vírus já tenham sido isolados de canais radiculares infectados, bactérias são os microrganismos mais comumente associados à etiopatogenia das doenças pulpares e periapicais (LOPES; SIQUEIRA JR, 1999).

Fungos, embora em menor quantidade, também têm sido encontrados em casos de infecções primárias (FERRARI; CAI; BOMBANA, 2000; FERRARI; CAI; BOMBANA, 2001) e, principalmente em infecções secundárias (NAIR et al., 1990).

Desde o clássico estudo de Miller (1894) constatou-se que uma grande quantidade de bactérias viáveis se fazia presente em polpas necrosadas, mostrando que esses microrganismos estariam, de alguma forma, relacionados aos processos patológicos da polpa e do periodonto apical.

Até a década de 90, a quantidade de microrganismos reconhecidos na cavidade bucal, com potencial para infectar os canais radiculares, chegava à soma de 300 espécies (SUNDQVIST, 1992a). Atualmente, por meio de técnicas moleculares usadas na identificação de microrganismos, mais de 500 espécies já foram isoladas oriundas dessa região (PASTER et al., 2001). Contudo, desse total, apenas 200 espécies bacterianas diferentes, muitas potencialmente patogênicas, têm sido isoladas de canais infectados. A baixa tensão de oxigênio, o suplemento nutricional e o tipo de interação bacteriana (sinergismo ou antagonismo), determinam que apenas um grupo restrito componha a microbiota do canal infectado (SIQUEIRA JR, 1997; SUNDQVIST, 1992b). 
Com os avanços na área da Microbiologia após 1970, observou-se que a maior parte dos microrganismos que infectam os canais é anaeróbia estrita (FABRICIUS et al.,1982; LE GOFF et al., 1997; WITTGOW JR; SABISTON JR, 1975).

A polpa necrótica apresenta uma flora polimicrobiana caracterizada por associações entre 4 a 7 espécies por canal infectado, com predominância de anaeróbios, e proporções semelhantes de Gram-positivos e Gram-negativos (SUNDQVIST, 1992a,b).

No entanto, há diferenças significativas quanto à microbiota presente nas infecções endodônticas primárias, secundárias e persistentes.

Infecções persistentes, nas quais os canais passam por reintervenções ou tratamentos prolongados, o isolamento de anaeróbios facultativos é mais comum do que o de estritos (MOLANDER et al., 1998; SUNDQVIST et al., 1998).

Muitos estudos têm relatado que bactérias entéricas, em monoinfecção ou associadas a outras bactérias (infecções mistas), podem ser a causa de infecções persistentes ou secundárias (LOPES; SIQUEIRA JR, 1999).

Em relação a esse aspecto, saliente-se que Engström (1964) observou que em $14,9 \%$ das amostras coletadas de canais infectados havia presença de enterococos.

Outros estudos confirmaram que infecções persistentes são muitas vezes causadas por anaeróbios facultativos Gram-positivos, especialmente Enterococcus faecalis (HANCOCK III et al., 2001; MOLANDER et al., 1998; PECIULIENE et al., 2001; PINHEIRO et al., 2003a,b; SIRÉN et al., 1997; SUNDQVIST et al., 1998).

Inicialmente, aparece em pequenas proporções, porém quando se estabelece, é um microrganismo de difícil eliminação (DAHLÉN et al., 2000; 
ENGSTRÖM, 1964; FERRARI; CAI; BOMBANA, 2000; HAAPASALO; RANTA; RANTA, 1983; HEINTZ; DEBLINGER; OLIET, 1975).

Enterococcus faecalis são bactérias anaeróbias facultativas que, por serem menos exigentes quanto à presença de oxigênio e suplemento nutricional, são resistentes e permanecem por mais tempo no sistema de canais radiculares (FERRARI; CAI; BOMBANA, 2000; SUNDE et al., 2002; SUNDQVIST et al., 1998), conseguindo sobreviver até 10 dias no interior dos túbulos dentinários, sem nutrientes (ØRSTAVIK; HAAPASALO, 1990), mesmo na presença de medicação tópica a base de hidróxido de cálcio (HAAPASALO; ØRSTAVIK, 1987). Também são microrganismos predominantes em lesões periapicais fechadas, ou seja, sem comunicação com o meio bucal por cárie, doença periodontal ou fístula (ABOURASS; BOGEN, 1998), sendo capazes de formar biofilme no interior dos canais, o que, de certa forma, explica sua habilidade em sobreviver nesse ambiente, já que a camada de polissacarídeos os torna 1000 vezes mais resistentes aos quimioterápicos e aos anticorpos, quando comparados às formas planctônicas (DISTEL; HATTON; GILLESPIE, 2002).

Estudos mostram ainda, que essa bactéria está presente em infecções endodônticas associadas às lesões periapicais persistentes (ABOU-RASS, 1998; LANA et al., 2001; MOLANDER et al., 1998; NAIR et al., 1990; PECIULIENE et al., 2000; SUNDQVIST et al., 1998).

Além disso, recentes pesquisas têm mostrado que mecanismos bioquímicos são capazes de manter seu $\mathrm{pH}$ interno relativamente neutro, favorecendo seu crescimento tanto em ambientes ácidos como alcalinos (NAKAJO et al., 2006).

Devido a essas características, Enterococcus faecalis têm sido muito utilizados em estudos que avaliam a capacidade antimicrobiana de substâncias 
químicas auxiliares e de medicações de uso intracanal (AYHAN et al., 1999; BUCK et al., 2001; FERRAZ et al., 2001; GOMES et al., 2001; HAAPASALO et al., 2000; LIMA; FAVA; SIQUEIRA JR, 2001; ØRSTAVIK; HAAPASALO, 1990; SIQUEIRA JR; UZEDA, 1996; SIQUEIRA JR; UZEDA, 1997; SIQUEIRA JR et al., 2000).

Pinheiro et al. (2000), investigando dentes com insucesso no tratamento endodôntico, concluíram que a microbiota nesses casos, é formada, em sua maioria, por uma ou duas espécies representadas principalmente por anaeróbios facultativos Gram-positivos.

Estudos ainda mostram que Enterococcus faecalis quando colocado em contato com o hipoclorito de sódio, apresenta maior resistência que o Actinomyces, outro microrganismo presente em infecções persistentes (LOEFFLER; DJURKOVIC; FISCHETTI, 2003; RADCLIFFE et al., 2004).

Enterococcus faecalis foi a bactéria de escolha para o presente estudo, já que pertence ao grupo de bactérias mais resistentes aos procedimentos endodônticos convencionais (FERRARI; CAI; BOMBANA, 2005; NAKAJO et al., 2006; PINHEIRO et al., 2003a,b; RADCLIFFE et al., 2004; VIVACQUA-GOMES et al., 2005), e que, acorde Fabricius et al. (1982), não depende de associações com outras bactérias.

Além de enterococos, outras bactérias entéricas, como Enterobacter spp., Klebsiella spp., Pseudomonas spp. e Escherichia coli, podem estar envolvidas nas infecções endodônticas resistentes ao tratamento endodôntico, bem como Actinomyces spp., comumente presente na microbiota da cavidade bucal e trato respiratório em seres humanos (LOPES; SIQUEIRA JR, 1999; FERRARI; CAI; BOMBANA, 2001; TORTORA; FUNKE; CASE, 2000).

Os túbulos dentinários de dentes tratados endodonticamente ou com polpa necrosada favorecem a penetração de microrganismos na dentina (LOPES; 
SIQUEIRA JR, 1999). Por essa razão, diferentes modelos de estudo usando dentina radicular, vêm sendo pesquisados (AKPATA; BLECHMAN, 1982; HAAPASALO; ØRSTAVIK, 1987).

Essa invasão bacteriana da dentina deixa claro que culturas negativas obtidas apenas do canal principal não definem uma completa desinfecção (HAAPASALO; ØRSTAVIK, 1987).

Quanto à profundidade de infecção dos túbulos, as pesquisas mostram que a invasão bacteriana da dentina radicular parece aumentar proporcionalmente ao tempo de exposição, sugerindo que dentes portadores de polpas mortificadas, que passam por longos períodos de infecção, provavelmente necessitem de maior tempo de tratamento para a descontaminação (AKPATA; BLECHMAN, 1982).

Encontra-se na literatura, pesquisas nas quais o tempo de exposição da dentina aos microrganismos varia de três dias a seis semanas (ØRSTAVIK; HAAPASALO, 1990). Porém, Waltimo et al. (2000) observaram que houve penetração de Enterococcus faecalis em dentina humana, num período de um a cinco dias.

$\mathrm{Na}$ presente pesquisa adotou-se o período de 10 dias de infecção dos espécimes para que houvesse penetração do Enterococcus faecalis na extensão dos túbulos dentinários humanos, sendo esta situação comprovada histologicamente e microscopicamente (Figuras 4.28, 4.30, 4.31, 4.32).

A penetração de microrganismos na dentina também varia conforme a espécie bacteriana estudada, indicando que o tipo morfológico e arranjo celular influenciam esse comportamento (GEORGE; KISHEN; SONG, 2005; PEREZ et al., 1993; SIQUEIRA JR; UZEDA, 1996). No caso do Enterococcus faecalis, um 
estreptococos de origem fecal, a disposição em cadeia de suas células arredondadas facilitam sua penetração em profundidade nos túbulos dentinários.

Além do Enterococcus faecalis possuir a capacidade de sobreviver em meios onde oxigênio e suplemento nutricional são baixos, essa espécie é capaz de aderir ao colágeno presente nos túbulos dentinários, na presença de soro humano, dificultando sua eliminação principalmente quando atinge profundidades maiores na massa dentinária radicular (LOVE, 2001).

Embora fatores não-microbianos endógenos ou exógenos possam estar envolvidos em alguns casos de insucesso endodôntico, microrganismos e seus produtos, constituindo uma infecção persistente ou secundária, são os principais responsáveis pelo fracasso do tratamento endodôntico (MOLANDER et al., 1998; NAIR et al., 1990; SJÖGREN et al., 1997; SUNDQVIST et al., 1998).

A limpeza e a desinfecção do sistema de canais radiculares são feitas com a ação mecânica dos instrumentos, fluxo e refluxo de soluções irrigadoras e ação bactericida das soluções químicas auxiliares da instrumentação (LOPES; SIQUEIRA JR, 1999). Mesmo em casos de dentes associados à infecção de longa duração, os tratamentos endodônticos convencionais alcançam de $80 \%$ a $90 \%$ de sucesso.

Contudo, $10 \%$ a $20 \%$ resistem aos tratamentos antimicrobianos aplicados topicamente (BYSTRÖM; CLAESSON; SUNDQVIST, 1985; SAKAMOTO et al., 2007).

Muitas pesquisas têm abordado volumes, técnicas, concentrações e diferentes composições usadas para essa manobra (AYHAN et al., 1999; BERUTTI; MARINI; ANGERETTI, 1997; BUCK et al., 2001; D'ARCANGELO; VARVARA; FAZIO, 1999; FERRAZ et al., 2001; GOMES et al., 2001; SIQUEIRA JR et al., 1997; SIQUEIRA JR et al., 2000; YESILSOY et al., 1995). 
Soluções químicas como o hipoclorito de sódio e o digluconato de clorexidina, são substâncias de uso rotineiro na clínica endodôntica atual, e que devem ser usadas em concentrações mais altas principalmente quando o efeito antimicrobiano for necessário (OLIVEIRA et al., 2007; SENA et al., 2006; SPRATT et al., 2001).

A ação antimicrobiana do hipoclorito de sódio depende da maior concentração do ácido hipocloroso em solução, que possui capacidade de eliminar microrganismos por meio da oxidação de enzimas essenciais para o seu metabolismo (SIQUEIRA JR et al., 1997). Entretanto, o uso do hipoclorito de sódio em altas concentrações pode ser irritante aos tecidos periapicais, interferindo no processo de reparação (GOMES et al., 2001).

Oliveira et al. (2007) consideraram ao final de seu estudo, que o hipoclorito de sódio a $5,25 \%$ e o gel de clorexidina a $2 \%$, usados como substâncias químicas auxiliares da instrumentação, foram capazes de manter níveis baixos de Enterococcus faecalis após o preparo químico-cirúrgico, mesmo decorrido um período de sete dias.

O digluconato de clorexidina é um agente antimicrobiano de largo espectro, que apresenta substantividade, ou seja, ao se ligar à hidroxiapatita do esmalte ou da dentina será liberado lentamente, prolongando assim sua ação antimicrobiana. Ele age penetrando na parede celular e causando danos à membrana citoplasmática da bactéria, levando ao extravasamento do seu conteúdo. Em altas concentrações, provoca coagulação dos componentes intracelulares, destruindo rapidamente os microrganismos (LOPES; SIQUEIRA JR, 1999). Devido a tais propriedades, o uso da clorexidina na terapia endodôntica tem sido preconizado tanto como medicação intracanal, como na irrigação de canais radiculares infectados. 
A pesquisa realizada por Menezes et al. (2004), mostrou ainda que a clorexidina 2\% usada como solução irrigadora, eliminou mais Enterococcus faecalis do que o hipoclorito de sódio a $2,5 \%$, em canais infectados in vitro.

Além do aumento da concentração, as propriedades antimicrobianas do hipoclorito de sódio e da solução de clorexidina são melhoradas quando usados sob agitação mecânica, principalmente nos casos de infecções de longa duração, onde encontramos microrganismos na forma de biofilme (SENA et al., 2006).

Shabahang e Torabinejad (2003) estudaram o efeito antimicrobiano de uma nova substância irrigadora, o MTAD, composta por um isômero de tetraciclina (doxiciclina), ácido cítrico e detergente (TWEEN 80), na eliminação in vitro de Enterococcus faecalis. Apesar do Enterococcus faecalis ser resistente à tetraciclina por via sistêmica, ele foi eliminado após a instrumentação na presença de hipoclorito de sódio a $1,3 \%$ e aplicação do MTAD por cinco minutos, como irrigação final. Outras pesquisas mostram que o efeito antimicrobiano do MTAD foi inferior, quando comparado ao uso do hipoclorito de sódio em altas concentrações (JOHAL; BAUMGARTNER; MARSHALL, 2007), principalmente quando testado na presença de pó de dentina e Bovine Serum Albumin (BSA) (PORTENIER et al., 2006). Essa influência do pó de dentina e do BSA na ação antimicrobiana de substâncias químicas usadas na desinfecção dos canais radiculares, deve ser sempre levada em consideração ao se avaliar os resultados obtidos em testes in vivo e in vitro (HAAPASALO et al., 2000).

Para que as soluções químicas atuem em profundidade na dentina, se faz necessária a eliminação do magma dentinário, resultante do preparo dos canais. A efetividade dos irrigantes depende da sua capacidade de penetração nos túbulos, processo influenciado claramente pela presença ou ausência do magma (BERUTTI; 
MARINI; ANGERETTI, 1997). As associações de soluções quelantes, como o EDTA, e detergentes que diminuem sua tensão superficial, mostram bom desempenho na eliminação dessa estrutura amorfa (PAIVA; ANTONIAZZI, 1993). Por essa razão, durante o preparo do espécime, fez-se o uso de EDTA-T a 17\%, para que houvesse aumento no padrão de permeabilidade dentinária.

Além da dificuldade no acesso aos microrganismos sediados no interior dos túbulos, os quais não são eliminados rotineiramente durante a desinfecção do canal radicular (BUCK et al., 2001), os mesmos também permanecem protegidos da ação de agentes antimicrobianos administrados sistemicamente (OGUNTEBI, 1994). Conseqüentemente, quando o objetivo principal do tratamento endodôntico for a desinfecção do sistema de canais radiculares, medicações de uso intracanal ou métodos tópicos efetivos devem ser aplicados (HAAPASALO; ØRSTAVIK, 1987; OGUNTEBI, 1994; SHOVELTON, 1964; TROPE; DELANO; ØRSTAVIK, 1999).

Pelo fato de permanecerem por tempo mais prolongado no interior do canal radicular, as medicações tópicas têm maiores chances de atingir áreas não afetadas pela instrumentação e pela substância química auxiliar, exercendo assim sua ação antibacteriana e contribuindo decisivamente para a máxima redução da microbiota endodôntica (SIQUEIRA JR, 1997; TROPE; DELANO; ØRSTAVIK, 1999).

A medicação intracanal ideal deveria apresentar a capacidade de neutralizar os microrganismos e seus componentes patogênicos (proteínas, enzimas e toxinas), e de induzir uma resposta do hospedeiro que favoreça a reparação. Entretanto, a ocorrência de culturas positivas após a limpeza e modelagem de canais infectados, mesmo após a aplicação de substâncias antimicrobianas, justifica novas investigações. 
O paramonoclorofenol (PMC), introduzido na Odontologia por Walkhoff em 1891, é um derivado do fenol que atua inclusive por meio da liberação de vapores. As combinações do PMC com outras substâncias ou sua diluição têm sido usadas com o propósito de potencializar sua atividade antimicrobiana e reduzir sua citotoxicidade (LOPES; SIQUEIRA JR,1999). A associação do PMC com a cânfora (PMCC) propicia um aumento do poder germicida, reduzindo também seu potencial de irritação (LEONARDO; LEAL, 1991).

Ainda nos dias de hoje, novas associações vêm sendo propostas com o intuito de minimizar o efeito citotóxico e manter a efetividade antimicrobiana do PMC. Lage-Marques e Antoniazzi (2000) propuseram a associação do PMC ao polietilenoglicol 400 e Rinossoro, denominando essa associação de fármacos de PRP.

Como a maioria das bactérias patogênicas ao homem não é capaz de sobreviver em meio extremamente alcalino, medicações a base de hidróxido de cálcio, que apresentam $\mathrm{opH}$ em torno de 12,5 , têm sido muito estudadas e aplicadas na prática endodôntica (LEONARDO; LEAL, 1991; LOPES; SIQUEIRA JR, 1999).

O hidróxido de cálcio altera as propriedades biológicas dos lipopolissacarídeos da parede celular das bactérias Gram-negativas, o que inativa mecanismos de transporte da membrana, provocando citotoxicidade (LEONARDO; LEAL, 1991). Além disso, seu efeito antimicrobiano à distância, no interior dos túbulos dentinários, se deve a sua habilidade em absorver o dióxido de carbono $\left(\mathrm{CO}_{2}\right)$ usado para o crescimento microbiano (KONTAKIOTIS; WU; WESSELINK, 1997) e também a sua capacidade de liberar íons hidroxila, que penetram através da massa dentinária (WAKABAYASHI et al., 1995). 
Pesquisas como a de Byström, Claesson e Sundqvist (1985) confirmaram que o hidróxido de cálcio realmente exerce efeito letal sobre as células bacterianas. No entanto, muitos desses trabalhos mostram a atividade dessa substância em contato direto com as bactérias, onde a concentração de íons hidroxila, responsáveis pela ação bactericida do composto, atinge níveis incompatíveis com sua sobrevivência (LOPES; SIQUEIRA JR, 1999).

Estudos demonstraram que o hidróxido de cálcio não é tão eficaz na eliminação dos microrganismos presentes no interior dos túbulos dentinários (HAAPASALO; ØRSTAVIK, 1987; ØRSTAVIK; HAAPASALO, 1990; SAFAVI; SPÅNGBERG; LANGELAND, 1990). Siqueira Jr e Uzeda (1996), trabalhando com infecção intratubular em dentina bovina, demonstraram que o hidróxido de cálcio associado à solução salina não foi eficaz na eliminação de Enterococcus faecalis (bactéria anaeróbia facultativa) e Fusobacterium nucleatum (bactéria anaeróbia estrita), mesmo após uma semana de contato. Contudo, nesse mesmo trabalho, os autores observaram que a pasta de hidróxido de cálcio associada ao PMCC foi eficaz na desinfecção dos túbulos dentinários infectados experimentalmente com essas bactérias anaeróbias, em um período máximo de 24 horas.

A pasta de hidróxido de cálcio veiculada em PMCC, também apresentou melhor efeito antimicrobiano em relação ao Enterococcus faecalis e a Candida albicans, quando comparada ao PMCC, PMCC furacinado, tricresol formalina e a pasta de hidróxido de cálcio em solução fisiológica (MENEZES et al., 2004).

De acordo com várias pesquisas (BYSTRÖM; CLAESSON; SUNDQVIST, 1985; DAHLÉN et al., 2000; HAAPASALO; ØRSTAVIK,1987) o hidróxido de cálcio pode não ser a melhor escolha quando há presença de enterococos e leveduras, já que estes microrganismos apresentam tolerância a meios alcalinos. Em casos de 
reintervenções, microrganismos que sobrevivem na presença do hidróxido de cálcio são freqüentemente isolados, sugerindo a aplicação de medicações alternativas para sua eliminação (MOLANDER et al., 1998).

A clorexidina tem sido aplicada como medicação intracanal em várias concentrações (ØRSTAVIK; HAAPASALO, 1990; YESILSOY et al., 1995). Guimarães, Cai e Lage-Marques (2001) testaram o efeito da clorexidina a $2 \%$ e do paramonoclorofenol a $2 \%$, em veículo gel, diante do Enterococcus faecalis. Os resultados apontaram a clorexidina como importante agente antimicrobiano, principalmente nos casos de reintervenções ou processos infecciosos persistentes. Contudo, essa pesquisa foi feita em dentina bovina, onde a presença de túbulos dentinários de maior diâmetro em comparação à dentina humana, facilita a atuação das substâncias antimicrobianas.

O estudo de Lima, Fava e Siqueira Jr (2001) comparou o efeito antimicrobiano do gluconato de clorexidina e de medicações contendo antibióticos, em biofilmes formados por Enterococcus faecalis. Apesar da associação da clindamicina com o metronidazol reduzir significativamente o número de células bacterianas, as medicações que continham o gel de digluconato de clorexidina a $2 \%$, apresentaram melhor desempenho em relação à eliminação de microrganismos organizados em biofilme.

A idéia da associação do hidróxido de cálcio com a solução de digluconato de clorexidina era esperada, já que ambos apresentam excelentes propriedades antimicrobianas. Contudo, ainda não há um consenso entre as investigações realizadas in vitro com essa associação. Embora alguns estudos mostrem uma significante melhora na atividade antimicrobiana do hidróxido de cálcio veiculado em solução de clorexidina (SIQUEIRA JR; PAIVA; RÔÇAS, 2007; ZERELLA; FOUAD; 
SPÁNGBERG, 2005), outros não recomendam essa associação, na medida em que os melhores resultados foram alcançados quando somente o hidróxido de cálcio foi empregado (LYNNE et al., 2003).

Apesar da clorexidina precipitar em pH básico e perder parte de sua atividade, ela mantém o meio alcalino e a atividade antimicrobiana do hidróxido de cálcio, oferecendo resultados clínicos que não devem ser ignorados (ZERELLA; FOUAD; SPÁNGBERG, 2005).

A simples presença da dentina parece ter um efeito inibitório da capacidade antimicrobiana de algumas substâncias, dentre elas o hidróxido de cálcio (HAAPASALO et al., 2000).

Portanto, as substâncias desinfetantes devem possuir a capacidade de penetrar nos túbulos dentinários, manter sua concentração inibitória e resistir à inativação provocada pela presença da dentina. Mesmo a presença física dos microganismos diminuiu o efeito bactericida das substâncias utilizadas durante a terapia endodôntica (PORTENIER et al., 2002). Além disso, segundo Portenier et al. (2005), os diferentes estágios do crescimento microbiano parecem influenciar o comportamento das substâncias químicas. As cepas de Enterococcus faecalis se mostraram muito mais resistentes ao hidróxido de cálcio, à clorexidina e ao hipoclorito de sódio, na fase de declínio, e suscetíveis a esses agentes na fase log ou fase de crescimento bacteriano.

O presente estudo utilizou dentina humana infectada por Enterococcus faecalis, para se conseguir maior proximidade com a realidade clínica, na qual essa bactéria dificilmente é eliminada do interior dos túbulos dentinários.

Os microrganismos mais resistentes à terapia endodôntica podem ser denominados superinfectantes ou oportunistas, sendo assim chamados por serem 
altamente resistentes a múltiplos antibióticos (WITTGOW JR; SABISTON JR, 1975). Espécies de enterococos, especialmente Enterococcus faecalis, fazem parte desse grupo (DAHLÉN et al., 2000; SIRÉN et al., 1997; SUNDQVIST et al., 1998).

Atualmente, com o problema crescente da resistência bacteriana aos quimioterápicos, terapias alternativas que utilizam diferentes mecanismos na eliminação de microrganismos, vêm sendo pesquisadas. Exemplo disso são estudos que utilizam o laser na desinfecção dos canais radiculares (BLUM; MICHAILESCO; ABADIE, 1997; BONVECHIO et al., 2000; MEHL et al., 1999).

Os microrganismos resistentes foram selecionados à medida que a prescrição de antibióticos passou a ser indiscriminada pelos próprios profissionais da área da saúde. Os antibióticos podem ser bactericidas, quando eliminam as bactérias, ou bacteriostáticos, quando interferem no metabolismo bacteriano, impedindo ou desacelerando o seu crescimento. Os microrganismos tornam-se resistentes quando modificam alguns de seus componentes celulares após a exposição a determinado antibiótico, prevenindo-se da absorção de tal droga ou inativando suas moléculas. A partir daí, eles continuarão crescendo, multiplicando-se, liberando toxinas e perpetuando assim a infecção (TORTORA; FUNKE; CASE, 2000).

Lana et al. (2001) investigando a ação antimicrobiana da eritromicina frente aos gêneros Veillonella, Peptostreptococcus e Fusobacterium, confirmaram sua baixa atividade na inibição do crescimento de bactérias anaeróbias presentes em infecções endodônticas. Nesse mesmo estudo, a resistência apresentada pelos anaeróbios facultativos ao metronidazol, alerta para escolha de uma terapia antimicrobiana específica, minimizando o aumento da resistência entre os microrganismos. 
Já, a pesquisa feita por Pinheiro et al. (2003b), na qual a resistência aos antibióticos oferecida pelas bactérias presentes em canais obturados foi avaliada, mostrou que $20 \%$ das cepas de Enterococcus faecalis foram resistentes à eritromicina e $60 \%$ à azitromicina, restringindo por esse aspecto o uso dessa alternativa de antibioticoterapia nos casos de pacientes alérgicos às penicilinas.

Os bacteriófagos ou fagos são vírus que infectam e crescem no interior da bactéria, e por não possuírem metabolismo próprio, dependem inteiramente de hospedeiros suscetíveis para se multiplicarem (NISENGARD; NEWMAN, 1997).

Esses vírus foram descobertos em 1915 pelo microbiologista britânico Felix Twort e, independentemente, em 1917, pelo microbiologista franco canadense Felix d'Hérelle. Essa descoberta logo despertou o interesse no desenvolvimento de uma terapia que pudesse combater os processos infecciosos, já que na época os antibióticos não eram conhecidos e a cura das infecções dependia exclusivamente da reação imunológica do hospedeiro (CARLTON, 1999; GOYAL; GERBA; BITTON, 1987; TORTORA; FUNKE; CASE, 2000).

A terapia bacteriofágica ou fagoterapia continuou se desenvolvendo como meio de prevenção e cura de infecções até a década de 1940, quando surgiram os primeiros antibióticos. A nova droga agia de maneira mais do que satisfatória no combate às doenças. Com o estabelecimento da terapia por antibióticos as pesquisas com bacteriófagos, usados como agentes terapêuticos, foram praticamente abandonadas (GOYAL; GERBA; BITTON, 1987).

Desde então, os fagos se tornaram um importante instrumento no desenvolvimento de áreas como a Virologia, Biologia Molecular e Genética, esclarecendo, entre outros fatores, o mecanismo de replicação do ácido nucléico, a recombinação genética e a estrutura do gene (GOYAL; GERBA; BITTON, 1987). 
A fagotipagem é um teste feito para determinar à quais fagos uma bactéria é suscetível, já que esses vírus são altamente especializados, infectando somente membros de uma espécie bacteriana em particular, ou até mesmo linhagens particulares de uma espécie. Cada vez menos utilizada, a fagotipagem foi sendo substituída por métodos que utilizam o DNA bacteriano na identificação de células procariotas (TORTORA; FUNKE; CASE, 2000).

Apesar de centros de pesquisa nos Estados Unidos, França e países que compunham a extinta União das Repúblicas Socialistas Soviéticas continuarem os estudos sobre fagoterapia (CARLTON, 1999), somente na década de 80 ela foi redescoberta, despertando novamente o interesse da comunidade científica mundial (BARROW; SOOTHILL, 1997).

Os bacteriófagos são constituídos de material genético (DNA ou RNA) encapsulado por capa protéica (capsídeo). Além disso, alguns fagos apresentam uma cauda também protéica, através da qual a partícula fágica se liga à superfície da célula hospedeira, sendo este o passo inicial para a infecção (NISENGARD; NEWMAN, 1997).

A principal vantagem do uso dos bacteriófagos em comparação aos quimioterápicos está na sua grande capacidade de replicação. Como qualquer outro vírus, cada célula infectada libera uma grande quantidade de novos vírus capacitados para infectar outras bactérias (BARROW; SOOTHILL, 1997; CARLTON, 1999; MERRIL et al., 1996). Essa característica sugere que uma única dose de fagos pode ser suficiente no combate a uma infecção. Além disso, o uso da fagoterapia proporciona redução no aparecimento de novas cepas resistentes aos antibióticos e, dado o seu mecanismo de ação, elimina somente cepas bacterianas 
específicas, não ocorrendo alterações na flora presente (BARROW; SOOTHILL, 1997; MERRIL et al., 1996; SMITH; HUGGINS, 1982).

Por outro lado, essa mesma característica é desvantajosa, já que a maioria dos fagos não atua em casos de infecção mista (BARROW; SOOTHILL, 1997; CARLTON, 1999).

Contudo, técnicas de engenharia genética podem modificar as características dos fagos, tornando-os mais efetivos ou polivalentes (BARROW; SOOTHILL, 1997; CARLTON, 1999).

Os fagos podem se multiplicar por dois mecanismos alternativos: o ciclo lítico ou o ciclo lisogênico. O ciclo lítico termina com a lise e a morte da célula hospedeira, enquanto que no ciclo lisogênico a célula permanece viva (TORTORA; FUNKE; CASE, 2000).

Portanto, as chances de se obter sucesso no emprego da fagoterapia, aumentam quando se utiliza suspensões de fagos líticos, ou também chamados de fagos virulentos.

Pesquisas com fagoterapia in vivo despertam muito interesse, especialmente por descreverem casos em que todo tipo de terapia antibiótica já foi utilizado sem sucesso.

Smith e Huggins (1982) estudaram a ação de um fago lítico para cepa de Escherichia coli, em ratos brancos inoculados com dose letal dessa bactéria, por via intramuscular e intracerebral. A notada superioridade da aplicação de uma única dose desse fago, em relação ao uso de múltiplas doses de tetraciclina, ampicilina, cloranfenicol e trimetoprima com sulfafurazole, comprovou a capacidade dos fagos de se perpetuarem enquanto houver presença de microrganismos suscetíveis, característica das mais desejáveis em se tratando de agentes antimicrobianos. 
Estudos mostram que, após o uso da fagoterapia, há o surgimento de bactérias resistentes a alguns fagos, mas que apresentam virulência muito menor em comparação a das cepas iniciais (SMITH; HUGGINS, 1982; SMITH; HUGGINS, 1983).

A prevenção da doença causada por Escherichia coli em bezerros também foi conseguida quando uma suspensão aquosa de fagos foi esborrifada nos cercados ocupados anteriormente por animais doentes (PEREPANOVA et al., 1995; SMITH; HUGGINS; SHAW, 1987a). Isso sugere que suspensões aquosas de fagos podem ser usadas topicamente.

Infecções sistêmicas, cutâneas e mucosas podem ser tratadas em adultos, crianças, pacientes imunossuprimidos e portadores de câncer, sendo os fagos administrados por via oral, parenteral ou tópica. Os efeitos colaterais dos fagos são muito raros e reversíveis. Sintomas gastrointestinais e alérgicos ocorreram em menos de $1 \%$ dos pacientes, conforme Slopek et al. (1984) e Cislo et al. (1987).

Em 1958, Meyers, Walter e Green publicaram um dos primeiros estudos sobre o isolamento de fagos líticos para Lactobacillus, a partir da cavidade oral, sugerindo sua participação nessa microbiota. Hiroki et al. (1976) chegaram a isolar um total de 25 diferentes fagos para Veillonella, a partir da cavidade bucal e placa dental. Outros trabalhos, que evidenciaram a presença de fagos na cavidade oral, saliva, cárie, placa dental e sulco gengival, sugerem o possível uso da fagoterapia na Odontologia (BACHRACH et al.,2003; BRADY; GRAY; CALDWELL, 1977; GREER et al., 1971; HALHOUL; COLVIN, 1975; TYLENDA et al., 1985).

A investigação conduzida por Bachrach et al. (2003) isolou fagos para Enterococcus faecalis a partir da saliva humana, confirmando sua presença mesmo após um ano da coleta inicial. Isso mostra que esses fagos participam da microbiota 
oral normal e que seu uso na prevenção de insucessos endodônticos parece ser plausível.

Os bacteriófagos apresentam ainda dimensões bem menores quando comparados às bactérias (TORTORA; FUNKE; CASE, 2000), facilitando sua penetração nos túbulos dentinários, no caso de infecções endodônticas.

Porém, na maior parte das infecções do sistema de canais radiculares, as bactérias estão presentes em forma de biofilme, protegidas da ação dos antimicrobianos, quimioterápicos e defesas do próprio hospedeiro (LOPES; SIQUEIRA JR, 1999; LIMA; FAVA; SIQUEIRA JR, 2001). No entanto, os fagos conseguem eliminar essas bactérias albergadas nesse material formado por lipopolissacarídeos, valendo-se de enzimas específicas que desorganizam esse micro ecossistema (HANLON et al., 2001; HITCH; PRATTEN; TAYLOR, 2004).

O uso da fagoterapia implica na identificação das bactérias envolvidas na infecção, já que os fagos são altamente específicos (GOYAL; GERBA; BITTON, 1987; TORTORA; FUNKE; CASE, 2000). A solução para essa desvantagem, seria a aplicação de preparados polivalentes, formados por diferentes fagos, que possam eliminar uma maior variedade de gêneros e espécies microbianas (DZULIASHVILI et al., 2007), sobretudo em infecções mistas.

O uso de uma medicação viva, a base de vírus, seria uma outra preocupação no caso do uso da fagoterapia em seres humanos. No entanto, em revisão da literatura publicada por Dabrowska et al. (2005), os autores analisaram os mecanismos biológicos da ação dos fagos e, embasados em trabalhos científicos, afirmaram que estes não são capazes de interagir com células eucarióticas, a menos que sejam modificados geneticamente. Contudo, mesmo quando ocorre essa interação, nunca foi observada a replicação viral no interior dessas células. Os 
autores ainda sugerem o uso da fagoterapia, já que os animais e seres humanos são expostos aos fagos durante toda a vida, principalmente nos casos de infecções provocadas por microrganismos resistentes aos antibióticos, e lembram que as vacinas, usadas em grande escala atualmente, também carregam microrganismos vivos em sua composição (INAL, 2003).

Portanto, casos de infecção endodôntica que não respondem aos tratamentos convencionais poderiam usar uma suspensão de fagos como medicação tópica intracanal ou como substância irrigadora. Por essa razão, nesta investigação foi proposto avaliar o comportamento de cepas de Enterococcus faecalis diante da aplicação de uma suspensão de fagos líticos específicos para esse microrganismo.

O presente estudo analisou o efeito antimicrobiano de uma suspensão composta por fagos específicos para Enterococcus faecalis, quando presentes na luz do canal radicular e no interior dos túbulos dentinários, em dentes humanos.

Para este estudo, foram isolados fagos específicos para cinco diferentes cepas de Enterococcus faecalis, uma delas proveniente de laboratório de cepas padrão (ATCC 29212), e quatro outras obtidas a partir de isolados clínicos.

A caracterização macroscópica dos fagos isolados mostrou semelhança entre as placas de lise de cada um dos lisados, sendo todas elas pequenas, transparentes e com bordas regulares. A análise da ultra-estrutura, por MET, revelou que todos os fagos pertenciam à ordem Caudovirales (REGENMORTEL et al., 2000) e família Siphoviridae, sendo o fago correspondente a cepa de Enterococcus faecalis ATCC 29212, de morfotipo San21 e os demais, H-19J, segundo a classificação de Ackermann et al. (1997) (ANEXO M). 
Todos os fagos da família Siphoviridae apresentam cauda longa não contrátil e DNA de dupla fita (REGENMORTEL et al. 2000), esta última característica confirmada através da digestão de seu material genômico por enzimas de restrição.

Devido à multiplicação exponencial do fago, titulações mais baixas em relação ao número de bactérias podem ser suficientes na eliminação das bactérias alvo (GOYAL; GERBA; BITTON, 1987; PAISANO et al., 2004). Contudo, especialmente na fagoterapia, são utilizadas altas concentrações de fagos para um melhor efeito antimicrobiano.

Nos experimentos realizados, a titulação $10^{8} \mathrm{ufp} / \mathrm{mL}$ foi utilizada, na tentativa de se aplicar um número de fagos proporcional ao número de bactérias presentes, após a infecção dos espécimes $\left(1,7 \times 10^{8} \mathrm{ufc} / \mathrm{mL}\right)$.

O primeiro experimento confirmou os achados de Paisano et al. (2004), mostrando que houve uma redução de $100 \%$ no crescimento bacteriano restrito à luz do canal, em todos os grupos experimentais (Tabela 4.1). Isso mostra que o ambiente oferecido pelo interior do canal radicular, não interferiu na ação bactericida da suspensão de fagos, diferente de alguns agentes antimicrobianos usados na terapia endodôntica, como o hipoclorito de sódio, a clorexidina, o hidróxido de cálcio e o MTAD, que apresentam essa capacidade reduzida em contato com a dentina e seus componentes (HAAPASALO et al., 2000; PORTENIER et al., 2006).

Contudo, a preocupação atual nos casos de canais infectados é a eliminação das bactérias do interior dos túbulos dentinários, principalmente nos casos em que o tratamento endodôntico convencional não obteve sucesso.

Isso sugere que espécies bacterianas resistentes, que sobrevivem ao preparo químico-cirúrgico e até a aplicação de variadas formas de medicação intracanal, requerem métodos alternativos para sua eliminação. 
No segundo experimento desta investigação, os espécimes foram inoculados com uma mistura das 5 cepas estudadas, por 10 dias, favorecendo assim a infecção dos túbulos dentinários. Segundo Waltimo et al. (2000), o Enterococcus faecalis é capaz de penetrar na massa dentinária rapidamente (1 a 5 dias), devido ao tamanho das células envolvidas. Decorrido o período de infecção, um preparado dos diferentes fagos isolados ou lisado híbrido polivalente foi aplicado por um período de 24 horas e novas amostras colhidas. Houve uma significativa redução do crescimento bacteriano, mesmo 48 horas e 10 dias após a retirada da suspensão de fagos e preenchimento dos canais com meio de cultura. Essa manobra favoreceria a reinfecção da luz do canal (ØRSTAVIK; HAAPASALO, 1990) e, conseqüentemente, o crescimento bacteriano nas semeaduras, o que ocorreu significativamente menos em comparação aos controles positivos (Tabela 5.2).

É importante ressaltar, que os canais foram expostos por 10 dias aos enterococos, tempo suficiente para a formação de biofilme bacteriano (SENA et al., 2006). Hanlon et al. (2001) estudaram a ação lítica de fagos específicos diante de biofilmes de Pseudomonas aeruginosa, demonstrando que apesar de não apresentarem motilidade, os fagos conseguiram alcançar as bactérias albergadas na massa polissacarídica, reduzindo sua viscosidade por meio da ação de enzimas produzidas no interior das próprias bactérias hospedeiras, estimuladas quando expostas aos lisados específicos.

A proposta deste estudo foi avaliar o efeito antimicrobiano somente dos fagos, não sendo utilizadas manobras de instrumentação, irrigação com substâncias químicas, ou qualquer tipo de medicação intracanal, agitação mecânica ou ultrasônica (que segundo Sena et al. (2006), aumenta a ação dos agentes antimicrobianos), procedimentos esses, que poderiam desorganizar o biofilme 
bacteriano, bem como eliminar os microrganismos, mecânica ou quimicamente. Outro fator que contribuiu para o crescimento bacteriano foi o preenchimento dos canais, no segundo experimento, com meio de cultura após a aplicação dos fagos, manobra que estimula demasiadamente sua reinfecção.

Diante disso, conclui-se que apesar dos resultados mostrarem significativa redução no crescimento bacteriano posterior à aplicação dos fagos, manobras rotineiras, como a instrumentação dos canais e a aplicação de medicação tópica, seriam complementadas positivamente pela fagoterapia.

Quanto à sua eliminação do interior dos canais, os fagos são neutralizados na presença de formaldeído ou hipoclorito de sódio (SMITH; HUGGINS; SHAW, 1987b), substâncias comuns do arsenal endodôntico.

O desenvolvimento de uma coleção de fagos isolados ou suspensões híbridas correspondentes aos microrganismos responsáveis por infecções resistentes aos quimioterápicos, representa uma importante alternativa para a cura desses processos. Para isso, técnicas como o congelamento em baixas temperaturas e a liofilização são usados para a estocagem e manutenção da viabilidade dos fagos. No primeiro procedimento as suspensões são congeladas rapidamente em temperaturas que variam de $-50{ }^{\circ} \mathrm{C}$ a $-95^{\circ} \mathrm{C}$, permanecendo viáveis por vários anos. Durante a liofilização a suspensão a base de fagos é rapidamente congelada nas temperaturas entre $-54{ }^{\circ} \mathrm{C}$ e $-72{ }^{\circ} \mathrm{C}$, ocorrendo em seguida, a remoção total da água através da utilização de alto vácuo (sublimação). Ao final do processo, ampolas ou frascos contendo o pó residual são selados utilizando uma chama de alta temperatura, para que também possam ser estocados durante anos e usados ao acrescentar-se um veículo próprio (TORTORA; FUNKE; CASE, 2000; ZIERDT, 1959; ZIERDT, 1988). Com base em técnicas como a liofilização, os fagos podem 
também ser administrados em forma de comprimidos via oral, o que facilita sua comercialização, bem como o controle quanto à concentração utilizada.

Para que a fagoterapia se torne uma das alternativas nos casos de reintervenções ou processos infecciosos refratários, outras pesquisas in vitro, quanto ao seu espectro de ação, farmacodinâmica (uso de veículos que melhorem seu desempenho) e citotoxicidade, são necessárias, já que há uma grande variedade no padrão morfológico e comportamental desses vírus.

Em comparação ao uso de quimioterápicos, os fagos apresentam vantagens como serem administrados em dose única, não eliminar a flora comensal e dificilmente causar efeitos colaterais após sua administração (BOGOVAZOVA; VOROSHILOVA; BONDARENKO, 1991). Além do baixo custo envolvido em sua produção, novas suspensões podem ser produzidas rapidamente quando surgirem cepas resistentes (CARLTON, 1999; INAL, 2003).

Diante do exposto, a fagoterapia parece promissora, não só na Endodontia, com a irrigação e medicação dos canais, mas também em outras áreas da Odontologia, onde suspensões a base de fagos podem ser usadas como colutórios ou mesmo durante os procedimentos cirúrgicos, na prevenção de infecções (LAZAREVA et al., 2001).

Barrow (2001) relatou que a fagoterapia deve ser considerada principalmente nos casos de infecções em que há presença de bactérias resistentes, como Staphylococcus aureus, Staphylococcus epidermidis, Enterococcus faecium e Enterococcus faecalis.

Os fagos poderão ser usados, no futuro, isoladamente na eliminação de bactérias resistentes aos antibióticos, ou associados à antibioticoterapia, em casos nos quais há presença de bactérias ainda suscetíveis às drogas (CARLTON, 1999). 
Metodologias científicas modernas que utilizam a engenharia genética e a biologia molecular tornam promissor o uso dos bacteriófagos no combate às infecções (LOEFFLER; DJURKOVIC; FISCHETTI, 2003), porém enquanto houver antibióticos disponíveis e bactérias suscetíveis, os fagos provavelmente não serão a terapia de primeira escolha. Contudo, o irreversível e preocupante aumento da resistência bacteriana aos quimioterápicos abriu um novo caminho à fagoterapia, principalmente em casos onde já se esgotaram as alternativas para controle de sinais e sintomas característicos dos processos infecciosos refratários. 


\section{CONCLUSÕES}

A análise dos resultados obtidos no presente estudo permite concluir que:

1. as cinco suspensões de fagos específicos apresentaram efeito antimicrobiano contra as cepas de Enterococcus faecalis correspondentes, no interior de canais radiculares humanos.

2. a suspensão composta pelos cinco fagos ou lisado híbrido polivalente mostrou capacidade antimicrobiana tanto na luz do canal radicular como no interior dos túbulos dentinários, reduzindo significativamente o crescimento bacteriano (50\% a 100\%) nos espécimes infectados por 10 dias com as diferentas cepas de Enterococcus faecalis estudadas. 


\section{REFERÊNCIAS ${ }^{1}$}

Abou-Rass M, Bogen G. Microorganisms in closed periapical lesions. Int Endod J 1998;31(1):39-47.

Ackermann HW, Dubow MS, Gershman M, Karska-Wysocki B, Kasatiya SS, Loessner MJ, et al. Taxonomic changes in tailed phages of enterobacteria. Arch Virol 1997;142(7):1381-90.

Akpata ES, Blechman $\mathrm{H}$. Bacterial invasion of pulp dentin wall in vitro. J Dent Res 1982;61(2):435-8.

Ayhan H, Sultan N, Cirak M, Ruhi MZ, Bodur H. Antimicrobial effects of various endodontic irrigants on selected microorganisms. Int Endod J 1999;32(2):99-102.

Bachrach G, Leizerovici-Zigmond M, Zlotkin A, Naor R, Steinberg D. Bacteriophage isolation from human saliva. Lett Appl Microbiol 2003;36(1):50-3.

Barrow PA.The use of bacteriophages for treatment and prevention of bacterial disease in animals and animal models of human infection. J Chem Technol Biotechnol 2001;76(7):677-82.

Barrow PA, Soothill JS. Bacteriophage therapy and prophylaxis : rediscovery and renewed assessment of potential. Trends Microbiol 1997;5(7):268-71.

Berchieri JR, Lovell M, Barrow PA. The activity in the chicken alimentary tract of bacteriophages lytic for Salmonella typhimurium. Res Microbiol 1991;142(5):541-9.

Berutti E, Marini R, Angeretti A. Penetration ability of different irrigants into dentinal tubules. J Endod 1997;23(12):725-7.

Blum J, Michailesco P, Abadie MJM. An evaluation of the bactericidal effect of the Nd: YAD laser. J Endod 1997;23(9):583-5.

\footnotetext{
${ }^{1}$ De acordo com Estilo Vancouver. Abreviatura de periódicos segundo base de dados MEDLINE.
} 
Bogovazova GG, Voroshilova NN, Bondarenko VM. The efficacy of Klebsiella pneumoniae bacteriophage in the therapy of experimental Klebsiella infeccion.Zh Mikrobiol Epidemiol Immunobiol 1991;(4):5-8.

Bonvechio PF, Canettieri ACV, Gomes APM, Mello GPS, Jorge AOC. Avaliação do laser Nd: YAG na desinfecção de canais radiculares contaminados com Candida albicans. Pesqui Odontol Bras 2000;14:59. Suplemento [Resumo SBPqO I380 ].

Brady JM, Gray WA, Caldwell MA. The electron microscopy of bacteriophage-like particles in dental plaque. J Dent Res 1977;56(8):991-3.

Brenner S, Horne RW. A negative staining method for high resolution electron microscopy of viruses. Biochim Biophys Acta 1959;34:103-10.

Buck RA, Eleazer PD, Staat RH, Scheetz JP. Effectiveness of three endodontic irrigants at various tubular depths in human dentin. J Endod 2001;27(3):206-8.

Byström A, Claesson R, Sundqvist G. The antibacterial effect of camphorated paramonochlorophenol, camphorated phenol and calcium hydroxide in the treatment of infected root canals. Endod Dent Traumatol 1985;1(5):170-5.

Carlton RM. Phages therapy: past history and future prospects. Arch Immunol Ther Exp 1999;47(5):267-74.

Cislo M, Dabrowski M, Weber-Dabrowska B, Woytoń A. Bacteriophage treatment of suppurative skin infections. Arch Immunol Ther Exp 1987;35(2):175-83.

Dabrowska K, Switala-Jelen K, Opolski A, Weber-Dabrowska B, Gorski A. Bacteriophage penetration in vertebrates. J Appl Microbiol 2005;98(1):7-13.

Dahlén G, Samuelsson W, Molander A, Reit C. Identification and antimicrobial susceptibility of enterococci isolated from the root canal. Oral Microbiol Immunol 2000;15(5):309-12.

D'Arcangelo C, Varvara G, Fazio P. An evaluation of the action of different root canal irrigants on facultative aerobic-anaerobic, obligate anaerobic, and microaerophilic bacteria. J Endod 1999;25(5):351-3. 
Distel JW, Hatton JF, Gillespie MJ. Biofilm formation in medicated root canals. J Endod 2002;28(10):689-93.

Dzuliashvili M, Gabitashvili K, Golidjashvili A, Hoyle N, Gachechiladze K. Study of therapeutic potencial of the experimental pseudomonas bacteriophage preparation. Georgian Med News 2007;(147):81-8.

Engström B. The significance of enterococci in root canal treatment. Odontol Revy 1964;15(2):87-106.

Ercan E, Dalli M, Dülgergil T, Yaman F. Effect of intracanal medication with calcium hydroxide and $1 \%$ chlorhexidine in endodontic retreatment cases with periapical lesions: an in vivo study. J Formos Med Assoc 2007;106(3):217-24.

Fabricius L, Dahlén G, Ohman AE, Möller AJ. Predominant indigenous oral bacteria isolated from infected root canals after varied times of closure. Scand J Dent Res 1982;90(2):134-44.

Ferrari HP, Cai S, Bombana AC. Detecção de microorganismos superinfectantes em canais radiculares de pacientes portadores de necrose pulpar com câmaras pulpares fechadas [Resumo SBPqO B342 ]. Pesqui Odontol Bras 2000;14:150. Suplemento.

Ferrari HP, Cai S, Bombana AC. Detecção de microorganismos superinfectantes em pacientes portadores de infecção endodôntica de caráter primário [Resumo SBPqO A048 ]. Pesqui Odontol Bras 2001;15(76). Suplemento.

Ferrari HP, Cai S, Bombana AC. Effect of endodontic procedures on enterococci, enteric bacteria and yeasts in primary endodontic infections. Int Endod J $2005,38(6): 372-80$.

Ferraz CCR, Gomes BP, Zaia AA, Teixeira FB, Souza-Filho FJ. In vitro assessment of the antimicrobial action and the mechanical ability of chlorhexidine gel as an endodontic irrigant. J Endod 2001;27(7): 452-5.

George S, Kishen A, Song KP. The role of environmental changes on monospecies biofilm formation on root canal wall by Enterococcus faecalis. J Endod 2005;31(12):867-72. 
Gomes BPFA, Ferraz CC, Carvalho KC, Souza-Filho FJ, Rosalen PL. Variações na suscetibilidade de alguns microrganismos aos medicamentos intracanais [Res. B053]. In: $16^{a}$ Reunião Anual da Sociedade Brasileira de Pesquisa Odontológica; 1999 set 8-11; Águas de São Pedro. São Paulo: SBPqO; 1999. p. 21.

Gomes BPFA, Ferraz CC, Vianna ME, Berber VB, Teixeira FB, Souza-Filho FJ. In vitro antimicrobial activity of several concentrations of sodium hypoclorite and chlorhexidine gluconate in the elimination of Enterococcus faecalis. Int Endod J 2001;34(6):424-8.

Goyal SM, Gerba CP, Bitton G. Phage Ecology. New York: Wiley-Interscience; 1987.

Greer SB, Hsiang W, Musil G, Zinner DD. Viruses of cariogenic streptococci. J Dent Res 1971;50(6):1594-604.

Guimarães CCP, Cai S, Lage-Marques J L. Atividade antimicrobiana da clorexedina e do paramonoclorofenol, em veículo gel. Pesqui Odontol Bras 2001:15(73).

Suplemento [Resumo SBPqO A024].

Haapasalo MPP, Ranta H, Ranta KT. Facultative gram-negative enteric rods in persistent periapical infections. Acta Odontol Scand 1983;419(1):19-22.

Haapasalo MPP, Ørstavik D. In vitro infection and disinfection of dentinal tubules. J Dent Res 1987;66(8):1375-9.

Haapasalo HK, Sirén EK, Waltimo TM, Ørstavik D, Haapasalo MP. Inactivation of local root canal medicaments by dentine: an in vitro study. Int Endod J 2000;33(2):126-31.

Halhoul N, Colvin JR. Virus-like particles in association with a microorganism from human gingival plaque. Arch Oral Biol 1975;20(12):833-6.

Hancock III HH, Sigurdsson A, Trope M, Moiseiwitsch J. Bacteria isolated after unsuccesful endodontic treatment in a North American population. Oral Surg Oral Med Oral Pathol 2001;91(5):579-86.

Hanlon GW, Denyer SP, Olliff CJ, Ibrahim LJ. Reduction in exopolysaccharide viscosity as an aid to bacteriophage penetration through Pseudomonas aeruginosa biofilms. Appl Environ Microbiol 2001;67(6):2746-53. 
Heintz CE, Deblinger R, Oliet S. Antibiotic sensitivities of enterococci isolated from treated root canals. J Endod 1975;1(11):373-6.

Hiroki H, Shiiki J, Handa A, Totsuka M, Nakamura O. Isolation of bacteriophages specific for the genus Veillonella. Arch Oral Biol 1976;21(3):215-6.

Hitch G, Pratten J, Taylor PW. Isolation of bacteriophages from the oral cavity. Lett Appl Microbiol 2004;39(2):215-9.

Inal J. Phage therapy: a reappraisal of bacteriophages as antibiotics. Arch Immunol Ther Exp 2003;51(4):237-44.

Johal S, Baumgartner JC, Marshall JG. Comparison of the antimicrobial efficacy of $1,3 \% \mathrm{NaOCl} / \mathrm{BioP}$ ure MTDA to $5,25 \% \mathrm{NaOCl} / 15 \%$ EDTA for root canal irrigation. $\mathrm{J}$ Endod 2007;33(1):48-51.

Kakehashi S, Stanley HR, Fitzgerald RJ. The effects of surgical exposures of dental pulps in germ-free and conventional laboratory rats. Oral Surg Oral Med Oral Pathol 1965;20(3):340-9.

Kalfas S, Fidgor D, Sundqvist G. A new bacterial species associated with failed endodontic treatment: identification and discription of Actinomyces radicidentis. Oral Surg Oral Med Oral Pathol 2001;92(2):208-14.

Kontakiotis EG, Wu MK, Wesselink PR. Effect of calcium hydroxide dressing on seal of permanent root filling. Endod Dent Traumatol 1997;13(6):281-4.

Kwarcinski W, Lazarkiewicz B, Weber-Dabrowska B, Rudnicki J, Kamiński K, Sciebura M. Bacteriophage therapy in the treatment of recurrent subphrenic and subhepatic abscess with jejunal fistula after stomach resection. Pol Tyg Lek 1994;49(23-24):535.

Lage-Marques JL, Antoniazzi JH. Quando a medicação intracanal é fundamental para o sucesso da terapia endodôntica. In: Feller C.; Gorab R. Atualização na clínica odontológica. São Paulo: Artes Médicas 2000; p.59-89.

Lana MA, Ribeiro-Sobrinho AP, Stheling R, Garcia GD, Silva BKC, Hamdan S, et al. Microorganisms isolated from root canals presenting necrotic pulp and their drugs susceptibility in vitro. Oral Microbiol Immunol 2001;16(2):100-5. 
Lazavera EB, Smirnov SV, Khvatov VB, Spiridonova TG, Bitkova EE, Darbeeva OS, et al. Efficacy of bacteriophages in complex treatment of patients with burn wounds. Antibiot Khimioter 2001;46(1):10-4.

Le Goff A, Bunetel L, Mouton C, Bonnaure-Mallet M. Evaluation of root canal bacteria and their antimicrobial susceptibility in teeth with necrotic pulp. Oral Microbiol Immunol 1997;12(5):318-22.

Leonardo MR, Leal. JM. Endodontia: tratamento de canais radiculares. 2. ed. São Paulo: Panamericana; 1991.

Lima KC, Fava LRG, Siqueira Jr JF. Susceptibilities of Enterococcus faecalis biofilms to some antimicrobial medications. J Endod 2001;27(10):616-9.

Loeffler JM, Djurkovic S, Fischetti VA. Phage lytic enzyme Cpl-1 as a novel antimicrobial for pneumococcal bacteremia. Infect Immun 2003;71(11):6199-204.

Lopes HP, Siqueira Jr JF. Endodontia: biologia e técnica. Rio de Janeiro: Medsi; 1999.

Love RM. Enterococcus faecalis: a mechanism for its role in endodontic failure. Int Endod J 2001;34(5):399-405.

Lynne RE, Liewehr FR, West LA, Patton WR, Buxton TB, McPherson JC. In vitro antimicrobial activity of various medication preparations on Enterococcus faecalis in root canal dentin. J Endod 2003;29(3):187-90.

Mehl A, Folwaczny M, Haffner C, Hickel R. Bactericidal effects of $2.94 \mu \mathrm{m}$ Er: YAGLaser radiation in dental root canals. J Endod 1999;25(7):490-3.

Menezes MM, Valera MC, Jorge AOC, Koga-Ito CY, Camargo CHR, Mancini MNG. In vitro evaluation of the effectiveness of irrigants and intracanal medicaments on microorganisms within root canals. Int Endod J 2004;37(5):311-9.

Merril CR, Biswas B, Carlton R, Jensen NC, Creed GJ, Zullo S, et al. Long-circulating bacteriophage as antibacterial agents. Proc Natl Acad Sci USA 1996;93(8):3188-92.

Meyers CE, Walter EL, Green LB. Isolation of a bacteriophage specific for a Lactobacillus casei from human oral material. J Dent Res 1958;37(1):175-8. 
Miller WD. An introduction to the study of the bacterio-pathology of the dental pulp. Dent Cosmos 1894;36(7):505-28.

Molander A, Reit C, Dahlén G, Kvist T. Microbiological status of root-filled teeth with apical periodontitis. Int Endod J 1998;31(1):1-7.

Nair PNR, Sjögren U, Krey G, Kahnberg K, Sundqvist G. Intraradicular bacteria and fungi in root-filled, asymptomatic human teeth with terapy-resistant periapical lesions: a long-term light and electron microscopic follow-up study. J Endod 1990;16(12):5808.

Nakajo K, Komori R, Ishikawa S, Ueno T, Suzuki Y, Iwami Y, et al. Resistance to acidic and alkaline environments in the endodontic pathogen Enterococcus faecalis. Oral Microbiol Immunol 2006;21(5):283-8.

Nisengard RJ, Newman MG. Microbiologia oral e imunologia. 2.ed. Rio de Janeiro: Guanabara Koogan; 1997.

Oguntebi BR. Dentine tubule infection and endodontic therapy implications. Int Endod J 1994;27(4):218-22.

Oliveira DP, Barbizam VB, Trope M, Teixeira FB. In vitro antibacterial efficacy of endodontic irrigants against Enterococcus faecalis. Oral Surg Oral Med Oral Pathol Oral Radiol Endod 2007;103(5):702-6.

Ørstavik D, Haapasalo M. Disinfection by endodontic irrigants and dressings of experimentally infected dentinal tubules. Endod Dent Traumatol 1990;6(4):142-9.

Paisano AF, Spira B, Cai S, Bombana AC. In vitro antimicrobial effect of bacteriophages on human dentin infected with Enterococcus faecalis ATCC 29212. Oral Microbiol Immunol 2004;19(5):327-30.

Paiva JG, Antoniazzi JH. Endodontia. Bases para a prática clínica. 3. ed. São Paulo: Artes Médicas; 1993.

Paster BJ, Boches SK, Galvin JL, Ericson RE, Lau CN, Levanos VA, et al. Bacterial diversity in human subgingival plaque. J Bacteriol 2001;183(12):3770-83. 
Peciuliene V, Balciuniene I, Eriksen HM, Haapasalo M. Isolation of Enterococcus faecalis in previously root-filled canals in a lithuanian population. J Endod 2000;26(10):593-5.

Peciuliene V, Reynaud AH, Balciuniene I, Haapasalo M. Isolation of yeasts and enteric bacteria in root- filled teeth with chronic apical periodontitis. Int Endod J 2001;34(6):429-34.

Perepanova TS, Darbeeva OS, Kotliarova GA, Kondrat'eva EM, Măskaia LM, Malysheva VF, et al. The efficacy of bacteriophage preparations in treating inflammatory urologic diseases. Urol Nefrol 1995;5:14-7.

Perez F, Rochd T, Lodter JP, Calas P, Michel G. In vitro study of the penetration of three bacterial strains into root dentine. Oral Surg Oral Med Oral Pathol 1993;76(1):97-103.

Pinheiro ET, Gomes BPFA, Sousa ELR, Gadê-Neto CR, Souza-Filho FJ. Análise microbiológica de dentes com insucesso do tratamento endodôntico. Pesqui Odontol Bras 2000;14:152. Suplemento [Resumo SBPqO B356 ].

Pinheiro ET, Gomes BPFA, Ferraz CCR, Sousa ELR, Teixeira FB, Souza-Filho FJ. Microorganisms from canals of root-filled teeth with periapical lesions. Int Endod J 2003a;36(1):1-11.

Pinheiro ET, Gomes BPFA, Ferraz CCR, Teixeira FB, Zaia AA, Souza-Filho FJ. Evaluation of root canal microorganisms isolated from teeth with endodontic failure and their antimicrobial susceptibility. Oral Microbiol Immunol 2003b;18(2):100-3.

Portenier I, Haapasalo H, Rye A, Waltimo T, Ørstavik D, Haapasalo M. Inactivation of root canal medicaments by dentine, hydroxylapatite and bovine serum albumin. Int Endod J. 2001;34(3):184-8.

Portenier I, Haapasalo H, Ørstavik D, Yamauchi M, Haapasalo M. Inactivation of the antibacterial activity of iodine potassium iodide and chlorhexidine digluconate against Enterococcus faecalis by dentin, dentin matrix, type-1 collagen, and heat-killed microbial whole cells. J Endod 2002;28(9):634-7.

Portenier I, Waltimo T, Ørstavik D, Haapasalo M. The susceptibility of starved, stationary phase, and growing cells of Enterococcus faecalis to endodontic medicaments. J Endod 2005;31(5):380-6 
Portenier I, Waltimo T, Orstavik D, Haapasalo M. Killing of Enterococcus faecalis by MTAD and chlorhexidine digluconate with or without cetrimide in the presence or absence of dentine powder or BSA. J Endod 2006;32(2):138-41.

Radcliffe CE, Potouridou L, Qureshi R, Habahbeh N, Qualtrough A, Worthington H, et al. Antimicrobial activity of varying concentrations of sodium hypochlorite on the endodontic microorganisms Actinomyces israelii, A.naeslundii, Candida albicans and Enterococcus faecalis. Int Endod J 2004;37(7):438-46.

Regenmortel MHV, Fauquet CM, Bishop DHL, Carstens EB, Estes MK, Lemon SM, et al. Virus taxonomy: seventh report of the international committee on taxonomy of viruses (Virology Division International Union of Microbiological Societies) San Diego: Academic Press; 2000.

Safavi KE, Spångberg, LSW, Langeland K. Root canal dentinal tubule disinfection. J Endod 1990;16(5):207-10.

Sambrook J, Fritsch EF, Maniatis T. Molecular cloning : a laboratory manual. 2. ed. New York: Cold Spring Harbor; 1989.

Sakamoto M, Siqueira Jr JF, Roças IN, BennoY. Bacterial reduction and persistence after endodontic treatmant procedures. Oral Microbiol Immunol 2007;22:19-23.

Sena NT, Gomes BP, Vianna ME, Berber VB, Zaia AA, Ferraz CC, et al. In vitro antibacterial activity of sodium hypochorite and chlorhexidine against selected singlespecies biofilms. Int Endod J 2006;39(11):878-85.

Shabahang S, Torabinejad M. Effect of MTAD on Enterococcus faecalis contaminated root canals of extracted human teeth. J Endod 2003;29(9):576-9.

Shovelton DS. The presence and distribution of microorganisms within non-vital teeth. Br Dent J 1964;117(3):101-7.

Siqueira Jr JF, Uzeda M. Disinfection by calcium hydroxide pastes of dentinal tubules infected with two obligate and one facultative anaerobic bactéria. J Endod 1996;22(12):674-6. 
Siqueira Jr JF, Uzeda M, Fonseca MEF. A scanning electron microscopic evaluation of in vitro dentinal tubules penetration by selected anaerobic bacteria. $\mathrm{J}$ Endod 1996;22(6):308-10.

Siqueira Jr JF. Tratamento das infecções endodônticas. Rio de Janeiro: Medsi; 1997.

Siqueira Jr JF, Uzeda M. Intracanal medicaments : evaluation of the antibacterial effects of chlorhexidine, metronidazole, and calcium hydroxide associated with three vehicles. J Endod 1997;23(3):167-9.

Siqueira Jr JF, Machado AG, Silveira RM, Lopes HP, Uzeda M. Evaluation of the effectiveness of sodium hypochlorite used with three irrigation methods in the elimination of Enterococcus faecalis from the root canal, in vitro. Int Endod $\mathrm{J}$ 1997;30(4):279-82.

Siqueira Jr JF, Uzeda M. Influence of different vehicles on the antibacterial effects of calcium hydroxide. J Endod 1998;24(10):663-5.

Siqueira Jr JF, Rôças IN, Favieri A, Lima KC. Chemomechanical reduction of the bacterial population in the root canal after instrumentation and irrigation with $1 \%$, $2.5 \%$, and $5.25 \%$ sodium hypoclorite. J Endod 2000;26(6):331-4

Siqueira Jr JF, Paiva SSM, Rôças IN. Reduction in the cultivable bacterial populations in infected root canals by a chlorhexidine-based antimicrobial protocol. $J$ Endod 2007;33(5):541-7.

Sirén EK, Haapasalo MPP, Ranta K, Salmi P, Kerosuo ENJ. Microbiological findings and clinical treatment procedures in endodontic cases selected for microbiological investigation. Int Endod J 1997;30(2):91-5.

Sirén EK, Haapasalo MP, Waltimo TM, Ørstavik D. In vitro antibacterial effect of calcium hydroxide combined with chlorhexidine or iodine potassium iodide on Enterococcus faecalis. Eur J Oral Sci 2004;112(4):326-31.

Sjögren U, Fiador D, Persson S, Sundqvist G. Influence of infection at the time of root filling on the outcome of endodontics treatment of teeth with apical periodontitis. Int Endod J 1997;30(5):297-306. 
Slopek S, Durlakowa I, Weber-Dabrowska B, Dabrowski M, Kucharewicz-Krukowska A. Results of bacteriophage treatment of suppurative bacterial infections. III. Detailed evaluation of the results obtained in further 150 cases. Arch Immunol Ther Exp $1984 ; 32(3): 317-35$.

Smith HW, Huggins MB. Successful treatment of experimental Escherichia coli infections in mice using phage: its general superiority over antibiotics. J Gen Microb 1982;128(2):307-18.

Smith HW, Huggins MB. Effectiveness of phages in treating experimental Escherichia coli diarrhoea in calves, piglets and lambs. J Gen Microbiol 1983;129(8):2659-75.

Smith HW, Huggins MB, Shaw KM. The control of experimental Escherichia coli diarrhoea in calves by means of bateriophages. J Gen Microbiol 1987a;133(5):111126.

Smith HW, Huggins MB, Shaw KM. Factors influencing the survival and multiplication of bacteriophages in calves and their environment. J Gen Microbiol 1987b;133(5):1127-35.

Soares JA, Leonardo MR, Tanomaru-Filho M, Silva LA, Ito IY. Residual antibacterial activity of chlorhexidine digluconate and camphorated p-monochlorophenol in calcium hydroxide-based root canal dressings. Braz Dent J 2007;18(1):8-15.

Spratt DA, Pratten J, Wilson M, Gulabivala K. An in vitro evaluation of the antimicrobial efficacy of irrigants on biofilms of root canal isolates. Int Endod $\mathrm{J}$ $2001 ; 34(4): 300-7$.

Sulakvelidze A, Alavidze Z, Morris Jr JG. Bacteriophage therapy. Antimicrob Agents Chemother 2001;45(3):649-59.

Sulakvelidze A, Morris Jr JG. Bacteriophages as therapeutic agents. Ann Med 2001;33(8):507-9.

Sunde PT, Olsen I, Debelian GJ, Tronstad L. Microbiota of periapical lesions refractory to endodontic therapy. J Endod 2002;28(4):304-10.

Sundqvist G. Associations between microbial species in dental root canal infections. Oral Microbiol Immunol 1992a;7(5):257-62. 
Sundqvist G. Ecology of the root canal flora. J Endod 1992b;18(9):427-30.

Sundqvist G, Figdor D, Persson S, Sjögren U. Microbiologic analysis of teeth with failed endodontic treatment and outcome of conservative re-treatment. Oral Surg Oral Méd Oral Pathol 1998;85(1):86-93.

Tortora GJ, Funke BR, Case CL. Microbiologia. $6^{\text {a }}$ ed. Porto Alegre: Artes Médicas; 2000.

Trope, M, Delano EO, Ørstavik D. Endodontic treatment of teeth with apical periodontitis: single vs. multivisit treatment. J Endod 1999;25(5):345-53.

Tylenda CA, Calvert C, Kolenbrander PE, Tylenda A. Isolation of Actinomyces bacteriophage from human dental plaque. Infect Immun 1985;49(1):1-6.

Vivacqua-Gomes N, Gurguel-Filho, Gomes BPFA, Ferraz CCR, Zala AA, SouzaFilho FJ. Recovery of Enterococcus faecalis after single-or multiple-visit root canal treatments carried out in infected teeth ex vivo. Int Endod J 2005;38(10):697-704.

Wakabayashi H, Morita S, Koba K, Tachibana H, Matsumoto. Effect of calcium hydroxide paste dressing on uninstrumented root canal wall. J Endod 1995;21(11):543-5.

Waltimo TMT, Ørstavik D, Sirén EK, Haapasalo MPP. In vitro yeast infection of human dentin. J Endod 2000;26(4):207-9.

Wittgow Jr WC, Sabiston Jr CB. Microorganisms from pulpal chambers of intact teeth with necrotic pulps. J Endod 1975;1(5):168-71.

Yesilsoy C, Whitaker E, Cleveland D, Phillips E, Trope M. Antimicrobiol and toxic effects of established and potential root canal irrigants. J Endod 1995;21(10):513-5.

Zerella JA, Fouad AF, Spångberg LSW. Effectiveness of a calcium hydroxide and chlorhexidine digluconate mixture as disinfectant during retreatment of failed endodontic cases. Oral Surg Oral Med Oral Pathol Oral Radiol Endod 2005;100(6):756-61.

Zierdt $\mathrm{CH}$. Preservation of staphylococcal bacteriophage by means of lyophilization. Am J Clin Pathol 1959;31(4):326-31. 
Zierdt $\mathrm{CH}$. Stabilities of lyophilized Staphylococcus aureus typing bacteriophages. Appl Environ Microbiol 1988;54(10):2590. 
APÊNDICE - Produtos comerciais a base de fagos

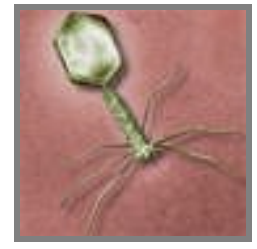

Em uma revisão da literatura publicada por Sulakvelidze, Alavidze e Morris Jr (2001), os autores analisam a fagoterapia e descrevem como surgiram os primeiros medicamentos à base de fagos.

Poucos anos depois da descoberta dos fagos, um laboratório em Paris, pertencente a um de seus descobridores, Felix d'Herelle, já produzia pelo menos cinco compostos à base de fagos chamados Bacté-coli-phage, Bacté-rhino-phage, Bacté-intesti-phage, Bacté-pyo-phage e Bacté-staphy-phage. Esses produtos preparados para o controle de diversas infecções bacterianas em seres humanos, eram comercializados pela empresa que originou a L'Oréal, companhia mundialmente conhecida nos dias de hoje. A terapêutica com fagos foi adotada também nos EUA e produzia medicações à base de fagos contra Staphylococcus, Streptococcus, Escherichia coli e outros patógenos (Eli Lilly Company - Indianapolis, Ind), tanto na forma de solução como em forma de gel. Esses produtos eram usados em diferentes tipos de infecção, incluindo abscessos, feridas supurativas, vaginites, e infecções agudas ou crônicas do trato respiratório.

Apesar da interrupção das pesquisas em fagoterapia, os países do Leste Europeu e a antiga União Soviética continuaram a pesquisar e a utilizar tais fármacos.

O responsável pela maior parte das pesquisas clínicas, o Instituto Eliava de Bacteriologia, Microbiologia e Virologia, localizado em Tbilise, Georgia, já chegou a 
empregar 1.200 pesquisadores e a produzir milhares de medicações à base de fagos por dia, contra as mais diferentes bactérias.

Outro instituto, o Hirszfeld, localizado em Varsóvia (Polônia), também participa do desenvolvimento da fagoterapia desde 1957. Seu laboratório já produziu compostos para o tratamento de infecções por Shigella, septicemia, furunculose, e infecções do trato respiratório e urinário, bem como para casos de infecções refratárias aos tratamentos convencionais com antibióticos em seres humanos.

"As ciências têm as raízes amargas, mas os frutos são doces." 


\section{UNIVERSIDADE DE SÃO PAULO FACULDADE DE ODONTOLOGIA}

\section{PARECER DE APROVAÇÃO Protocolo 125/07}

O grupo de trabalho indicado pelo Comitê de Ética em Pesquisa APROVOU o protocolo de pesquisa "ESTUDO IN VITRO DA AÇÃO ANTIMICROBIANA DE BACTERIÓFAGOS ESPECIFICOS EM CANAIS RADICULARES INFECTADOS POR ISOLADOS CLÍNICOS DE Enterococcus faecalis", de responsabilidade da Pesquisadora ADRIANA FERNANDES PAISANO, sob orientação do Professor Doutor ANTONIO CARLOS BOMBANA.

Tendo em vista a legislação vigente, devem ser encaminhados a este Comitê relatórios anuais referentes ao andamento da pesquisa e ao término cópia do trabalho em "cd". Qualquer emenda do projeto original deve ser apresentada a este CEP para apreciação, de forma clara e sucinta, identificando a parte do protocolo a ser modificada e suas justificativas.

São Paulo, 04 de outubro de 2007

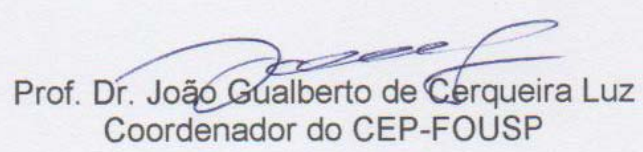

Av. Prof. Lineu Prestes, 2227 - Cidade Universitária "Armando de Salles Oliveira" CEP 05508-900 Säo Paulo - SP - Diretoria Telefax: (011) 3091- 0062/3091-7817/3091-7860 - Compras (011) 3091-7895 Impresso no S.D.O. 
ANEXO B - Meio de cultura Luria-Bertani (LB)

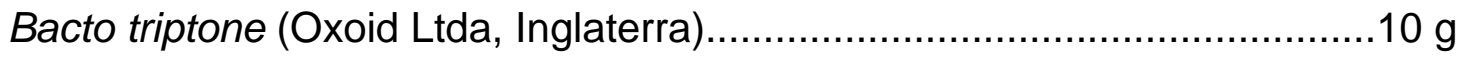

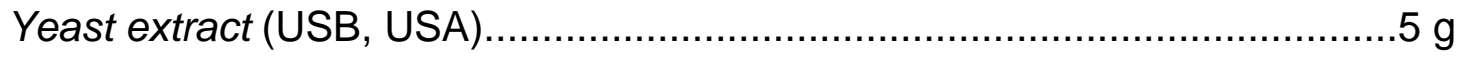

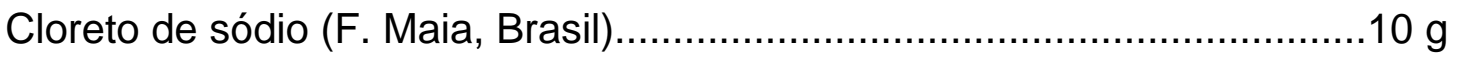

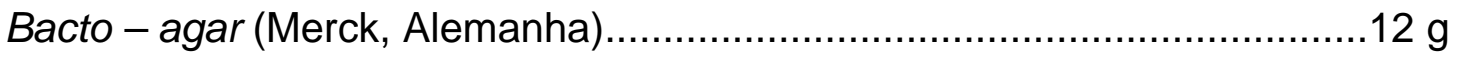

Dissolver o conteúdo acima em $900 \mathrm{~mL}$ de água destilada, ajustando-se o pH para 7.4 com aproximadamente $250 \mu \mathrm{l}$ de $10 \mathrm{M} \mathrm{NaOH}$. Completar o volume para um litro. Esterilizar a $121^{\circ} \mathrm{C}$ durante 15 minutos. Quando usado no preparo do inóculo, foi acrescentado cloreto de cálcio a dez milimolar (mM).

Para ágar LB, acrescentar $20 \mathrm{~g}$ de Agar-agar Purified and Free (Merck, Alemanha) por litro. 
ANEXO C - Tryptic soy broth (TSB)

Fórmula (g/L), pH final $=7,3+/-0,2$ a $25{ }^{\circ} \mathrm{C}$

Bacto tryptone

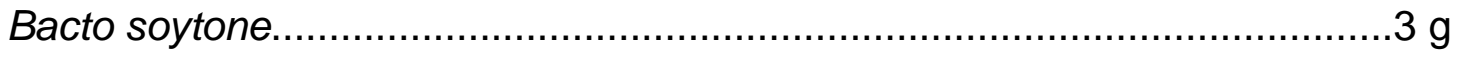

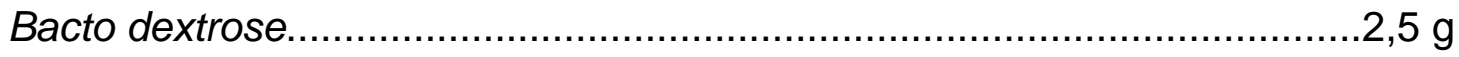

Cloreto de sódio................................................................................ $\mathrm{g}$

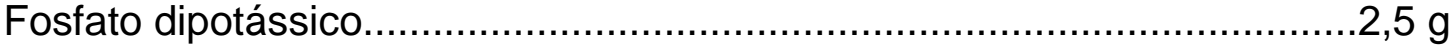

Em balança analítica pesar $30 \mathrm{~g}$ de TSB, transferir para Erlenmeyer acrescido de $1000 \mathrm{~mL}$ de água destilada, e deixar hidratar por 10 a 15 minutos. Com o auxílio de um bastão de vidro dissolver o pó completamente. Esterilizar em autoclave a 121 ${ }^{0} \mathrm{C}$, por 15 minutos. 
ANEXO D - Meio de cultura top-agar

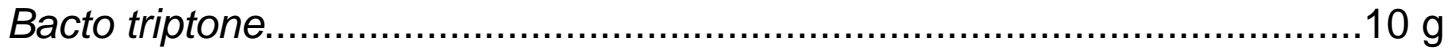

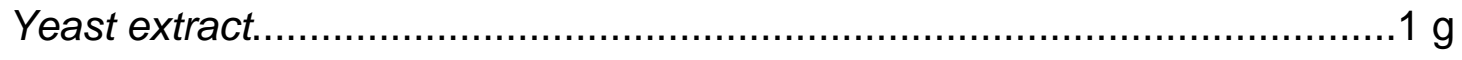

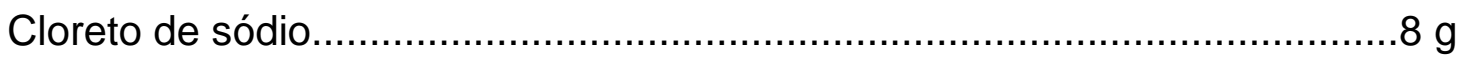

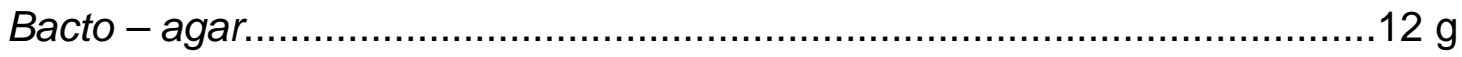

Adicionar em um litro de água destilada $10 \mathrm{~g}$ de Tryptone (Oxoid Ltda, Inglaterra), $1 \mathrm{~g}$ de Yeast Extract Powder Ultrapure (USB, USA) e $8 \mathrm{~g}$ de $\mathrm{NaCl}$ (F. Maia, Brasil). Após esterilização a $121^{\circ} \mathrm{C}$ durante 15 minutos, adicionar $2 \mathrm{~mL}$ de $1 \mathrm{M}$ $\mathrm{CaCl}_{2}$ e $5 \mathrm{~mL}$ de glicose a 20\%. Acrescentar $12 \mathrm{~g}$ de Agar-agar Purified and Free (Merck, Alemanha) por litro de meio. 
ANEXO E - Tryptic soy agar (TSA)

Fórmula (g/L), pH fina I= 7,3 +/- 0,2 a $25{ }^{\circ} \mathrm{C}$

Bacto tryptone

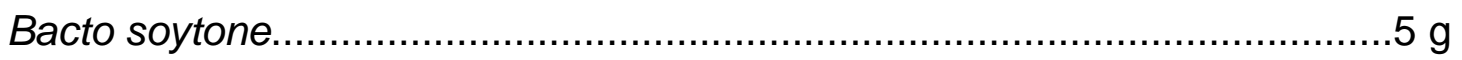

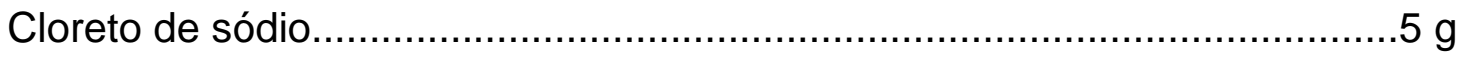

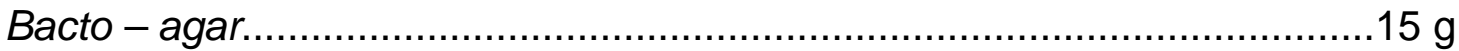

Em balança analítica, pesar 40,0 g de TSA, transferi-los para Erlenmeyer acrescido de $1000 \mathrm{~mL}$ de água destilada, e deixar hidratar por 10 a 15 minutos. Com o auxílio de um bastão de vidro dissolver o pó completamente. Fechar o frasco e esterilizar em autoclave a $121{ }^{\circ} \mathrm{C}$, por 15 minutos. Em seguida distribuir em placas do tipo Petri. 
ANEXO F - Solução de fosfotungstato de potássio a $2 \%$

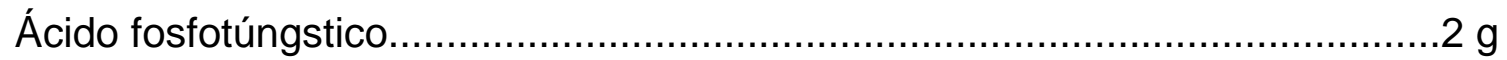

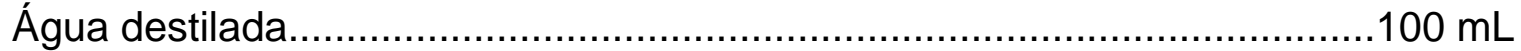

Dissolver o reagente em água destilada e corrigir seu $\mathrm{pH}$ para 6,4 com $\mathrm{KOH}$ 1M (neutralizado por hidróxido de sódio). Armazenar em frasco escuro a $4^{\circ} \mathrm{C}$. 
ANEXO G - Meio de cultura EVA

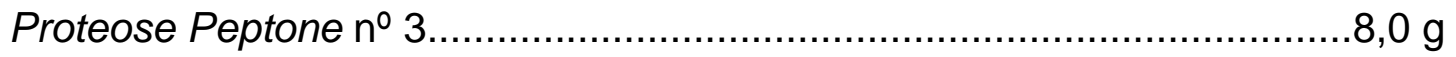

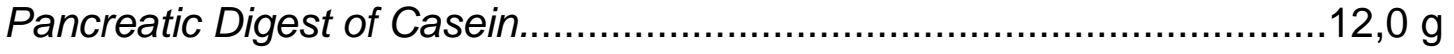

Dextrose

Dipotassium Phosphate................................................................. $2,7 \mathrm{~g}$

Monotassium Phosphate................................................................ $2,7 \mathrm{~g}$

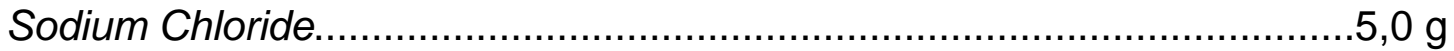

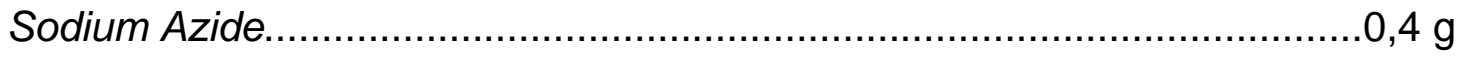

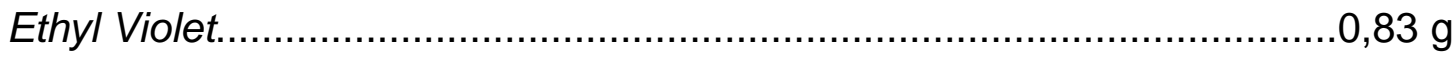

Em balança analítica, pesar 35,8 g de TSB, transferir para Erlenmeyer acrescido de $1000 \mathrm{~mL}$ de água destilada, deixar hidratar por 10 a 15 minutos. Com o auxílio de um bastão de vidro dissolver o pó completamente. Fechar o frasco e esterilizar em autoclave a $121{ }^{\circ} \mathrm{C}$, por 15 minutos. 
ANEXO H - Solução de formvar a 1\%

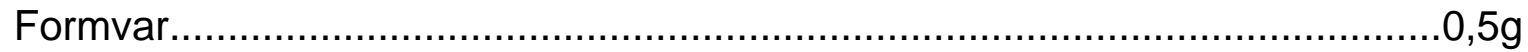

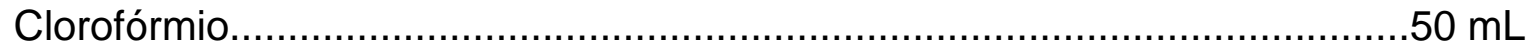

Dissolver o conteúdo acima em $50 \mathrm{~mL}$ de clorofórmio e deixar repousar pelo menos 24 horas antes do uso para homogeneizar. Armazenar em temperatura ambiente. 
ANEXO I - Solução Tris-Cl (1 M)

Dissolver 121,1 g de Tris em $800 \mathrm{~mL}$ de água destilada e ajustar o pH com a adição de $\mathrm{HCl}$ (para pH 8,0, deve-se acrescentar $42 \mathrm{~mL}$ ). 
ANEXO J - Solução de TAE

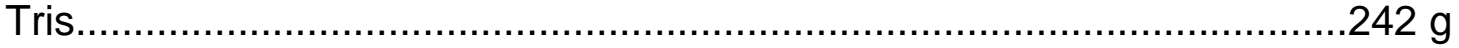

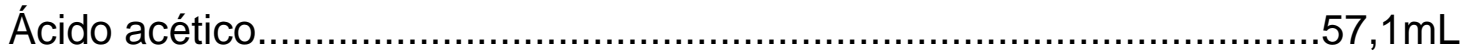

EDTA 0,5 M........................................................................ 
ANEXO K - Solução TE pH 8.0

Solução composta por 100 mM de Tris-Cl (pH 8,0) e 10 mM de EDTA (ph 8,0). Deve ser autoclavada por 10 minutos (15 psi) e armazenada em temperatura ambinte. 
ANEXO L - Solução TES

Solução composta por 10 mM de Tris-Cl (pH 7,5), 1 mM de EDTA (ph 7,5) e SDS a $1 \%(w / v)$. Deve ser armazenada em temperatura ambinte. 
ANEXO M - llustração de taxonomia dos bacteriófagos (ACKERMANN et al., 1997)
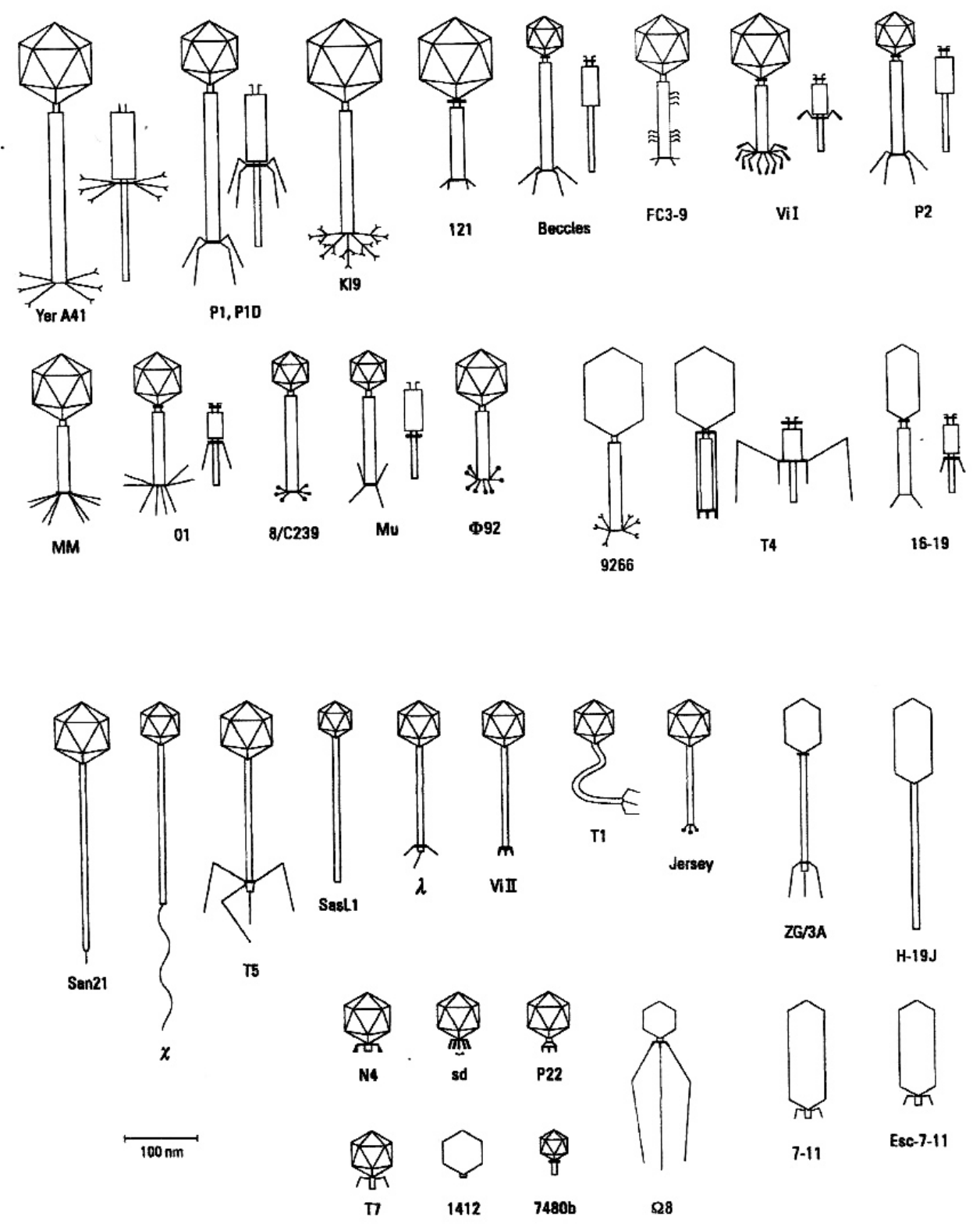
"Entenda que princípios e convicções fechadas podem ser um grande peso, a trave do movimento e da busca." 